Российская Академия Естествознания

Издательский дом Академии Естествознания

\title{
ПОДГОТОВКА УЧИТЕЛЕЙ И СТУДЕНТОВ К ИННОВАЦИОННЫМ ПРОЦЕССАМ В РЕАЛИЗАЦИИ ФЕДЕРАЛЬНЫХ ГОСУДАРСТВЕННЫХ ОБРАЗОВАТЕЛЬНЫХ СТАНДАРТОВ
}

\author{
Коллективная монография
}

\author{
Рекомендовано УМО РАЕ \\ по классическому университетскому \\ и техническому образованию в качестве \\ учебного пособия для студентов \\ высших учебных заведений, \\ обучающихся по специальностям: \\ 44.03.01 - «Педагогическое образование»; \\ 44.03 .05 - «Педагогическое образование»
}


УДК 378.147.88

ББК 74.26

П44

\section{Рецензенты:}

Шумилова Е.А. - доктор педагогических наук, зав. кафедрой педагогики и психологии Челябинского государственного педагогического университета;

Пикатова Н.Б. - кандидат педагогических наук, директор МБОУ СОШ № 115 г. Челябинска

Подготовка учителей и студентов к инновационным процесП44 сам в реализации Федеральных государственных образовательных стандартов: коллективная монография / Н.А. Белоусова, Е.В. Григорьева, В.В. Дрозина, Н.В. Мамылина, Л.Г. Махмутова, Е.В. Осолодкова, Н.Н. Титаренко, М.А. Худякова. - М.: Издательский дом Академии Естествознания, 2015. - 176 с.

\section{ISBN 978-5-91327-351-2}

\section{DOI: $10.17513 / \mathrm{np} .129$}

Монография освещает теоретические и практические аспекты инноваций в реализации Федеральных государственных стандартов. Настоящая монография поможет творчески работающим учителям осмыслить и дополнить недостающие компоненты целостных инновационных подходов в реализации стандарта образования. Студенты педагогических вузов могут воспользоваться этим изданием для эффективной подготовки к практической деятельности.

ISBN 978-5-91327-351-2
(C) Белоусова Н.А., Григорьева Е.В., Дрозина В.В., Мамылина Н.В., Махмутова Л.Г., Осолодкова Е.В., Титаренко Н.Н., Худякова М.А., 2015

(c) ИД «Академия Естествознания»

(C) МОО «Академия Естествознания» 


\section{ВВЕДЕНИЕ}

Современная образовательная система находится в состоянии инновационных изменений, направленных на достижение нового качества образования. Концепция модернизации образования определяет основные приоритетные направления, такие как обновление целей и содержания образования, методов и технологий обучения.

Инновации, как результат научных поисков и передового педагогического опыта, являются наиболее оптимальным средством повышения эффективности образования и отражены в содержании реализуемого в России стандарта образования. Статья 11 закона «Об образовании» устанавливает базовые требования к федеральным государственным образовательным стандартам, это не только единство образовательного пространства РФ, преемственность основных образовательных программ, государственные гарантии уровня и качества образования на основе единства обязательных требований к условиям реализации основных образовательных программ и результатам их освоения, но и вариативность содержания образовательных программ соответствующего уровня образования, возможность формирования образовательных программ различного уровня сложности и направленности с учетом образовательных потребностей и способностей обучающихся.

Поскольку содержание образования (конкретные образовательные программы образовательных организаций), должно соответствовать требованиям стандартов, стандарт является эффективным инструментом регулирования требований к содержанию образования.

В практической деятельности не достаточно разработаны не только содержание образовательных программ, но и контрольно-измерительные материалы, позволяющие оценивать результативность деятельности учителей и обучающихся. Требуют глубокого анализа методические аспекты успешной реализации содержания стандарта. 
Инновационные процессы в обществе и образовании существуют не изолированно друг от друга, а взаимодействуют между собой. Эта тенденция обусловлена интеграционными процессами в науке, в формировании современного стиля научного мышления человека и интеграционными процессами в самом образовании. Стандарт образования в первую очередь направлен на формирование нового стиля мышления и когнитивных возможностей человека будущей эпохи.

В настоящее время в практике общеобразовательных и профессиональных учебных заведений присутствуют лишь элементы педагогических инноваций. Настоящая монография поможет творчески работающим учителям осмыслить и дополнить недостающие компоненты целостных инновационных подходов в реализации стандарта образования, а также будет полезна студентам педагогических вузов. Материалы коллективной монографии раскрывают теоретические и практические подходы к реализации стандарта.

От авторского коллектива

Н.А. Белоусова 


\title{
ГДава. 1. ПРАКТИЧЕСКАЯ МЕТОДОЯОГИЯ РЕАДИЗАЦИИ ФЕДЕРАЯЬНЫХ ГОСУДАРСТВЕННЫХ СТАНДАРТОВ
}

\author{
РАЗРАБОТКА И АПРОБАЦИЯ ИННОВАЦИОННОГО \\ ИНСТРУМЕНТАРИЯ ОЦЕНКИ ПЛАНИРУЕМЫХ РЕЗУЛЬТАТОВ \\ НАЧАЛЬНОГО ОБЩЕГО ОБРАЗОВАНИЯ В ЧАСТИ УЧЕТА \\ РЕГИОНАЛЬНЫХ И ЭТНОКУЛЬТУРНЫХ ОСОБЕННОСТЕЙ \\ ЧЕЛЯБИНСКОЙ ОБЛАСТИ
}

Н.Н. Титаренко

Для оценки качества реализации федерального государственного образовательного стандарта начального общего образования все школы России ориентированы на процесс овладения младшими школьниками планируемыми результатами образования, что, в свою очередь, требует разработки принципиально нового диагностического инструментария, который не использовался ранее школьными учителями. Например, нет инструментов и вариантов моделей КИМов для оценки достижений младшими школьниками планируемых результатов в части учета региональных и этнокультурных особенностей конкретных регионов. О необходимости таких инструментов свидетельствуют апробируемые в пилотных школах Челябинской области методические рекомендации для разработки общеобразовательными учреждениями основных образовательных программ начального, основного, среднего (полного) образования на основе учета национальных, региональных и этнокультурных особенностей региона [2]. Что касается начального общего образования, то по итогам образования младшие школьники будут участвовать в мониторинге по проверке освоения планируемых результатов начального общего образования в части учета региональных и этнокультурных особенностей Челябинской области.

Целью нашей работы является разработка модели инструментария оценки результатов освоения младшими школьниками основной образовательной программы в части учёта региональных и этнокультурных особенностей Челябинской области.

Направления и тематика контрольно-измерительных материалов (далее КИМ) определены соответственно смысловому наполнению содержательного компонента основной образовательной программы 
с учетом региональных и этнокультурных особенностей региона. На уровне начального общего образования - это первоначальные представления и опыт знакомства с региональным и этнокультурным многообразием Челябинской области (когнитивный аспект), понимание своей национальной и этнической принадлежности, уважительное отношение к истории и культуре других народов, проживающих на территории области (ценностно-смысловой аспект), отражение участия младших школьников Челябинской области в школьных и внешкольных мероприятиях (деятельностный аспект).

Тематика КИМов основана на содержании основной образовательной программы образовательной организации. По региональному направлению это темы краеведческого характера, например: «Достопримечательности Челябинской области», «Заповедники и национальные парки Челябинской области», «Озера Южного Урала», «Города Челябинской области» и другие. По этнокультурному направлению она представлена такими темами, как «Национальные музыкальные инструменты», «Национальная кухня», «Национальные украшения народов Урала», «Национальные игры и танцы», «Национальные костюмы народов Урала» и другие (табл. 1).

Таблица 1

Тематика контрольных измерительных материалов

\begin{tabular}{|l|l|}
\hline \multicolumn{1}{|c|}{ Этнокультурное направление } & \multicolumn{1}{|c|}{ Региональное направление } \\
\hline $\begin{array}{l}\text { Национальные музыкальные инстру- } \\
\text { менты народов Челябинской области }\end{array}$ & $\begin{array}{l}\text { Заповедники и национальные парки } \\
\text { Челябинской области }\end{array}$ \\
\hline $\begin{array}{l}\text { Национальные украшения народов } \\
\text { Урала }\end{array}$ & Города Челябинской области \\
\hline Национальные игры народов Урала & Озера Южного Урала \\
\hline $\begin{array}{l}\text { Национальные костюмы народов } \\
\text { Южного Урала }\end{array}$ & Древесные растения Южного Урала \\
\hline Национальная кухня народов Урала & Полезные ископаемые Южного Урала \\
\hline Национальные танцы народов Урала & Горные хребты Южного Урала \\
\hline Национальный быт Урала & Времена года на Южном Урале \\
\hline $\begin{array}{l}\text { Образ Снегурочки народов Южного } \\
\text { Урала }\end{array}$ & Животные Южного Урала \\
\hline $\begin{array}{l}\text { Весенний праздник татарского и баш- } \\
\text { кирского народов }\end{array}$ & $\begin{array}{l}\text { Краеведческий музей Челябинской } \\
\text { области }\end{array}$ \\
\hline $\begin{array}{l}\text { Устное народное творчество народов } \\
\text { Южного Урала }\end{array}$ & $\begin{array}{l}\text { Достопримечательности Саткинского } \\
\text { района Челябинской области }\end{array}$ \\
\hline
\end{tabular}


Таким образом, контрольно-измерительные материалы для начального общего образования должны быть разработаны в соответствии с требованиями к результатам освоения основной образовательной программы в части учета региональных и этнокультурных особенностей территории и предложены для выполнения выпускникам начальной школы, обучающимся по ФГОС НОО. При разработке модели КИМов Титаренко Натальей Николаевной были учтены вышеперечисленные условия.

Структура модели КИМов разработана нами в виде двух комплексных работ регионального и этнокультурного компонентов, и двух мини-проектов по той же тематике на выбор обучающегося. Задания в работах нацелены на определение уровня освоенности обучающимися содержания ООП HOO с учётом региональных и этнокультурных особенностей (рис. 1).
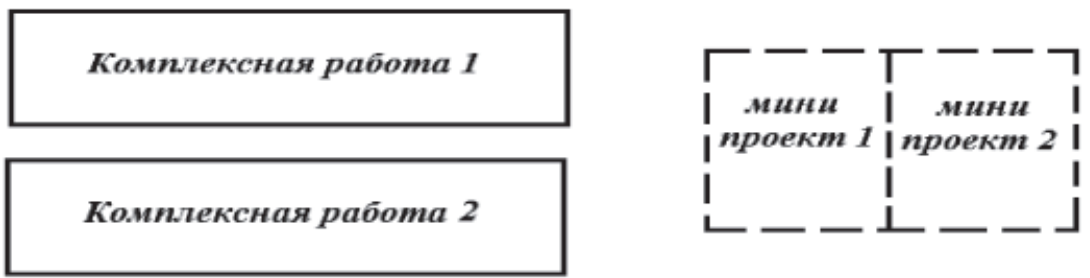

Рис. 1. Модель инструментария по оценке результатов освоения младшими школьниками основной образовательной программы в части учёта региональных и этнокультурных особенностей территории

Опишем структурно-функциональные особенности элементов структуры модели КИМов: комплексной работы и мини-проекта.

Комплексная работа включает несплошной текст и четыре задания к нему. Разработанная нами конструкция несплошного текста (сочетание текстовой и внетекстовой информации) обеспечивает школьнику необходимый уровень представления о региональных или этнокультурных особенностях Челябинской области по определенной теме. Количество слов в тексте для учеников четвертого класса, по нашему мнению, не должно превышать 150 слов, что дает возможность прочитать и осознать содержание текста в течение 3-4 минут. В сюжет текста мы предлагаем включать не более трех сравниваемых параметров, что достаточно для аналитических возможностей младших школьников. Кроме того, сюжетом КИМов может явиться описание реального культурно-познавательного события из внеурочной жизни школьников области: подготовка или проведение праздников, конкурсов, выставок, походов, экскурсий и т. п. Мы уверены, что такой подход к выбору значимых 
событий способствует не только развитию познавательного интереса младших школьников, но и может мотивировать участвовать в жизни ближайшего социокультурного окружения.

Вторым важным источником информации являются изображения, которые иллюстрируют некоторые факты содержания текста и сами несут дополнительную визуальную необходимую информацию. Таким образом, использование текстовой информации и изображений позволяет предложить обучающимся достаточный содержательный резерв для выполнения заданий и, что крайне важно, несет воспитательные эффекты.

Задания, включенные нами в комплексную работу, составлены на основе ситуаций, взятых из учебной и внеурочной деятельности школьников, представлены в форме учебно-познавательных и учебно-практических задач.

Задание № 1 закрытого типа с выбором одного правильного ответа, направленное на выявление сформированности умений понимать информацию, представленную разными способами: словесно, в виде таблицы, схемы, диаграммы, рисунка. Задание предложено на когнитивный аспект, проверяет уровень представлений. Обучающемуся необходимо выбрать правильный ответ из трех предлагаемых вариантов, два из которые являются неверными, т. е. дистракторами. Дистрактор (отвлекающий ответ) - вариант ответа на тестовое задание закрытого типа, похожий на правильный, но не являющийся таковым. В первом задании используются два дистрактора. Чтобы принять решение при выборе ответа, обучающийся должен прочитать текст комплексной работы и рассмотреть изображения, только такая полная информация обеспечит верный выбор.

Задачная формулировка ясная и короткая, глаголы указывают школьнику точные действия. Краткость обеспечивается тщательным подбором слов, иллюстраций, позволяющих минимумом средств добиваться максимума ясности смысла задания.

Задание № 2 открытого типа со свободным развернутым ответом, направленное на выявление сформированности у обучающихся умений анализировать, сопоставлять, интерпретировать и обобщать информацию, содержащуюся в разных частях текста, представленную в различной форме. Причем школьник должен сформулировать и записать ответ с учетом предусмотренных в задании ограничений. Задание предложено на когнитивный аспект, проверяет уровень представлений.

Задание № 3 закрытого типа с выбором одного правильного ответа, направленное на выявление сформированности умения в процессе работы с одним или несколькими источниками выявлять достоверную или 
противоречивую информацию. Только после чтения текста и сравнивания вариантов ответа с информацией в тексте школьник может выбрать верный вариант ответа. Задание предложено на когнитивный аспект, проверяет уровень представлений школьника.

Задание № 4 открытого типа со свободно конструируемым ответом, направленное на выявление сформированности у обучающихся умения на основе имеющихся знаний, жизненного опыта находить пути восполнения недостающей информации. Задание предложено на ценностносмысловой аспект. Школьнику необходимо сформулировать и записать аргументы, откликнуться на значимое событие, осмыслить и представить свою позицию.

Таким образом, школьнику предлагается выполнить по четыре задания двух блоков регионального и этнокультурного компонентов.

Далее школьнику предстоит изучить два варианта мини-проектов, определиться со своими возможностями в их успешном выполнении и принять решение, какой из них будет выполнен.

Мини-проект позволяет проверить сформированность у обучающихся умений использовать информацию из текста для решения различного круга учебно-познавательных и учебно-практических задач без привлечения или с привлечением дополнительных знаний и личного опыта обучающихся, развивает продуктивно-творческое мышление обучающих. Экспертной оценке подлежит также соответствие подготовленного продукта (проекта) требованиям задания, продемонстрированные умения отбирать и преобразовывать информацию, пользоваться избыточной информацией, планировать последовательность действий, принимать решения, контролировать полноту выполнения действий, указанных в задачной формулировке.

Можно констатировать, что задания к несплошному тексту представляют собой учебно-познавательные и учебно-практические задачи, в одних их которых обучающимся предлагается сделать выбор одного правильного ответа из трех предложенных, в других - написать свой ответ в указанном месте. Объектами оценивания при выполнении заданий являются метапредметные и предметные результаты обучающихся. Подробная характеристика заданий к несплошному тексту представлена ниже в табл. 2.

Приведем два варианта комплексных работ и мини-проектов для проверки результатов освоения выпускниками начальной школы основной образовательной программы в части учёта этнокультурных и региональных особенностей Челябинской области по теме «Национальные музыкальные инструменты» и »Краеведческий музей Челябинской области». 
Таблица 2

Характеристика заданий к несплошному тексту КИМ

\begin{tabular}{|c|c|c|c|}
\hline $\begin{array}{l}\text { Номер } \\
\text { задания }\end{array}$ & $\begin{array}{c}\text { Объект оценивания: } \\
\text { метапредметный результат }\end{array}$ & $\begin{array}{l}\text { Объект оценивания: } \\
\text { предметный результат }\end{array}$ & $\begin{array}{c}\text { Оценочный } \\
\text { критерий } \\
\text { задания }\end{array}$ \\
\hline 1 & $\begin{array}{l}\text { понимать информацию, пред- } \\
\text { ставленную разными способа- } \\
\text { ми: словесно, в виде таблицы, } \\
\text { схемы, диаграммы, рисунка }\end{array}$ & \multirow{3}{*}{$\begin{array}{l}\text { первоначальные пред- } \\
\text { ставления об этниче- } \\
\text { ской принадлежности, } \\
\text { национальных цен- } \\
\text { ностях, традициях, } \\
\text { культуре народов } \\
\text { и этнических групп, } \\
\text { проживающих на тер- } \\
\text { ритории региона }\end{array}$} & \multirow[t]{3}{*}{$\begin{array}{l}\text { когнитив- } \\
\text { ный }\end{array}$} \\
\hline 2 & $\begin{array}{l}\text { сопоставлять и обобщать со- } \\
\text { держащуюся в разных частях } \\
\text { текста информацию }\end{array}$ & & \\
\hline 3 & $\begin{array}{l}\text { в процессе работы с одним или } \\
\text { несколькими источниками вы- } \\
\text { являть достоверную (противо- } \\
\text { речивую) информацию }\end{array}$ & & \\
\hline 4 & $\begin{array}{l}\text { на основе имеющихся знаний, } \\
\text { жизненного опыта находить } \\
\text { пути восполнения недостаю- } \\
\text { щей информации }\end{array}$ & $\begin{array}{l}\text { понимание своей на- } \\
\text { циональной и этниче- } \\
\text { ской принадлежности; } \\
\text { уважительное отноше- } \\
\text { ние к истории и куль- } \\
\text { туре других народов } \\
\text { и этнических групп, } \\
\text { проживающих на тер- } \\
\text { ритории региона }\end{array}$ & $\begin{array}{l}\text { ценностно- } \\
\text { смысловой }\end{array}$ \\
\hline $\begin{array}{c}5 \\
\text { твор- } \\
\text { ческий } \\
\text { мини- } \\
\text { проект }\end{array}$ & $\begin{array}{l}\text { формулировать собственное } \\
\text { мнение и позицию }\end{array}$ & $\begin{array}{l}\text { участие в школьных } \\
\text { и внешкольных ме- } \\
\text { роприятиях социаль- } \\
\text { но-ориентированного } \\
\text { характера, в том числе } \\
\text { отражающих нацио- } \\
\text { нальные, региональ- } \\
\text { ные и этнокультурные } \\
\text { особенности }\end{array}$ & $\begin{array}{l}\text { деятель- } \\
\text { ностный }\end{array}$ \\
\hline
\end{tabular}

Комплексная работа:

национальные музыкальные инструменты (этнокультурные особенности)

Школьники лицея № 10 города Челябинска учились играть на национальных инструментах народов Челябинской области и в мае 2014 года решили провести школьный музыкальный праздник. На 
балалайке русские мелодии будет играть Иван, на мандолине татарские мелодии репетирует Альфия, на курае башкирскую музыку исполнит Марат.
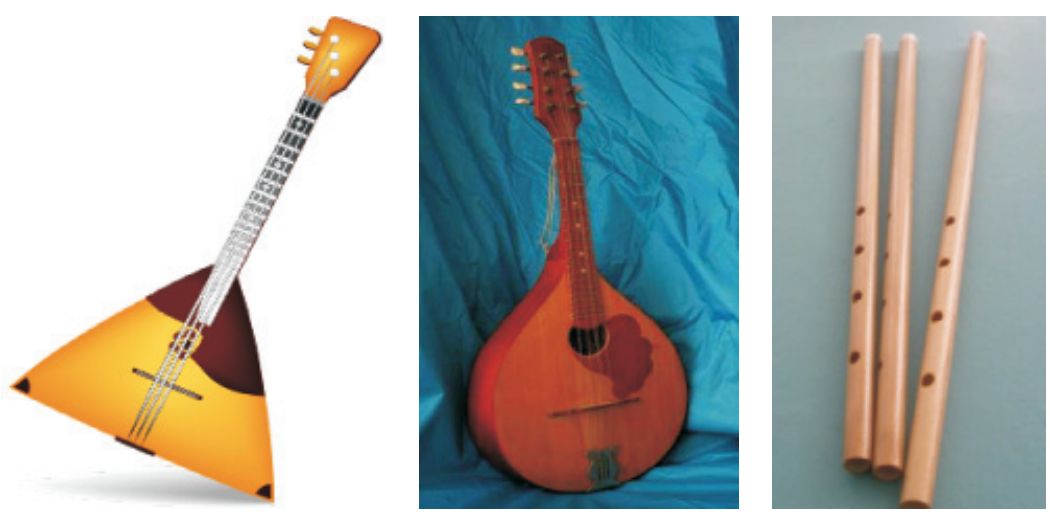

\section{Задания:}

1. Рассмотри изображение балалайки. Отметь знаком + ее описание.

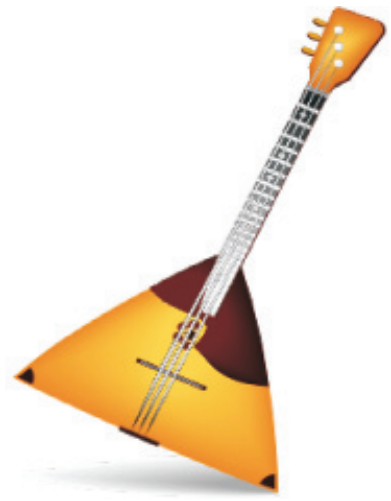

$\square$ духовой музыкальный инструмент в виде трубки с отверстиями длиной от 120 мм;

$\square$ струнный щипковый музыкальный инструмент с овальной формой тела небольшого размера и пятью двойными струнами;

$\checkmark$ трехструнный щипковый музыкальный инструмент с треугольной формой тела. 
2. Для подготовки к викторине в школе составь и допиши задания:

\begin{tabular}{|c|l|}
\hline \multicolumn{1}{|c|}{ Задания викторины } & Название \\
\hline $\begin{array}{l}\text { Это русский народный трехструнный щипковый музы- } \\
\text { кальный инструмент с треугольной формой тела. }\end{array}$ & балалайка \\
\hline Это & курай \\
\hline Это & мандолина \\
\hline
\end{tabular}

3. Отметь знаком + мероприятие, которое пройдет в лицее № 10. национальные инструменты татар национальные инструменты народов Челябинской области школьный музыкальный праздник

4. На сайте школы ученики пишут объявление для родителей с приглашением на музыкальный праздник. Напиши два аргумента, почему гостям стоит прийти на праздник.

1) смогут увидеть и услышать три разных музыкальных инструмента, 2)

3)

\section{Мини-проект}

Изучи варианты музыкальных произведений, которые можно исполнить на празднике. Составь программу праздника так, чтобы в репертуаре было по 2 музыкальных произведения в исполнении каждого инструмента.

Не забудь в программе указать название праздника, место его проведения. Придумай и запиши дату и время проведения праздника.

Варианты музыкальных произведений

для составления программы праздника

\begin{tabular}{|l|l|l|}
\hline \multicolumn{3}{|c|}{ Музыкальные произведения в исполнении } \\
\hline \multicolumn{1}{|c|}{ балалайки: } & \multicolumn{1}{|c|}{ мандолины: } & \multicolumn{1}{c|}{ курая: } \\
\hline 1. »Русская плясовая» & 1. »Родная земля» & 1. »Семь красавиц» \\
2. »Камаринская» & 2. »Апипа & 2. »Дружба» \\
3. »Ах вы, сени» & 3. Мелодия» & 3. „Старый Урал» \\
4. Тройка & 4. »Сабантуй & 4. Журавлиная песня» \\
\hline
\end{tabular}


$\ll$

Программа музыкального праздника

название праздника

Место проведения праздника

Дата

Время

В программе праздника произведения в исполнении

балалайки:

1)

2)

мандолины:

1)

2)

курая:

1)

2)

До встречи на празднике!

Комплексная работа; краеведческий музей Челябинской области (региональные особенности)

В 2013 году Челябинский краеведческий музей отметит столетие. Он был открыт 1 июля 1913 года. В июне 2006 года состоялось открытие нового здания музея, оно расположилось в историческом центре города на месте Челябинской крепости, поэтому внешние очертания музея напоминают крепостные башни и стены, фасад музея украшают стеклянные витрины.

Одной из первых в новом здании открылась уникальная экспозиция Детского музея. Она основана на идее передачи знаний о природе и истории края через сочетание экспозиции подлинных музейных предметов со сказочно-игровой подачей материала.

В мастерской Детского музея можно ознакомиться с народными ремеслами, жанрами декоративно-прикладного искусства, попробовать собственные способности к рукоделию.
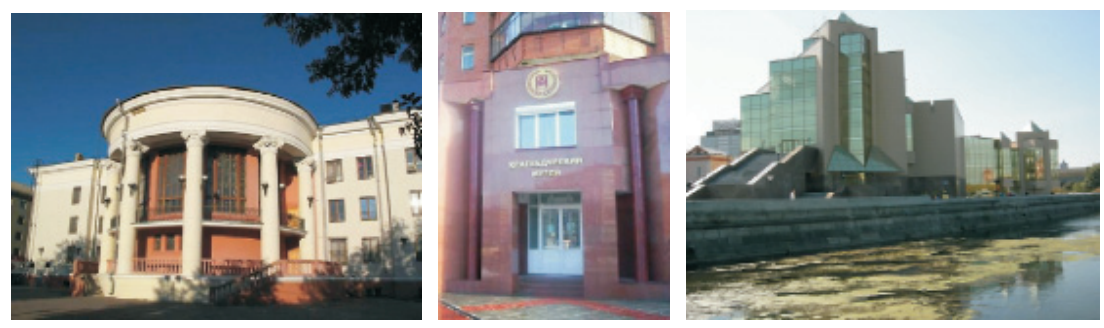


\section{Задания:}

1. На фотографии изображено здание Челябинского областного краеведческого музея. Отметь знаком + его описание.

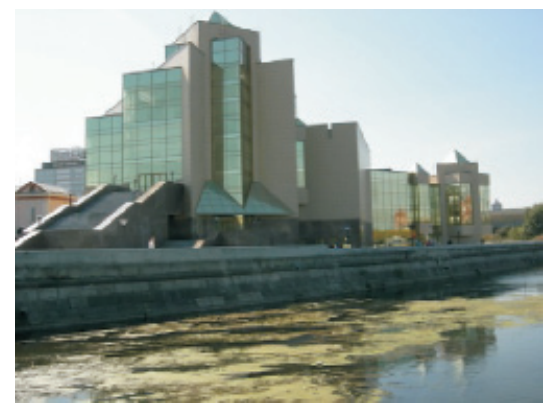

фасад музея украшает гранитная плитка.

фасад музея украшают стеклянные витрины.

$\square$ фасад музея украшают колонны белого цвета.

Посетив музей, ребята решили составить вопросы викторины. Составь и запиши сам вопросы викторины, чтобы ответами на них были даты, указанные в таблице.

\begin{tabular}{|l|c|}
\hline \multicolumn{1}{|c|}{ Задания викторины } & Даты \\
\hline В каком году музей отмечает 100-летний юбилей? & 1913 \\
\hline В каком году был открыт музей? & 2006 \\
\hline В каком году состоялось открытие нового здания музея? & 2013 \\
\hline
\end{tabular}

3. Отметь знаком + название викторины:

$\square$ краеведческие музеи Челябинской области,

$\square$ краеведческий музей Челябинской области, $\square$ экскурсионная работа в Челябинской области.

4. На сайте школы ученики пишут объявление для ребят с приглашением в мастерскую Детского музея.

Напиши три аргумента, почему ребятам стоит пойти в мастерскую Детского музея: 
5. В мастерской Детского музея многому можно научиться: тканые ремесла, художественная роспись, дымковская игрушка, художественная ковка, литье и чеканка, гжель, резьба по дереву, изделия из бересты и лозы, авторская игрушка, вологодское кружево, хохломская роспись.

Из предложенного выше списка народных ремесел Челябинской области выбери четыре названия и запиши для программы «Занятия в мастерской Детского музея». Не забудь, что записать надо, к кому ты хочешь обратиться, где состоятся занятия, придумай дату и время посещения.

\begin{tabular}{|l|}
\hline \multicolumn{1}{|c|}{ Уважаемые $\_$} \\
Приглашаем Вас, посетить занятие в \\
которое состоитя Дата _емя \\
Вы познакомитесь с народными ремеслами Южного Урала \\
\hline \\
\hline
\end{tabular}

C 27 февраля по 14 марта 2014 года в общеобразовательных учреждениях Челябинской области в рамках проекта «Разработка, апробация и внедрение инструментария и процедур оценки качества начального общего образования в соответствии с ФГОС» проходила апробация разработанных контрольных измерительных материалов для оценивания достижения обучающимися планируемых результатов освоения основных образовательных программ начального общего образования, отражающих национальные, региональные и этнокультурные особенности Челябинской области (далее КИМ с учетом НРЭО).

Апробация заключалась в проведении процедур оценивания достижения обучающимися планируемых результатов освоения основных образовательных программ начального общего образования, отражающих национальные, региональные и этнокультурные особенности Челябинской области, с применением разработанных КИМ.

Цель апробации - экспертиза и экспериментальная проверка инструментария (разработанных вариантов КИМ) для оценивания достижения обучающимися планируемых результатов освоения основных образовательных программ начального общего образования, отражающих национальные, региональные и этнокультурные особенности Челябинской области. 
Основания проведения процедуры апробации:

- Областная целевая Программа развития образования Челябинской области на 2013-2015 годы (Постановление Правительства Челябинской области от 27.09.2012 г. № 01/520-4-П);

- Приказ Министерства образования и науки Челябинской области от 27 сентября 2013 г. № 01/3482 «Об участии в апробации методических рекомендаций по учету национальных, региональных и этнокультурных особенностей при разработке и реализации основных образовательных программ начального, основного, среднего общего образования образовательных организаций, расположенных на территории Челябинской области»;

- Письмо Министерства образования и науки Челябинской области от 14.02.2014г. № 03-02/961 «О проведении апробации КИМ, составленных на материалах, отражающих национальные, региональные и этнокультурные особенности Челябинской области» в период с 27 февраля по 14 марта 2014 г.;

- необходимость создания контрольных измерительных материалов для оценивания достижения обучающимися результатов освоения основных образовательных программ начального общего образования, отражающих национальные, региональные и этнокультурные особенности Челябинской области;

- востребованность пакета диагностических материалов образовательными учреждениями Челябинской области.

Апробировались:

- 16 вариантов КИМ с учетом НРЭО (8 КИМ - регионального направления и 8 - этнокультурного);

- время выполнения заданий КИМ (не должно превышать рамок стандартного урока);

- соответствие заданий КИМ уровню требований основных образовательных программ начального общего образования ФГОС в части учёта национальных, региональных и этнокультурных особенностей Челябинской области;

- количество заданий, включенных в тест (вопрос о количестве включаемых в работу заданий решается на основании экспертного анализа и экспериментальной проверки);

- корректность формулировок заданий КИМ;

- оценочные показатели теста;

- надежность тестов (работа по определению коэффициента надежности тестовых заданий и статистической легкости и трудности продолжается в контексте анализа результатов выполнения). 
Условиями проведения апробации КИМ с учетом НРЭО следует считать:

- участие образовательных организаций в апробации методических рекомендаций по учету национальных, региональных и этнокультурных особенностей при разработке и реализации основных образовательных программ начального, основного, среднего общего образования образовательных организаций, расположенных на территории Челябинской области;

- наличие в образовательных организациях необходимого для апробации оборудования (компьютеры с подключением к сети Интернет);

- наличие необходимой информационно-методической и технической поддержки со стороны ГБУ РЦОКИО;

- наличие инструментария, обеспечивающего проведение апробации.

В качестве основных принципов, на основе которых осуществлялась апробация, были выбраны обоснованность, надежность, прозрачность и открытость - основные принципы организации процедур оценки, реализация которых сможет обеспечить доверие к самой процедуре и к её результатам. Также можно указать и следующие:

- соответствие требованиям теории педагогических измерений;

- достаточная представительность выборки экспертов и испытуемых для формулирования выводов о качестве инструментария;

- проведение апробации в схожих условиях, в которых будет использоваться разрабатываемый инструментарий.

Участниками апробации стали:

- 228 обучающихся 4 классов общеобразовательных организаций города Челябинска (были выбраны образовательные организации, которые в 2013 году участвовали в апробации «Методических рекомендаций по учету национальных, региональных и этнокультурных особенностей при разработке и реализации основных образовательных программ начального, основного, среднего общего образования образовательных организаций, расположенных на территории Челябинской области») - см. Приложение 1;

- 14 педагогов образовательных организаций, привлеченных к проведению апробации;

- 6 сотрудников ГБУ РЦОКИО (наблюдатели, консультанты).

Ниже представлено описание процедуры апробации, проведенной в 5 образовательных организациях г. Челябинска: раскрыты цели, задачи и содержание работы по каждому этапу; описаны необходимые условия проведения апробации, представлены все сопроводительные материалы (включая инструктивные) для регламентации процедур проведения 
апробации; даны результаты анализа в обобщенном виде и рекомендации по совершенствованию разработанного инструментария.

В комплексной работе оценивалась сформированность трех групा умений:

1. Общее понимание текста, ориентация в тексте;

2. Глубокое и детальное понимание содержания и формы текста;

3. Использование информации из текста для различных целей.

Ниже представлено описание этих групп умений.

Группа 1 умений включает в себя общее понимание того, о чем говорится в тексте, понимание основной идеи, поиск и выявление в тексте информации, представленной в различном виде (ориентация в тексте), а также формулирование прямых выводов и заключений на основе фактов, имеющихся в тексте.

Группа 2 умений включает в себя анализ, интерпретацию и обобщение информации, представленной в различной форме, формулирование на ее основе выводов и оценочных суждений.

Группа 3 умений включает в себя использование информации из текста для различных целей: для решения различного круга учебно-познавательных и учебно-практических задач без привлечения или с привлечением дополнительных знаний и личного опыта обучающегося.

Процедура подготовки и проведения апробации подготовленных контрольных измерительных материалов осуществлялась в несколько этапов:

1. Подготовка к проведению апробации КИМ с учетом НРЭО в образовательных организациях г.Челябинска:

- регламент проведения процедуры оценивания достижения обучающимися планируемых результатов освоения основных образовательных программ начального общего образования, отражающих национальные, региональные и этнокультурные особенности Челябинской области, включающий описание

- целей и задач проведения процедур оценивания достижения обучающимися планируемых результатов освоения основных образовательных программ начального общего образования, отражающих национальные, региональные и этнокультурные особенности;

- категорий участников процедур;

- порядка действий при проведении процедуры оценивания достижения обучающимися планируемых результатов освоения основных образовательных программ начального общего образования, отражающих национальные, региональные и этнокультурные особенности Челябинской области, с указанием ответственных участников за каждое действие, включая временные затраты на каждое действие регламента; 
- разработана электронная тестовая оболочка, в которой были размещены все КИМ, допущенные к апробации по итогам экспертизы, обеспечивающая следующие возможности:

- проведение тестирования в режиме on-line;

- авторизация и аутентификация пользователей;

- просмотр испытуемыми заданий и ввод ответов на компьютере;

- контроль за ходом проведения тестирования;

- обработка результатов тестирования;

- формирование на сервере файла с результатами тестирования;

- хранение результатов тестирования в единой базе данных;

- обеспечен доступ к системе тестирования для всех участников апробации;

- тиражированы необходимые раздаточные материалы;

- подготовлены инструкции для обучающихся и организаторов по проведению тестирования;

- подготовлены методические материалы для составления отчета по итогам апробации;

- проведено инструктивно-методическое совещание по вопросам апробации КИМ с учетом НРЭО в образовательных организациях;

- проведено пробное тестирование, дающее возможность учителям и обучающимся составить представление о структуре КИМ, количестве заданий, их форме и уровне сложности, приобрести выпускниками начальной школы опыт выполнения заданий КИМ с учетом НРЭО.

1. Проведение апробации в школах г. Челябинска, оказание консультационной помощи педагогам-апробаторам.

Выпускникам четвертых классов в течение урока (45 минут) было предложено выполнить работу, состоящую из трех частей. В первой части комплексной работы предполагалось ознакомиться с текстом и выполнить задания национального и регионального компонента, во второй части - выполнить задания на основе несплошного текста этнокультурного направления. Первая и вторая часть работы осуществлялась в тестовой оболочке на компьютере. Третья часть работы состояла из двух альтернативных вариантов творческих мини-проектов, один из которых обучающемуся необходимо было выбрать и выполнить на специально подготовленных бланках. Расчет времени и этапы проведения апробационной работы представлены в табл. 3.

2. Подготовка отчетных документов по итогам апробации.

Отчет по итогам апробации КИМ с учетом НРЭО содержит:

- общую информацию об участниках апробации;

- количественные и качественные характеристики полученных результатов апробации; 
- общее заключение о качестве контрольных измерительных материалов, рекомендации, выводы об эффективности и целесообразности применения апробируемого инструментария для конкретной целевой группы и॰предложения по доработке КИМ с целью повышения результативности их применения для оценки достижения обучающимися планируемых результатов освоения основных образовательных программ начального общего образования, отражающих национальные, региональные и этнокультурные особенности Челябинской области.

Таблица 3

Основные этапы проведения апробационной работы

\begin{tabular}{|l|l|}
\hline \multicolumn{1}{|c|}{ Этапы проведения апробационной работы } & Продолжительность \\
\hline $\begin{array}{l}\text { Подготовка учащихся к тестированию, чтение инструк- } \\
\text { ций, рекомендаций }\end{array}$ & $\begin{array}{l}\text { примерно 5 минут } \\
\text { (во время перемены) }\end{array}$ \\
\hline Проведение тестирования учащихся - первый КИМ & 15 минут (ровно) \\
\hline $\begin{array}{l}\text { Короткий перерыв, физкультминутка, инструкции по } \\
\text { второму КИМ }\end{array}$ & 2 минуты \\
\hline Проведение тестирования учащихся - второй КИМ & 15 минут (ровно) \\
\hline $\begin{array}{l}\text { Короткий перерыв, физкультминутка, инструкции по } \\
\text { творческому заданию }\end{array}$ & 2 минуты \\
\hline Выполнение творческого задания & 11 минут (ровно) \\
\hline Сбор печатных материалов и завершение тестирования & $\begin{array}{l}5 \text { минут (со звонком } \\
\text { на перемену) }\end{array}$ \\
\hline
\end{tabular}

3. Анализ полученных результатов. Подготовка рекомендаций по совершенствованию разработанных материалов.

Результаты апробации КИМ с учетом НРЭО представлены образовательными организациями в соответствии с »Методическими рекомендациями для составления отчета по итогам апробации контрольных измерительных материалов». По каждому классу, учебной группе, принимавшим участие в апробации КИМ, были подготовлены:

1. Краткие итоги апробации контрольных измерительных материалов регионального и этнокультурного направлений.

2. Анализ результатов апробации контрольных измерительных материалов регионального и этнокультурного направлений.

3. Общие заключения о качестве контрольных измерительных материалов и рекомендации по их доработке.

Педагогам, участвовавшим в апробации, необходимо было оценить по ряду позиций в баллах апробированные КИМ каждого из направлений. Полученные результаты по каждому КИМ представлены в табл. 4. 
Глава 1

\begin{tabular}{|c|c|c|c|c|c|}
\hline \multirow{8}{*}{$\begin{array}{l}\nabla \\
\sigma \\
\exists \\
\Xi \\
\sigma \\
0 \\
\sigma \\
\sigma\end{array}$} & 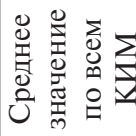 & & $\hat{\sigma}$ & $\begin{array}{l}0 \\
\dot{\sigma}\end{array}$ & ने \\
\hline & I & i & F & F & in \\
\hline & $\frac{\pi}{2}$ & $\approx$ & $n$ & $\stackrel{\gamma}{*}$ & in \\
\hline & $\stackrel{0}{2}$ & $\stackrel{\sim}{\sim}$ & $\stackrel{m}{*}$ & $\stackrel{m}{*}$ & $n$ \\
\hline & & $=\ddot{2}$ & in & $\hat{\theta}$ & in \\
\hline & 司高 & $\vec{\sim}$ & $n$ & $\tilde{\sigma}$ & $n$ \\
\hline & $\frac{\nabla}{\infty}$ & 는 & $\hat{\sigma}$ & $\stackrel{?}{+}$ & in \\
\hline & $\begin{array}{lll}5 & 0 \\
0 & 0 & 1\end{array}$ & $\infty$ & in & $\hat{\sigma}$ & in \\
\hline \multirow{10}{*}{ 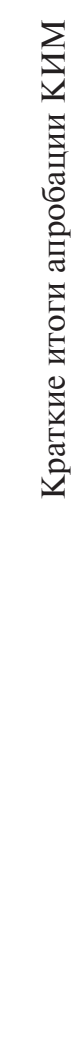 } & 壳 & 50 & in & in & in \\
\hline & 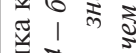 & \pm & in & in & $n$ \\
\hline & $\begin{array}{ll}0 & 0 \\
0 & 0\end{array}$ & 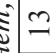 & in & in & in \\
\hline & 践 & 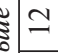 & in & $n$ & $n$ \\
\hline & 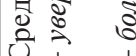 & 5 & in & $\tilde{\sigma}$ & $n$ \\
\hline & in & $a$ & $n$ & $\nabla$ & $n$ \\
\hline & ¿ & $\infty$ & $n$ & $\stackrel{n}{f}$ & $\stackrel{n}{*}$ \\
\hline & $\$$ & 6 & $n$ & $\stackrel{n}{*}$ & $n$ \\
\hline & 0 & $\sim$ & in & $\stackrel{n}{*}$ & in \\
\hline & 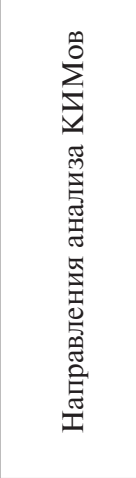 & - & 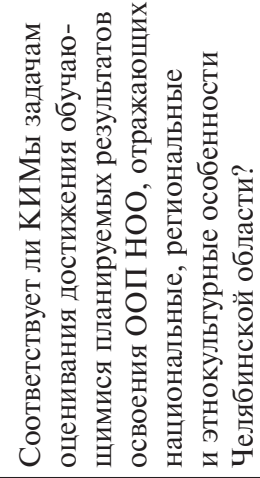 & 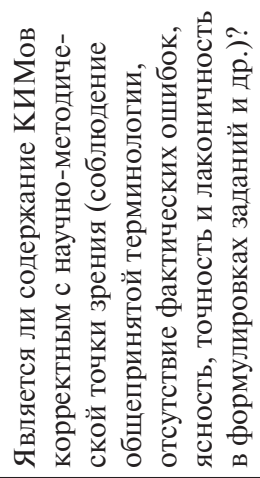 & 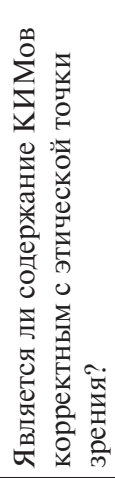 \\
\hline
\end{tabular}




\begin{tabular}{|c|c|c|c|c|c|c|c|}
\hline 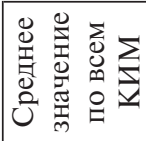 & & $\stackrel{\infty}{\forall}$ & $\cong$ & $\stackrel{n}{f}$ & शे & भे & $n$ \\
\hline \multirow{3}{*}{ 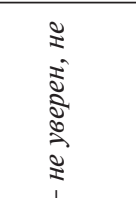 } & 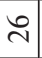 & in & $\stackrel{m}{i}$ & $\stackrel{m}{q}$ & in & $n$ & $n$ \\
\hline & $\approx$ & $n$ & $\stackrel{2}{=}$ & $\dot{\gamma}$ & $n$ & in & $n$ \\
\hline & $\stackrel{\sim}{\sim}$ & in & $m$ & $\hat{r}$ & in & in & in \\
\hline \multirow{4}{*}{ 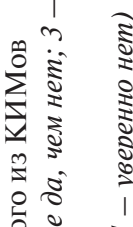 } & $\approx$ & in & $\cong$ & $\tilde{q}$ & in & in & in \\
\hline & $\vec{\sim}$ & in & $\cong$ & $\tilde{r}$ & in & in & in \\
\hline & ণ & in & $\stackrel{m}{=}$ & $\nabla$ & in & in & $n$ \\
\hline & $\infty$ & in & $\approx$ & $\tilde{r}$ & in & in & in \\
\hline 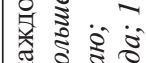 & $\underline{-}$ & $\begin{array}{l}n \\
\forall\end{array}$ & $\because$ & $\begin{array}{l}n \\
\forall\end{array}$ & $n$ & in & in \\
\hline 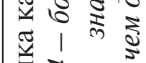 & \pm & $\stackrel{n}{*}$ & 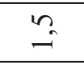 & $\begin{array}{l}n \\
\dot{\gamma}\end{array}$ & $n$ & in & in \\
\hline $\begin{array}{ll}\frac{1}{0} & + \\
0 & 0 \\
0 & 0\end{array}$ & $\cong$ & 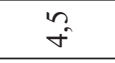 & $\because$ & $n$ & $n$ & in & in \\
\hline 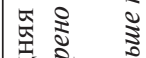 & $\simeq$ & $\stackrel{n}{*}$ & $\sim$ & $\stackrel{n}{*}$ & $n$ & $\stackrel{n}{*}$ & in \\
\hline 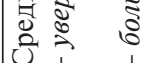 & 으 & $n$ & $\cong$ & $\stackrel{m}{r}$ & $n$ & in & in \\
\hline \multirow{4}{*}{ 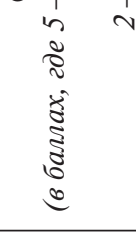 } & $a$ & in & $\sim$ & $\nabla$ & $n$ & in & in \\
\hline & $\infty$ & $n$ & $\sim$ & $\nabla$ & $n$ & 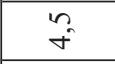 & $n$ \\
\hline & 6 & $n$ & $\because$ & $\begin{array}{l}n \\
\forall\end{array}$ & in & in & in \\
\hline & $\sim$ & 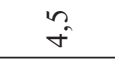 & $\because$ & $n$ & $n$ & $n$ & in \\
\hline 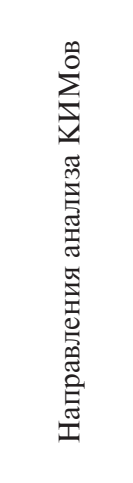 & -1 & 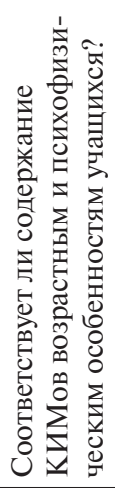 & 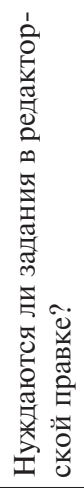 & 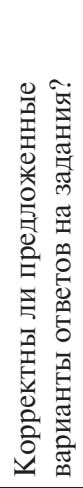 & 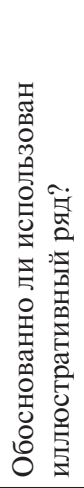 & 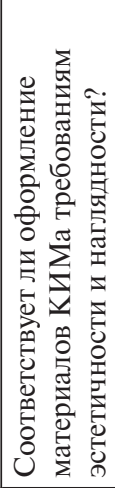 & 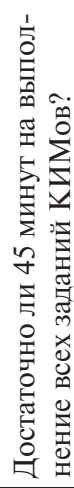 \\
\hline
\end{tabular}


Среднее значение практически по всем позициям, представленным для анализа, довольно высоко - от 4,6 балла до 5 баллов, что свидетельствуют о том, что все апробируемые КИМ соответствуют задачам оценивания достижения обучающимися планируемых результатов ООП НОО, отражающих национальные, региональные и этнокультурные особенности Челябинской области. Содержание всех КИМ является корректным с научно-методической и этической точки зрения, соответствует возрастным и психофизическим особенностям учащихся.

Большая часть заданий КИМ не нуждается в редакторской правке, по мнению апробаторов, необходима корректировка заданий только КИМ № 24. Оформление материалов КИМ и представленный в них иллюстративный ряд соответствуют требованиям эстетичности и наглядности. В ходе апробации в КИМ не были обнаружены опечатки, некорректно сформулированные фразы, вопросы, задания.

Фиксируя краткие итоги апробации КИМ, апробаторы не внесли никаких предложений по совершенствованию контрольных измерительных материалов.

Каждая комплексная работа по региональному и этнокультурному направлению была разработана с целью выявления у обучающихся 4-х классов одного из основных метапредметных результатов обучения - сформированности умений читать и понимать различные тексты; работать с информацией, представленной в различной форме; использовать полученную информацию для решения различных учебно-познавательных и учебнопрактических задач. Учащимся предлагалось прочитать предложенный текст и выполнить задания, связанные непосредственно с информацией текста, а также с разными учебными предметами и личным опытом школьника. При ответе на одни задания необходимо было выбрать из предложенных вариантов один правильный ответ, в других требовалось дать свободный самостоятельно сконструированный краткий или развернутый ответ.

В работе оценивалась сформированность трех групп умений.

Задание № 1 первой (региональной) части комплексной работы и второй (этнокультурной) было направлено на выявление сформированности первой группы умений: понимать информацию, представленную разными способами: словесно, в виде таблицы, схемы, диаграммы, рисунка.

Полученные данные свидетельствуют о том, что выполнение задания не представляло сложности для обучающихся, так как абсолютное большинство справилось с заданием данного типа $(96 \%$ - региональное направление и $94 \%$ - этнокультурное).

В теории педагогических измерений сложность задания - характеристика задания, отражающая статистический уровень решаемости в дан- 
ной выборке стандартизации. Показателем сложности задания является доля выборки испытуемых, которые решили или не решили данную задачу, справились или не справились с заданием. Например, если всего $20 \%$ испытуемых выполнили задание, его можно считать сложным для данной выборки, если $80 \%$ - легким.

Задание, направленное на выявление сформированности умения понимать информацию, представленную разными способами, является легким для данной выборки обучающихся.

Задание № 2 КИМ было направлено на выявление сформированности у обучающихся второй группы умений: анализировать, сопоставлять, интерпретировать и обобщать информацию, содержащуюся в разных частях текста, представленную в различной форме.

Справились со 2 заданием региональной части КИМ (получили 2 или 3 балла) $-84 \%$ обучающихся. Справились со 2 заданием этнокультурной части КИМ (получили 2 или 3 балла) $-75 \%$ обучающихся. Не справились с заданием (получили 1 или 0 баллов) - 16 и $25 \%$ обучающихся соответственно. Полученные результаты позволяют сделать вывод, что три четверти обучающихся овладели умением анализировать, сопоставлять, интерпретировать и обобщать информацию, содержащуюся в разных частях текста, представленную в различной форме.

Наиболее сложным для школьников оказалось задание № 2 КИМ № $6,10,12,16,20$, с ним не справились (получили 0 баллов) до $38 \%$ обучающихся. Основными проблемами, связанными с выполнением задания и зафиксированными преподавателями, стали неумение обучающихся четко излагать свои мысли, преобразовывать информацию текста в соответствии с заданием, невнимательность, проявленная при знакомстве с заданием, и как следствие, подмена более сложного задания простым.

Часть преподавателей обозначила второе задание как трудное, сложное для обучающихся. Но по данным отчетов по итогам апробации КИМ с учетом НРЭО со 2 заданием всех КИМ справились более $50 \%$ обучающихся, следовательно, задание не является трудным для обучающихся. Однако разработчикам КИМ необходимо пересмотреть и откорректировать формулировки второго задания (особенно в КИМ № 6, 10, 12, 16, $20)$, а учителям большее внимание следует уделить формированию у обучающихся умений сопоставлять, обобщать информацию, содержащуюся в разных частях текста, и преобразовывать ее, формулировать прямые выводы и заключения на основе фактов, имеющихся в тексте.

Задание № 3 КИМ направлено на выявление сформированности умения в процессе работы с одним или несколькими источниками выявлять достоверную (противоречивую) информацию. 
Выполнение третьего задания не вызвало затруднений у обучающихся, абсолютное большинство (80\% - региональное направление и $84 \%$ этнокультурное) справилось с заданием данного типа.

Из всех вариантов третьих заданий КИМ, более сложным казалось задание КИМ № 8 (региональное направление) и КИМ № 20 (этнокультурное направление).

Основная проблема, связанная с выполнением 3 задания, которая была указана преподавателями в отчетах, - у обучающихся не сформировано умение работать с текстом. Следовательно, преподавателям, реализующим образовательную программу начального общего образования, работающим с учащимися 4-х классов, необходимо направить усилия на формирование у обучающихся умений работы с текстом, особенно на формирование умения в процессе работы с одним или несколькими источниками выявлять достоверную (противоречивую) информацию.

Задание № 4 КИМ было направлено на выявление сформированности у обучающихся умения 3 группы: на основе имеющихся знаний, жизненного опыта находить пути восполнения недостающей информации.

Справились с 4 заданием региональной части КИМ (получили 2 или 3 балла) $-72 \%$ обучающихся. Такой же результат получен и по итогам выполнения 4 задания этнокультурной части КИМ: получили 2 или 3 балла $72 \%$ обучающихся. Не справились с заданием (получили 1 или 0 баллов) -28 и $28 \%$ обучающихся соответственно.

Наиболее сложным для обучающихся оказалось задание 4 КИМ № $8,10,12,14,18$. Типичные проблемы, выявленные при выполнении 4 задания этих КИМ:

- обучающиеся не умеют формулировать и аргументировать собственные мысли,

- часто дают краткие однообразные ответы, не соотнесенные с текстом.

Следовательно, преподавателям на учебных занятиях необходимо организовать работу, направленную на овладение обучающимися логическими действиями анализа, сравнения, синтеза, обобщения, установления аналогий и причинно-следственных связей, построения рассуждения, продолжить работу по формированию у обучающихся 4-х классов умений на основе имеющихся знаний, жизненного опыта находить пути восполнения недостающей информации, представлять и аргументировать собственное мнение, собственную позицию.

Важной особенностью комплексной работы является включение задания № 5, представляющего собой творческий мини-проект, проверяющий сформированность третьей группы умений, напрямую не связанных с текстом, но для выполнения которого требуется информация, полученная 
из прочитанного текста. Именно это задание оценивает сформированность умений связывать полученную информацию из текста с предложенными проблемами и использовать ее для их решения.

Обучающимся было предложено выбрать для выполнения один проект из двух предложенных (мини-проекты этнокультурного и регионального направления) и выполнить его на специально подготовленном бланке.

Каждый проект предполагал оценку сформированности третьей группы умений, а именно использование информации из текста для различных целей: для решения различного круга учебно-познавательных и учебно-практических задач без привлечения или с привлечением дополнительных знаний и личного опыта обучающихся. Экспертной оценке подлежало также соответствие подготовленного продукта (проекта) требованиям задания, умение отбирать и преобразовывать информацию, формулировать собственное мнение и позицию.

Выполняли индивидуальные мини-проекты все 228 учащихся четвертых классов, из них $51 \%$ обучающихся выбрал творческий проект регионального направления и $49 \%$ - этнокультурного, следовательно, все предложенные для реализации мини-проекты регионального и этнокультурного направления в равной степени были интересны обучающимся.

Распределение баллов по итогам выполнения обучающимся минипроектов каждого из направлений представлены в табл. 5.

Та блица 5

Общие результаты выполнения творческих мини-проектов

\begin{tabular}{|c|c|c|}
\hline \multirow{2}{*}{ Кол-во баллов } & \multicolumn{2}{|c|}{$\begin{array}{r}\text { Кол-во обучающихся, получивших данный баллы } \\
\text { по итогам выполнение проекта (в \%) }\end{array}$} \\
\cline { 2 - 3 } & региональное направление & этнокультурное направление \\
\hline 6 баллов & 42 & 37 \\
\hline 4 балла & 36 & 33 \\
\hline 2 балла & 14 & 20 \\
\hline 0 баллов & 8 & 10 \\
\hline
\end{tabular}

Данные, представленные в табл. 5, показывают, что каждый третий обучающийся получил за выполнение мини-проекта максимальный балл, что свидетельствует о сформированности у них умения связывать полученную информацию из текста с предложенными проблемами и использовать ее для решения проблем. 
Не справились с заданием (получили 0 баллов) только $10 \%$ обучающихся. Обозначим проблемы, выявленные при выполнении работы:

- обучающиеся очень невнимательны при ознакомлении с инструкцией к заданию,

- не умеют выполнять работу четко в соответствии с заданием,

- не могут правильно указать аппарат ориентировки.

Для решения выше обозначенных проблем учителям необходимо чаще использовать на учебных занятиях проектный метод, способствующий развитию познавательных, творческих навыков обучающихся, приобретению детьми опыта исследовательско-творческой деятельности, умений самостоятельно конструировать свои знания и ориентироваться в информационном пространстве.

Таким образом, общий анализ результатов выполнения отдельных заданий показал, что лучше всего четвероклассники справились с заданиями первой группы умений на общее понимание текста и ориентацию в тексте. Большую сложность представляет для обучающихся выполнение заданий, оценивающих глубокое и детальное понимание содержания и формы текста, а также заданий по использование информации из текста для различных целей.

Полученные данные говорят о том, что у выпускников начальной школы лучше сформированы умения находить информацию, представленную в тексте в явном виде, понимать информацию, представленную разными способами (словесно, в виде таблицы, схемы, диаграммы, рисунка), в процессе работы с одним или несколькими источниками выявлять достоверную (противоречивую) информацию.

Результаты снижаются, если:

- нужно сопоставить и обобщить информацию, содержащуюся в разных частях текста (задание 2);

- или нужно на основе имеющихся знаний, жизненного опыта находить пути восполнения недостающей информации (задание 4);

- или необходимо формулировать собственное мнение и позицию (задание 5).

После выполнения всех заданий комплексной работы учитель может подсчитать для каждого ученика интегральную оценку выполнения работы, как процент от максимального балла за выполнение отдельных блоков и всей работы в целом. Эти данные помогут ему сформировать представление о способности класса решать поставленные учебные задачи, используя знания, полученные в начальной школе. 
Статистический анализ результатов выполнения работы позволил сделать следующие выводы:

1. Предложенные варианты комплексной работы по характеру распределения результатов обучающихся соответствуют требуемому уровню трудности измерительных материалов. Полученные результаты также свидетельствуют и о необходимости повысить уровень сложности заданий № 1, № 3 комплексной работы (они оказались легкими для обучающихся).

2. Распределение результатов обучающихся по итогам выполнения комплексной работы (обучающимися продемонстрированы примерно одинаковые результаты сформированности разных групп умений) свидетельствует о том, что большинство вариантов КИМ равнозначны по сложности. При дальнейшей доработке заданий и вариантов КИМ необходимо провести выравнивание всех вариантов по уровню их сложности.

3. Все обучающиеся успели выполнить задания комплексной работы в течение урока, недостаток времени на выполнение заданий КИМ в качестве проблемы апробаторами не был зафиксирован. Следовательно, время выполнения заданий КИМ укладывается в рамки стандартного урока (45 мин).

4. Целесообразно рассмотреть возможность разработки дополнительных заданий для учащихся (заданий повышенного уровня сложности).

Общие заключения о качестве контрольных измерительных материалов и рекомендации по их доработке, представленные организаторами проведения апробации, продемонстрировали следующее:

1. Задания КИМ соответствуют нормативным требованиям Федерального закона «Об образовании в Российской Федерации», приказу Министерства образования и науки Челябинской области от 06 октября 2009 года № 373 «Об утверждении и введении в действие федерального государственного образовательного стандарта начального общего образования» и направлены на определение уровня достижения метапредметных результатов освоения ООП НОО.

2. КИМ составлены на материалах, отражающих национальные, региональные, этнокультурные особенности Челябинской области, соответствуют основному назначению и возрастным особенностям обучающихся. Все задания КИМ представлены в форме учебно-познавательных и учебно-практических задач.

3. Основными достоинствами апробированных КИМ являются:

- сочетание текстовой и нетекстовой информации;

- предоставление для обучающихся возможности переключения внимания с текстового материала на иллюстративный, что особенно 
важно для детей с различным уровнем сформированности внимания, зрительной памяти, абстрактного мышления;

- рациональная конструкция заданий;

- интересный содержательный аспект КИМ.

Особо отмечены актуальность и значимость КИМ как одного из элементов нравственного, эстетического и гражданского воспитания, привлечения школьников к познанию родного края.

Представленные в общих заключениях предложения по доработке КИМов касаются необходимости корректировки ряда формулировок (в основном корректировки 5-х заданий КИМ), уменьшения времени на тестовую часть КИМ и увеличения времени на 5 задание (должно выполняться не менее 10 мин.). Также апробаторы рекомендовали включить в КИМ ряд дополнительных заданий для обучающихся, закончивших работу раньше других.

Все КИМ (100\%) рекомендованы к использованию для оценки достижения обучающимися планируемых результатов освоения ООП НОО, отражающих национальные, региональные и этнокультурные особенности Челябинской области.

Основным источником информации для установления отношения обучающихся к выполнению комплексной работы с использованием апробируемых КИМ является анализ материалов анкетирования, проведенного с каждой группой обучающихся.

Цель анкетирования - узнать мнение обучающихся о сложности заданий, новизне содержания КИМов, наличии усталости после завершения работы, а также о проявлении интереса к такому виду деятельности.

Данные, полученные нами по итогам анкетирования, представлены в приложении 5.

В целом, результаты анкетирования позволяют заключить, что обучающиеся проявили высокий интерес к выполнению заданий КИМ (интересно было выполнять задания КИМ регионального направления $88 \%$ обучающихся, задания КИМ этнокультурного направления - 84\% обучающимся).

Оказались сложными для выполнения задания КИМ этнокультурного направления для 30 обучающихся и для 33 обучающихся - задания КИМ регионального направления, что составляет 13 и $15 \%$ соответственно. Следует отметить, что почувствовали усталость по завершении работы только 16 обучающихся (7\%), «не очень устали» - 54 обучающихся (24\%), не почувствовали усталости после завершения работы больше половины обучающихся $-69 \%$.

На новизну содержания КИМов указали $83 \%$ обучающихся, $90 \%$ обучающихся продемонстрировали желание принять участие в подобной работе еще раз. 
Таким образом, анализ материалов анкет учащихся 4-х классов, участвовавших в апробации КИМ с учетом НРЭО, показал, что такой вид деятельности вызвал у обучающихся желание принять участие в подобной форме контроля еще раз, а также познавательный интерес к национальным, региональным и этнокультурным особенностям Челябинской области.

Таким образом, анализ результатов апробации КИМ позволяет сделать вывод о достаточно высоком качестве разработанных контрольных измерительных материалов, позволяющих оценить достижение обучающимися планируемых результатов освоения основных образовательных программ начального общего образования, отражающих национальные, региональные и этнокультурные особенности Челябинской области.

Данные отчетов по итогам апробации КИМ с учетом НРЭО а также общие заключения о качестве КИМ показали, что

- в целом модель инструментария (КИМ с учетом НРЭО) была одобрена учителями-апробаторами и экспертами;

- апробированные КИМ составлены на материалах, отражающих национальные, региональные, этнокультурные особенности Челябинской области, соответствуют основному назначению и возрастным особенностям обучающихся;

- задания КИМов соответствуют нормативным требованиям Федерального закона «Об образовании в Российской Федерации», приказу Министерства образования и науки Челябинской области от 06.10.2009 г. № 373 «Об утверждении и введении в действие Федерального государственного образовательного стандарта начального общего образования» и направлены на определение метапредметных результатов освоения основных образовательных программ начального общего образования, а также соответствуют требованиям, предъявляемым к измерительным материалам: обоснованности, надежности, объективности, сопоставимости результатов выпускников четвертых классов;

- время выполнения заданий КИМов укладывается в рамки стандартного урока (45 минут);

- большинство апробированных вариантов КИМ равнозначно по сложности;

- все апробированные КИМ рекомендованы к использованию для оценки достижения обучающимися планируемых результатов освоения основных образовательных программ начального общего образования, отражающих национальные, региональные и этнокультурные особенности Челябинской области;

- используемая при проведении апробации технология компьютерного тестирования учащихся, позволила обеспечить: 
- возможность независимого оценивания достижения обучающимися планируемых результатов освоения основных образовательных программ начального общего образования, отражающих национальные, региональные и этнокультурные особенности Челябинской области;

- возможность хранения результатов аттестационного тестирования обучающихся образовательных организаций в единой базе данных;

- возможность импорта данных, полученных при проведении тестирования, в единую базу данных.

- разработанные КИМ позволяют дифференцировать подготовку обучающихся в данной области метапредметных результатов, дают возможность учителям на основе полученных результатов организовать индивидуальную работу с учащимися как в 4-м классе, так и при переходе в основную школу - в 5-м классе.

Таким образом, разработанная нами модель КИМов была проэкспертирована специалистами ГБУ «Региональный центр оценки качества и информатизации образования» (г. Челябинск) в январе 2014 года и утверждена для использования в качестве конструкции для составления серии КИМов по определенной тематике с целью создания банка контрольно-измерительных материалов для оценивания достижения обучающимися планируемых результатов освоения основной образовательной программы начального общего образования, отражающих региональные и этнокультурные особенности Челябинской области.

На основе проведенного анализа можно сформулировать следующие рекомендации по доработке и апробации КИМ для оценивания достижения обучающимися планируемых результатов освоения основных образовательных программ начального общего образования, отражающих национальные, региональные и этнокультурные особенности Челябинской области:

1. Доработать тексты заданий КИМ с учетом замечаний, высказанных учителями в ходе проведения апробации и представленных в отчетах педагогов-апробаторов.

2. При дальнейшей доработке заданий и вариантов КИМ необходимо провести выравнивание всех вариантов по уровню их сложности.

3. Рассмотреть возможность разработки дополнительных заданий для учащихся (заданий повышенного уровня сложности).

4. При анализе и интерпретации результатов выполнения комплексной работы полезно учитывать следующие критерии сформированности умений: минимальный критерий сформированности умения (успешность выполнения равна $50 \%$ ) и оптимальный критерий (успешность выполнения равна $65 \%$ ). 
5. Качественную оценку освоения ключевых умений проводить по шкале с тремя позициями:

1) умение освоено;

2) умение формируется;

3) умение не освоено.

Умение считается освоенным, если обучающийся верно выполнил все задания, проверяющие данное умение; неосвоенным, если обучающийся не смог верно выполнить ни одно задание, проверяющее данное умение. Заключение о том, что умение обучающегося находится в стадии формирования, делается, если он верно выполнил часть заданий на данное умение.

6. Для установления прогностичности и валидности КИМ необходимо продолжить апробацию, увеличив и расширив базу исследования, включив в нее образовательные учреждения городских округов и муниципальных районов Челябинской области.

\section{Библиографический список:}

1. Как проектировать универсальные учебные действия в начальной школе. От действия к мысли : пособие для учителя / А.Г. Асмолов [и др.]; под ред. А.Г. Асмолова - 2-е изд. - М. : Просвещение, 2010. - 152 с.

2. Методические рекомендации по учету национальных, региональных и этнокультурных особенностей при разработке общеобразовательными учреждениями основных образовательных программ начального, основного, среднего (полного) общего образования / В. Н. Кеспиков, М. И. Солодкова, Е. А. Тюрина и др..; Мин-во образования и науки Челяб. обл.; Челяб. ин-т переподгот. и повышения квалификации работников образования. - Челябинск: ЧИППКРО, 2013. - 164 с.

3. Планируемые результаты начального общего образования / Л.Л. Алексеева [и др.]; под ред. Г.С. Ковалевой, О.Б. Логиновой. - 2-е изд. - М.: Просвещение, 2010. - 120с. - (Стандарты второго поколения).

4. Разработка тестов и анкет для национальной оценки учебных достижений / Пру Андерсен, Джордж Морган; пер. с англ. В.Н. Симкина; научн. ред. В.И.Звонников. - М.: Логос, 2011. - 196 с.: ил. - (Национальная оценка учебных достижений). 


\section{ЭКОЛОГИЧЕСКИЕ ПРОЕКТЫ В ОБРАЗОВАНИИ МЛАДШЕГО ШКОЛЬНИКА}

Е.В. Осолодкова

Важной задачей современного общества, в сложившейся ситуации, когда взаимодействие человека и природы превратилось в одну из актуальных и тревожных проблем, является экологическое воспитание подрастающего поколения.

В проекте Федерального закона «Об экологической культуре» подчеркивается, что в младшем школьном возрасте закладываются этические принципы отношения к природе. Целью экологического образования младших школьников является воспитание экологической культуры, то есть выработка навыков гуманно-действенного и эмоционально-чувственного взаимодействия с природными объектами; понимание детьми элементарных взаимосвязей, существующих в природе, и особенностей взаимодействия человека с ней. Формирование начальных основ экологической культуры у детей младшего школьного возраста требует включения определенного содержания, методов и форм работы, а так же создание условий, необходимых для постоянного общения детей с природными объектами. В решении данной проблемы большую роль играет проектная деятельность, где возможно использование разнообразных видов познавательной, воспитательной и научной деятельности.

В новых ФГОС особое внимание уделяется методу проектов как решающему фактору в формировании у ребёнка умения учиться. У детей младшего школьного возраста имеется определенный интерес к окружающей их природе, но он еще не прочен и ограничен. В процессе проектной деятельности познавательный интерес детей начинает выступать движушей силой в поисках ответов на многие вопросы, появляется желание больше узнать, развивать активность и умственную деятельность. Острота современных экологических проблем выдвинула перед педагогами задачу воспитания молодого поколения в духе бережного, ответственного отношения к ней, способного решать вопросы рационального природопользования, защиты и возобновления природных богатств.

Необходимость проведения проектной деятельности обуславливается не только тем, что дети хотят больше узнать о природе, но и тем, что позволяет углублять и применять на практике знания, предусмотренные программой, развивать интерес к предмету. При вовлечении младших 
школьников в работу над проектами появляется больше возможностей для поддержания развития и закрепления познавательных интересов детей, удовлетворения любопытности.

Также во время работы над проектом дети шире и глубже изучают природу, ее компоненты и их отличительные признаки, убеждаются в связи организмов с окружающей средой, наглядно видят влияние человека на природу. Это подводит их к пониманию взаимосвязи в природе, ее материальности, формируется понятие о научной карте мира.

Работа над проектом даёт широкое поле для воспитания ответственности за порученное дело, проявление инициативы, взаимопомощи. Любовь к природе, бережное отношение к ее богатствам не приходят сразу. Это результат целенаправленной деятельности и кропотливой работы не только при изучении природы, но и вовлечение детей в посильное участие охраны природы (размножение и выращивание комнатных растений в школе и дома, работа на пришкольном участке, заготовка корма для птиц и т. д.).

Отношение человека к природе и его мировоззрение зависит от степени эффективности естественнонаучного просвещения населения, где важным и необходимым звеном является экологическое образование младших школьников.

В младшем школьном возрасте дети способны устанавливать разнообразные связи между объектами и явлениями природы, усваивать системные знания о взаимосвязи человека и природы. Чем глубже семилетний ребенок познает окружающий мир, тем многообразнее его отношение к действительности: к окружающей природе, людям, к самому себе. Это отношение ярко проявляется в чувствах: интеллектуальных (любознательность, пытливость, радость от узнавания нового) и эстетических. Развитие воли в младшем школьном возрасте определяется мотивами поведения. В шесть лет ребенок способен подчинить свое поведение наиболее значимому мотиву. Важнейшим новообразованием в этом возрасте является преобладание мотива «я должен» над мотивом «я хочу», что может стать основой для формирования у детей экологически безопасного поведения в окружающей его среде.

На протяжении десятилетий метод проектов не был востребован, его «второе рождение» в начале 90 -х годов XX века произошло достаточно стихийно, преимущественно в учебном процессе и еще не получило должного теоретического обоснования, методической разработки. Вместе с тем, очевидно, что он обладает особым воспитательным потенциалом и его использование может способствовать повышению результативности воспитания у детей экологической культуры. 
Метод проектов, разработанный зарубежными педагогами, а затем адаптированный к российским условиям отечественными учеными начала XX века, долгое время был предан забвению. Его возрождение началось с 1990-х годов. Однако применение метода проектов в современных условиях требует специального историко-педагогического анализа, который позволил бы выявить подходы основоположников этого метода к определению его сущности, специфики, причины возникших при его применении проблем. Особого внимания заслуживают подходы к применению метода проектов в области воспитания, поскольку до сих пор воспитательному потенциалу метода проектов уделялось крайне мало внимания, мало востребованными остаются подходы отечественных ученых 1920-х годов, применивших метод проектов в области воспитания. Будучи заявленным зарубежными специалистами как метод обучения, образования, метод проектов до сегодняшнего дня остается в той же интерпретации и в российских изданиях, что существенно ограничивает его использование и не вполне соответствует представлениям основоположников метода проектов о его педагогическом потенциале. Истоки метода проектов находятся в философско-педагогических концепциях и образовательной практике сельскохозяйственных школ США конца XIX века. Его называли также «методом проблем», и связывался он с идеями гуманистического направления в философии и образовании американского философа и педагога John Dewey, а также его ученика Garin Kilpatrick. Практическое применение теории John Dewey осуществлял в экспериментальной «школе-лаборатории» при Чикагском университете (1896-1904 гг).

Несмотря на то, что метод проектов возник как метод обучения и разрабатывался его создателями как образовательная технология, в нем изначально предполагался особый развивающий личность потенциал. Это направленность обучения на «связь с жизнью», на практическое применение полученных знаний, на социализацию ученика, как показывает анализ работ John Dewey и Garin Kilpatrick [3]. Ключевой идеей философско-педагогической концепции John Dewey являлось утверждение о том, что формирование мышления школьника, выступающее главным результатом обучения, должно основываться на его личном опыте. John Dewey разработал теорию формирования личности, приспособленной к жизни и практической деятельности в условиях системы свободного предпринимательства.

Проектируя трудовую школу, John Dewey видел ее фундамент в организации творческого труда детей, который и будет сосредоточением всей учебно-воспитательной работы. Он предлагал строить обучение 
на активной основе, через целесообразную деятельность ученика, сообразуясь с его личным интересом именно в определенном знании. Отсюда чрезвычайно важно было показать детям их личную заинтересованность в приобретаемых знаниях, которые могут и должны пригодиться им в жизни. Поэтому необходимо обращение к проблеме, взятой из реальной жизни, знакомая и значимая для ребенка, для решения которой ему необходимо применить полученные знания, умения и навыки, а также искать новые знания, которые позволят достичь поставленной цели. Учитель может подсказать источники информации, а может просто направить мысль учеников в нужном направлении для самостоятельного поиска. В результате ученики должны самостоятельно или в совместных усилиях решить проблему, применив необходимые знания подчас из разных областей, получить реальный и ощутимый результат. Следовательно, работа над проблемой задает контуры проектной деятельности и позволяет формировать личный опыт ребенка по взаимодействию с социокультурным пространством ближайшего окружения

Теоретические положения, на которых базируется метод проектов, восходят и к ряду других образовательных идей конца XIX начала $\mathrm{XX}$ века. В аналитических исследованиях этот период традиционно связывают с пересмотром теоретических основ образования. Чрезвычайно любопытной представляется причина этого пересмотра - неадекватность уровня развития педагогической мысли и реально существующих образовательных систем. Более века назад педагоги осознали, что жесткое регламентирование интеллектуальной деятельности, абсолютная заданность развития грозят стать тормозящим фактором, ограничивающим инициативу и творческие возможности обучающегося. Такой поворот педагогической мысли привел к зарождению концепций «свободного воспитания», поднял волну создания «свободных», «открытых» школ, детских общин, экспериментальной педагогики. Авторов «новой школы», независимо друг от друга проводивших свои исследования во Франции (Alfred Bine), Германии (Meumann), Швейцарии ((Edouard Claparède), США (Edward Lee Thorndike) и др., объединяла убежденность в необходимости развивать творческие, природные задатки учащегося, предоставляя ему возможность на собственном опыте активно познавать мир.

Этому теоретическому положению вполне соответствовало философско-педагогическое обоснование потенциала метода проектов, заимствованное его основоположниками из концепции John Dewey: стимулирование интереса учащихся к определенным проблемам, предполагающим владение определенной суммой знаний, решению их через проектную деятельность; формирование умения практически применять 
полученные знания; развитие рефлекторного (или критического) мышления. Суть рефлекторного мышления, по мнению ученого, вечный поиск фактов, их анализ, размышления над их достоверностью, логическое выстраивание фактов для познания нового, для нахождения выхода из сомнения, формирование уверенности, основанной на аргументированном рассуждении. «Потребность в разрешении сомнения является постоянным и руководящим фактором во всем процессе рефлексии. Где нет вопроса или проблемы для разрешения, или где нет затруднения, которое нужно преодолеть, поток мыслей идет наобум... Проблема устанавливает цель мысли, а цель контролирует процесс мышления»[3].

Трансформации проектной философии John Dewey в практическую, методическую плоскость способствовали работы Garin Kilpatrick, опубликовавшего в 1918 г. свою книгу «Метод проектов», которая, по утверждению ряда исследователей, стала первой работой, в которой этот метод стал самостоятельным предметом рассмотрения. Garin Kilpatrick считал, что истинным центром учебной работы должна быть активность учащихся, направление которой выбирается самими детьми. Разработанная им система образования и воспитания была основана на интересах ребенка и стимулировании его самостоятельного мышления. Обучение должно происходить в процессе разрешения учеником заинтересовавшей его проблемы, строиться на детских интересах, что и позволит учебному процессу стать эффективным средством формирования нужных обществу моральных качеств подростков. Процесс разрешения учеником заинтересовавшей его проблемы и составляет суть проектной технологии.

Garin Kilpatrick дал следующую характеристику метода проектов: «Это - метод планирования целесообразной (целеустремленной) деятельности в связи с разрешением какого-нибудь учебно-школьного задания в реальной жизненной обстановке. При этом он отмечал, что метод проектов не всегда применим, потому что не всегда имеется возможность пробудить у ребенка достаточно целеустремления. Но в качестве его непревзойденного преимущества он называл тот факт, что в процессе выполнения проекта учащийся длительно, а не мимолетно соприкасается с фактами «лицом к лицу». «Слово проект, - писал он, - быть может, - самый последний посетитель, стучащийся в двери педагогической терминологии. Следует ли пустить этого незнакомца? Да, но под условием, что на два наши предварительных вопроса мы получим убедительные ответы, а именно: во-первых, кроется ли за предлагаемым нам термином «проект» все еще ожидающая крещения серьезная, ценная концепция, обещающая оказать значительную услугу в сфере педагогического 
мышления? Во-вторых, если мы согласны с вышесказанным, то достаточно ли точно термин «проект» выражает ожидаемую концепцию?..» [3].

Garin Kilpatrick искал объединяющую идею, которая должна была найти воплощение в производимой от всего сердца целесообразной деятельности, то есть в сердечном целевом акте. К этому «целевому акту», особенно подчеркивая слово «целевой», он и применил термин «проект». В характеристиках проекта, данных Garin Kilpatrick, ясно прочитывается сущность и воспитательный потенциал метода. «...Если мы при слове «проект» будем представлять себе нечто брошенное, пущенное вперед,... то смысл признания нашего термина выяснится определеннее». Программу школы, работающей по методу проектов, Garin Kilpatrick определял следующим образом: «Программа - ряд опытов, связанных между собой так, что сведения, приобретенные от одного опыта, служат к развитию и обогащению целого потока других опытов». Таким свойством может обладать только деятельность, которая связана с окружающей ребенка реальностью и основывается на актуальных детских интересах. Следует подчеркнуть, что Garin Kilpatrick предлагал строить процесс обучения на основе расширения и обогащения индивидуального жизненного опыта учащихся как организацию деятельности ребенка в социальной среде.

Метод проектов возник как метод организации проектной деятельности детей, метод, стимулирующий собственную активность ребенка, его деятельность целеполагания, актуализирующий его интересы, потребность в самореализации, саморазвитии. Этот вывод подтверждают труды других американских педагогов. Так, Anne Collings в своей книге «Опыт работы американской школы по методу проектов» приводит примеры проектов, выполняемых школьниками в различных разделах учебной программы. Процессу обучения в традиционной школе он противопоставляет совершенно иной подход к учебным занятиям в опытной школе, где выбирается деятельность, занятие, которым учение и учебные предметы подчиняются.

Идея проектного образования раскрывается и у С.И. Гессена, который в »Основах педагогики» обосновал идею конкретно-практической деятельности как исходного пункта обучения. Среди принципов, выделенных С.И. Гессеном применительно к проектному методу обучения можно отнести:

1) образование ориентировано на свободу ребенка и его самоопределение;

2) творчество - основа организации всех занятий (вне творчества урок превращается в механическую процедуру);

3) приоритетны не интересы профессии, а интересы личности; 
4) активность - естественное свойство человека, которое надо постоянно стимулировать;

5) равенство всех в деятельности;

6) образование идет от практики к абстракции, а не наоборот, как это пытается сделать традиционная школа.

В США, Великобритании, Бельгии, Израиле, Финляндии, Германии, Италии, Бразилии, Нидерландах и многих других странах метод проектов нашёл широкое распространение и приобрёл большую популярность в силу рационального сочетания теоретических знаний и их практического применения для решения конкретных проблем окружающее действительности в совместной деятельности школьников.

Метод проектов привлек внимание и русских педагогов еще в XX веке. Идеи проектного обучения возникли в России практически параллельно с разработками американских педагогов. Под руководством Станислава Теофиловича Шацкого в 1905 году была организована небольшая группа сотрудников, пытавшаяся активно использовать проектные методы в практике преподавания. Сторонники метода проектов в советской России В.Н. Шульгин, М.В. Крупенина, Б.В. Игнатьев провозгласили его единственным средством преобразования школы учёбы в школу жизни, с помощью которого приобретение знаний осуществлялось на основе и в связи с трудом учащихся. Однобокое увлечение проектами в ущерб общему развитию личности привело к тому, что уровень общеобразовательной подготовки резко снизился. Современные исследователи истории педагогики выделяют следующие причины:

1) отсутствие подготовленных педагогических кадров, способных работать с проектами;

2) слабая разработанность методики проектной деятельности;

3) гипертрофия метода проектов в ущерб другим методам обучения;

4) сочетание метода проектов с педагогически неграмотной идеей комплексных программ.

Но образовательная политика, построенная на идеях Garin Kilpatrick, привела в 30-е годы к разрушению единого образовательного пространства СССР. Поэтому известным постановлением ЦК ВКП(б) «О педологических извращениях в системе Наркомпроса» метод проектов был осужден, в стране ввели единый учебный план, был осуществлен переход на предметное преподавание основ наук, пятибалльную систему оценки знаний. В центре предметного преподавания находится принцип систематичности обучения, который идеи Garin Kilpatrick попросту разрушали. Поэтому эти идеи и не смогли стать основой новой системы обучения в СССР. С тех пор в России до начала 90-х годов XX века больше 
не предпринимались сколько-нибудь серьезные попытки возродить этот метод в школьной практике.

Начало 90-х годов ознаменовалось сменой общественно-экономической формации в России, разрушением коммунистической идеологии. Произошло изменение взгляда на сущность человека и его роль в обществе. Но смена образовательной парадигмы не повлияла на изменение целей образования и воспитания. Были разрушены традиционные для коммунистической системы механизмы социализации личности ученика, и в связи с этим необходимо было найти адекватную замену механизму социализации, дать ученикам возможность творческой самореализации. И тогда вновь педагогическая общественность вспомнила про метод проектов. В основе метода проектов лежит развитие познавательных навыков учашихся, умений самостоятельно конструировать свои знания, умений ориентироваться в информационном пространстве, развитие критического мышления. Метод проектов всегда ориентирован на самостоятельную деятельность учащихся - индивидуальную, парную, групповую, которую учащиеся выполняют в течение определённого отрезка времени. Этот подход органично сочетается с групповым подходом к обучению.

В современном образовании используются новые педагогические технологии и подходы, успешно внедряются методы развивающего обучения. Ученик становится активным участником учебного процесса, вступает в диалог с педагогом. Они совместно мыслят, решают учебную задачу, возникшую на уроке. Польский педагог Okon считает, что без активности ученика, без его ориентации на познание действительности невозможен процесс мышления. Для А.М. Матюшкина активные методы обучения являются мощным средством развития мышления, открытием новых правил действий в обучении. Существенным в научном творчестве А.М. Матюшкина выделяется его анализ понятия «продуктивный процесс», общим условием которого он считает «проблемную ситуацию», когда у субъекта зарождается потребность открытия новой, еще незнакомой закономерности объекта. Удовлетворение этой потребности и есть познавательная активность. «Продуктивный процесс» включает в себя возникновение познавательной мотивации, субъективное открытие неизвестного. Анализ практики показывает, что преимущество активных методов обучения выражается в возникновении у учащихся желания действовать самостоятельно, вырабатываются необходимые способности, навыки анализа.

Следует различать широкое толкование проекта как понятия и метода проектов. «Метод - это дидактическая категория; совокупность приемов, операций овладения определенной областью практического или теоретического знания, той или иной деятельностью; путь по- 
знания, и способ организации процесса познания». Поэтому, если речь идёт о методе проектов, то имеется в виду именно способ достижения дидактической цели через детальную проработку проблемы. Разработка должна завершиться вполне реальным, осязаемым практическим результатом, оформленным тем или иным образом.

В словаре В.И. Даля даётся следующее толкование слова проект (м. лат.) прожект франц. план, предположение, предначертание; задуманное, предположенное дело, и самое изложение его на письме или в чертеже. Прожектировать что, франц. задумать, загадать, сообразить и предположить к исполнению; составлять для сего записку, чертеж и пр. Прожектирование, действие по глаголу. Прожектёр охотник до проектов, у кого много предположений, задач для исполнения; затейщик, выдумщик.

В словаре С.И. Ожегова даётся толкование слова проект так: (от лат. брошенный вперед) - 1) план, замысел; 2) разработанный план, совокупность документов (расчетов, чертежей и др.) для создания какого-либо сооружения или изделия, 3) предварительный текст какого-либо документа.

Проектировать - составлять проект, делать предположения, намечать план. Поскольку проектирование - деятельность, то для обучения проектированию, безусловно, надо использовать деятельностные формы обучения, такие как метод учебных проектов и любое проектирование как способ организации этой деятельности. Невозможно обучить какой-либо деятельности, не предоставляя возможность осуществлять эту деятельность.

Главная идея проектной деятельности - направленность учебно-познавательной деятельности на результат, который получается при решении практической, теоретической, но обязательно личностно и социально-значимой проблемы. Этот результат называется проект. Каждое из этих значений касается определенной стороны проектной деятельности. Проект - это мысленное предвосхищение, прогнозирование того, что затем будет воплощено в виде предмета, услуги, творческого акта или действия.

В более широком смысле под проектом понимается обоснованная, спланированная и осознанная деятельность, направленная на формирование у школьников определенной системы интеллектуальных и практических умений. Проектная деятельность - это совместная учебно-познавательная, творческая или игровая деятельность, имеющая общую цель, согласованные методы, способы деятельности, направленная на достижение общего результата. Проектная деятельность способствует развитию самостоятельности, целеустремленности, ответственности, настойчивости, толерантности, инициативности, в процессе работы над проектом дети приобретают социальную практику за пределами школы, адаптируются к современным условиям жизни. 
Таблица 1

\begin{tabular}{|c|c|c|}
\hline Термин & $\begin{array}{c}\text { Словарное } \\
\text { значение }\end{array}$ & Педагогическое значение \\
\hline Метод & $\begin{array}{l}\text { способ теоретического } \\
\text { исследования или прак- } \\
\text { тического осуществления } \\
\text { чего-либо }\end{array}$ & $\begin{array}{l}\text { совокупность приёмов, операций овла- } \\
\text { дения определённой областью практиче- } \\
\text { ского или теоретического знания, той или } \\
\text { иной деятельности, способ организации } \\
\text { процесса познания }\end{array}$ \\
\hline Проект & $\begin{array}{l}\text { план, замысел, предвари- } \\
\text { тельный текст документа }\end{array}$ & \\
\hline $\begin{array}{l}\text { Метод } \\
\text { проек- } \\
\text { тов }\end{array}$ & & $\begin{array}{l}\text { способ, в основе которого лежит развитие } \\
\text { познавательных навыков учащихся, крити- } \\
\text { ческого и творческого мышления, умения } \\
\text { самостоятельно конструировать свои знания, } \\
\text { ориентироваться в информационном про- } \\
\text { странстве, увидеть и сформулировать про- } \\
\text { блему. Способ достижения дидактической } \\
\text { цели через детальную разработку проблемы, } \\
\text { которая должна завершиться вполне реаль- } \\
\text { ным осязаемым практическим результатом, } \\
\text { оформленным определённым образом. } \\
\text { Способ, предполагающий решение какой-то } \\
\text { проблемы, предусматривающий использова- } \\
\text { ние разнообразных учебных приёмов и инте-- } \\
\text { грированных знаний из различных областей } \\
\text { науки, техники, творческих областей }\end{array}$ \\
\hline $\begin{array}{l}\text { Про- } \\
\text { блема }\end{array}$ & $\begin{array}{l}\text { задача, требующая разреше- } \\
\text { ния, исследования. Осозна- } \\
\text { ние субъектом невозмож- } \\
\text { ности разрешить трудности } \\
\text { и противоречия, возникшие } \\
\text { в данной ситуации, при } \\
\text { помощи имеющегося у него } \\
\text { знания и опыта. Проблема } \\
\text { берёт своё начало в про- } \\
\text { блемной ситуации } \\
\end{array}$ & $\begin{array}{l}\text { задача, содержащая противоречие, не } \\
\text { имеющая однозначного ответа и требую- } \\
\text { щая поиска решений. Берёт своё начало } \\
\text { в проблемной ситуации }\end{array}$ \\
\hline $\begin{array}{l}\text { Про- } \\
\text { блем- } \\
\text { ная } \\
\text { ситуа- } \\
\text { ция }\end{array}$ & $\begin{array}{l}\text { обстоятельства и условия } \\
\text { деятельности, содержа- } \\
\text { щие противоречия и не } \\
\text { имеющие однозначного } \\
\text { решения, в которых раз- } \\
\text { ворачивается деятельность } \\
\text { индивида или группы } \\
\end{array}$ & $\begin{array}{l}\text { обстоятельства и условия деятельности } \\
\text { учащихся, содержащие противоречия, не } \\
\text { имеющие однозначного ответа }\end{array}$ \\
\hline
\end{tabular}


По своей сути метод проектов близок к проблемному обучению, которое предполагает последовательное и целенаправленное выдвижение перед учашимися познавательных проблем, решая которые они под руководством учителя активно усваивают новые знания. Проблемное обучение обеспечивает прочность знаний и творческое их применение в практической деятельности. Кроме того, метод проектов имеет сходство с развивающим обучением. Развивающее обучение это активно-деятельностный способ обучения, при котором осушествляется целенаправленная учебная деятельность. При этом ученик, являясь полноценным субъектом этой деятельности, сознательно ставит цели и задачи самоизменения и творчески их достигает.

Современная работа в рамках проекта учит младших школьников доводить дело до конца, они должны задокументировать результаты своего труда.

Данная форма организации учебной деятельности имеет ряд достоинств и положительные результаты. Работа над проектом вызывает большой интерес у учащихся, разнообразит урок, помогает развить различные способности, укрепляет межличностные отношения, то есть обеспечивается возможность для развития креативности учащихся.

Исследователи характеризуют метод проектов как: личностно-ориентированный; обучающий взаимодействию в группе и групповой деятельности. Метод, развивающий умения самовыражения, самопрезентации и рефлексии. Это метод, формирующий навыки самостоятельности в мыслительной, практической и волевой сферах. Воспитывает целеустремленность, ответственность, инициативность и творческое отношение к делу. Интегрирует знания, умения и навыки из разных дисциплин; имеет здоровьесберегающий характер.

Анализ развития и использования метода проектов в истории образования показал, что данный метод позволяет органично интегрировать знания учащихся из разных областей при решении одной проблемы, дает возможность применить полученные знания на практике, генерируя при этом новые идеи.

Анализ состояния практики экологического воспитания показал перспективность использования метода проектов как способа организации деятельности детей, построенной на основе их интересов, осуществляемой при активном участии детей в ее планировании и во всех этапах реализации и направленной на формирование у них социально значимого опыта.

Метод проектов - это

1. Способ, в основе которого лежит развитие познавательных навыков учащихся, критического и творческого мышления, умения самостоятельно конструировать свои знания, ориентироваться в информационном пространстве, увидеть и сформулировать проблему. 
2. Способ достижения дидактической цели через детальную разработку проблемы, которая должна завершиться вполне реальным осязаемым практическим результатом, оформленным определённым образом.

3. Способ, предполагающий решение какой-то проблемы, предусматривающий использование разнообразных учебных приёмов и интегрированных знаний из различных областей науки, техники, творческих областей.

В основе метода проектов лежит развитие познавательных навыков учащихся, умений самостоятельно конструировать свои знания, умений ориентироваться в информационном пространстве, развитие критического мышления. Метод проектов всегда ориентирован на самостоятельную деятельность учащихся - индивидуальную, парную, групповую, которую учащиеся выполняют в течение определённого отрезка времени. Этот подход органично сочетается с групповым подходом к обучению.

В основе проекта лежит, какая - либо проблема. Чтобы ее решить учащимся требуется не только знание материала, но и владение большим объемом разнообразных предметных знаний, необходимых и достаточных для решения данной проблемы. Кроме того, школьники должны владеть определенными интеллектуальными, творческими и коммуникативными умениями.

К первым можно отнести умение работать с информацией, с - текстом (выделять главную мысль, вести поиск нужной информации в тексте), анализировать информацию, делать обобщения, выводы и т. п., умение работать с разнообразным справочным материалом.

К творческим умениям психологи относят:

- умение генерировать идеи, для чего требуются знания в разных областях;

- умение находить не одно, а несколько вариантов решения проблемы;

- умение прогнозировать последствия того или иного решения.

K коммуникативным умениям относятся:

- умение вести дискуссию, слышать и слушать собеседника, отстаивать свою точку зрения, подкрепленную аргументами;

- умение находить компромисс с собеседником;

- умение лаконично излагать свою мысль.

Таким образом, для грамотного использования метода проектов требуется значительная подготовка, которая осуществляется, разумеется, в целостной системе обучения в школе (не только в экологическом воспитании).

Итак, основными требованиями к использованию метода проектов являются:

1. Наличие значимой в исследовательском, творческом плане проблемы задачи, требующей интегрированного знания, исследовательского поиска для ее решения. 
2. Практическая, теоретическая значимость предполагаемых результатов.

3. Самостоятельная (индивидуальная, парная, групповая) деятельность на уроке или во внеурочное время.

4. Структурирование содержательной части проекта (с указанием поэтапных результатов и распределения ролей)

5. Использование исследовательских методов: определение проблемы, вытекающих из нее задач исследования, выдвижение гипотезы их решения, обсуждение методов исследования, оформление конечных результатов, анализ полученных данных, подведение итогов, корректировка, выводы_ККроме того, для достижения положительного результата необходимо также учитывать и тип проекта.Чтобы рассмотреть типологию проектов, сначала надо определиться с типологическими признаками. Е.С. Полат [2]. выделяет следующие:

1. Доминирующие в проекте метод или вид деятельности: исследовательский, творческий, ролево-игровой, информационный, практикоориентированный и т. п.

2. Предметно-содержательная область: монопроект (в рамках одной области знания) и межпредметный проект.

3. Характер координации проекта: с открытой, явной координацией (непосредственной) и со скрытой координацией.

4. Характер контактов(среди участников одной школы, одного класса, города, региона, одной страны, разных стран мира): Внутренний, или региональный, и международный.

5. Количество участников проекта(личностные, парные, групповые).

6. Продолжительность проекта (краткосрочный, средней продолжительности, долгосрочный).

В соответствии с признаком доминирующего метода в проекте выделяют следующие типы проектов:

Исследовательские - требуют хорошо продуманной структуры, обозначенных целей, обоснования актуальности предмета исследования всех участников, обозначения источников информации, продуманных методов; полностью подчинены логике небольшого исследования и имеют структуру, приближенную к подлинно научному исследованию.

Творческие проекты - предполагают соответствующее оформление результатов; как правило, не имеют детально проработанной структуры совместной деятельности участников. Оформление результатов - в виде сценария фильма, драматизации, программы праздника, плана сочинения, статьи, репортажа, дизайна и рубрик газеты, альманаха, альбома и т. д.

Ролево-игровые - структура намечается или остается открытой. Участники принимают на себя определенные роли, обусловленные 
характером и содержанием проекта, особенностью решаемой проблемы. Это могут быть литературные персонажи или выдуманные герои.

Информационные проекты - направлены изначально на сбор информации об объекте, явлении; ознакомление участников проекта с этой информацией, ее анализ и обобщение фактов; требуют хорошо продуманной структуры, возможности систематической корректировки по ходу работы над проектом.

Практико-ориентированные проекты - четко обозначенный результат деятельности участников проекта, который обязательно ориентирован на социальные интересы самих участников (документ, созданный на основе полученных результатов исследований, программа действий, проект закона, словарь, дизайн дома и т. п.)

По признаку предметно-содержательной области проекта:

Монопроекты - проводятся в рамках одногоучебного предмета. Межпредметные проекты - выполняются во внеурочноевремя. Это могут быть небольшие проекты, затрагивающие два - три предмета, атакже достаточно объемные, продолжительные, общешкольные.

И. Чечель выделяет также и надпредметные проекты, которые выполняются в ходе факультативов, изучения интегрированных курсов, работы в творческих мастерских [3].

По характеру координации:

С открытой, явной координацией - координатор проекта участвует в проекте в собственной функции, ненавязчиво направляя работу его участников, организуя в случае необходимости отдельные этапы проекта, деятельность его отдельных участников.

Со скрытой координацией - координатор выступает как полноправный участник проекта.

По характеру контактов:

Внутренние (региональные) проекты - организуются или внутри одной школы, на уроках по одному предмету, или междисциплинарные, или между школами внутри региона, страны.

Международные проекты - участниками проекта являются представители разных стран.

По количеству участников проекта:

Личностные - между двумя партнерами, находящимися в разных школах, регионах, странах.

Парные - между парами участников.

Групповые - между группами. В данном случае очень важно правильно с методической точки зрения организовать эту групповую деятельность участников проекта. 


\section{По продолжительности проведения:}

Краткосрочные - для решения небольшой проблемы или части более значимой проблемы; проводятся на уроках по отдельному предмету иногда с привлечением знаний из другой учебной дисциплины.

Средней продолжительности и долгосрочные - от одного-двух месяцев до года; являются междисциплинарными и содержат достаточно значимую проблему или несколько взаимосвязанных проблем, могут представлять собой целостную программу; проводятся во внеурочное время.

В реальной практике чаще всего приходится иметь дело со смешанными типами проектов, в которых имеются признаки исследовательских и творческих проектов, например, одновременно, практико-ориентированные и исследовательские.

Каждый тип проекта имеет тот или иной вид координации, сроки исполнения, этапность, количество участников. Поэтому, разрабатывая проект, надо иметь в виду признаки и характерные особенности каждого из них. Знание учителем типологии проектов позволит ему не замкнуться на каком-то одном типе проекта и сделать работу по методу проектов более разнообразной.

В зависимости от темы проекта и интересов школьников состав учащихся может меняться. Что касается количественного состава группы, то наиболее успешно разрабатывает проект группа из 3-4 человек. Учащиеся предлагают свои темы проекта.

Нельзя также забывать и о том, что работа над проектом проводится в несколько этапов. В зависимости от планируемого результата (плакат, чертеж, выставка фотографий и рисунков, газета и т. д.) данная работа может занимать несколько уроков. Кроме того, учащиеся получают домашние задания поискового характера. Такие задания предполагают самостоятельную работу с дополнительной литературой, прослушивание радиопередач, интервьюирование одноклассников, учителей, родителей.

Проект предполагает следующие этапы работы:

1 - работа над темой цикла (чтение текстов по теме, активизация материала в упражнениях). На данном этапе учитель может использовать различные творческие задания, такие как: сочинения, ролевые игры, которые в последствии могут войти в основу проекта. Они подготовят учащихся к дальнейшей работе и повысят мотивацию к творческой деятельности.

2 - обсуждение темы будущего проекта. Учащиеся ищут ответы на вопросы проблемного характера в материалах учебника, отстаивают свои мотивы работы над будущим проектом.

3 - формирование творческих групп, распределение заданий между членами группы, работа над планом проекта. Одному из учащихся, 
например, поручают нарисовать рисунок, другому - собрать фактический материал и т. д.

4 - сбор дополнительной информации. Школьники используют не только тексты учебника, но и материалы периодической печати, журналы, энциклопедии.

5 - оформление проекта(рисунки, поделки). Одни проекты школьники оформляют дома самостоятельно, другие, требующие большей помощи со стороны учителя, создаются в классе. Главное - не подавлять инициативу ребят, с уважением относиться к любой идее, любому предложению, помогать, но не диктовать, не навязывать свою точку зрения.

6 - презентация проекта. Это очень ответственный этап работы праздник для ребят. Ведь весь отобранный, оформленный материал надо так ярко и эмоционально представить, чтобы заинтересовать одноклассников, для которых каждый проект их товарищей - сюрприз.

7 - подведение итогов работы. Очень важно на данном этапе дать возможность учащимся выразить свое мнение, обменяться впечатлениями. Самые яркие, оригинальные, содержательные проекты поощряются.

Таким образом, работа над проектом предполагает создание максимально благоприятных условий для раскрытия и проявления творческого потенциала, учащихся вообще, и для развития творческих способностей в частности: развивает их воображение, фантазию, мышление. При этом формируется внутренний мотив говорения, возникает необходимость чтото, сказать, которая диктуется желанием принять участие в общении.

Конечно, выполнение заданий проекта выходит за рамки урока и требует много времени, но часто усилия оправдывают себя, так как при этом решается ряд важных задач $[3,8]$ :

- Занятия не ограничиваются приобретением учащимися определённых знаний, умений, навыков, а выходят на практические действия учеников, затрагивая их эмоциональную сферу, благодаря чему усиливается мотивация учащихся при изучении природоведения.

- Учащиеся имеют возможность осуществлять творческую работу в рамках заданной темы, самостоятельно добывая необходимую информацию, не только из учебников, но и из других источников.

- В проекте успешно реализуются различные формы организации учебной деятельности, в ходе которых осуществляется взаимодействие учащихся друг с другом и учителем, роль которого меняется: вместо контролера он становится равноправным партнером и консультантом.

- В проектной работе весь учебный процесс ориентирован на учащегося:

- Здесь, прежде всего, учитываются его интересы, жизненный опыт и индивидуальные способности. 
- Усиливается индивидуальная и коллективная ответственность учащихся за конкретную работу в рамках проекта, так как каждый учащийся, работая индивидуально или в микрогруппе, должен представить всей группе результаты своей деятельности.

- Современная работа в рамках проекта учит младших школьников доводить дело до конца, они должны задокументировать результаты своего труда.

- Деятельность учащихся основывается на групповом взаимодействии, которое является не только формой обучения, но и естественным компонентом учебного процесса.

В процессе исследовательской деятельности расширяется образовательный кругозор учащихся, возрастает стойкий познавательный интерес к знакомству с разными отраслями научного познания, естественным становится участие в диалоге культур, в известном смысле формируется уровень профессионального общения, широкий взгляд на мир как на единую культурную, экологическую среду обитания в масштабе всей планеты [3].

Данная форма организации учебной деятельности имеет ряд достоинств и приносит положительные результаты: работа над проектом вызывает большой интерес у учащихся, разнообразит урок, помогает развить различные способности, укрепляет межличностные отношения, т. е.обеспечивается возможность для развития креативности учащихся.

Современное общество ставит перед школой новые задачи: воспитание человека умелого и мобильного; умеющего самостоятельно добывать, обрабатывать полученную информацию; способного успевать за стремительным развитием цивилизации. Поэтому начальная школа, которая решает задачи развития базовых способностей ребёнка, формирует главные инструменты познания, должна решать проблему формирования ключевых компетенций учащихся, в частности, учебно-познавательной, информационной, коммуникативной как условие достижения качественных результатов на следующих ступенях обучения [6]. В новых ФГОС большое внимание уделяется именно проектной и исследовательской деятельности как решающему фактору в формировании у школьника умения учиться. В основе метода проектов лежит развитие познавательных навыков учащихся, умений ориентироваться в информационном пространстве, развитие критического и творческого мышления. Проект - форма организации совместной деятельности людей. Проект - это специально организованный учителем и самостоятельно выполненный учащимися комплекс действий, завершающихся созданием творческого продукта. Проект - это «Пять П»: проблема, 
проектирование (планирование), поиск информации, продукт, презентация. Проект многогранен, эффективен, неисчерпаем.

Занимаясь проектной деятельностью, учащиеся учатся:

1) размышлять, опираясь на знание фактов, закономерностей науки;

2) делать обоснованные выводы;

3) принимать самостоятельные аргументированные решения;

4) работать в команде, выполняя разные социальные роли.

Младший школьный возраст - благоприятный и значимый период для выявления и развития творческого потенциала личности, так как в этом возрасте закладываются основы творческой и образовательной траектории, психологическая база продуктивной деятельности, формируется комплекс ценностей, качеств, способностей, потребностей личности, лежащих в основе её творческого отношения к действительности [1]. Поэтому развивать заложенную в каждом ребёнке творческую активность, воспитывать у него необходимые для этого качества - значит, создавать педагогические условия, которые будут способствовать этому процессу.

В ходе выполнения проекта школьники учатся самостоятельно приобретать знания, получают опыт познавательной и учебной деятельности.

Именно в 1 классе формируются общеучебные умения и навыки, которые способствуют достижению качественных результатов в обучении и воспитании. Для того чтобы сделать проектную деятельность действительно полезной для развития школьников необходимо основы исследовательской деятельности заложить уже в 1 классе. Ведущая идея опыта, положенная в основу решения выдвинутой задачи: личностнодеятельностный подход, предполагающий максимальное раскрытие потенциальных возможностей личности в деятельности, обращенность к внутреннему миру ребёнка; для реализации поставленной задачи разработана методика по эффективному включению учащихся в проектную деятельность.

Данная методика представлена тремя блоками. Рассмотрим их более подробно.

1 блок - разработка заданий, подготавливающих учащихся к работе над проектом:

- доконструирование (продолжи рассуждения товарищей, закончи рассказ). Дети учатся высказывать свои мысли, слушать высказывания одноклассников, устанавливать связи, т. е. цель данных заданий - развитие коммуникативных умений;

- переконструирование (перескажи от первого лица, от имени героя сказки, рассказа). Ребёнок учится разным социальным ролям, учится 
представлять ситуацию с разных сторон. Цель этих заданий - развитие системного мышления.

- собственное конструирование (составь рассказ, кроссворд.) Такие задания позволяют создавать условия для самостоятельного охотного приобретения знаний из различных источников информации. Цель данных заданий - формирование информационных умений. В ходе выполнения таких заданий учащиеся постепенно приобретают навыки самостоятельной исследовательской деятельности.

2 блок - разработка проектных игр.

Наряду с предложенными заданиями в 1 классе используются проектные игры, в ходе которых дети приобретают навыки переноса знаний из учебной ситуации в реальную жизнь, развивают коммуникативные навыки.

В групповой проектной работе распределяются роли и определяются обязанности, рассмотрим это в табл. 2.

Таблица 2

Распределение ролей при работе над проектом

\begin{tabular}{|l|l|}
\hline \multicolumn{1}{|c|}{ Роль } & \multicolumn{1}{c|}{ Обязанности } \\
\hline Исследователь & $\begin{array}{l}\text { отыскивает все новое, необычное, таинственное, разгадывает } \\
\text { найденные загадки, отвечает за сбор информации }\end{array}$ \\
\hline Творец & создает новые произведения, сочиняет, оформляет \\
\hline Помощник & $\begin{array}{l}\text { помогает налаживать коммуникации, оказывает поддержку } \\
\text { другим участникам проекта }\end{array}$ \\
\hline Организатор & следит за этапами выполнения работы, ведет запись работы \\
\hline Докладчик & готовит доклад о работе, отвечает за этап презентации \\
\hline
\end{tabular}

Роли и обязанности педагог может добавлять и изменять. Тематика игр может быть следующей. «Что нам стоит дом построить». «Семь Я». «Эти забавные животные». «Грамотейка». «Мы исследуем школу». «Наша планета».

Демонстративный, артистичный ребенок, которому может не даваться систематичная работа, связанная с этапом сбора или переработки информации, прекрасно покажет себя на презентации проекта; не особо успешный в учебной деятельности, но добрый и отзывчивый ребенок будет незаменим в роли помощника. В групповой проектной работе роль и возможность показать себя с наилучшей стороны найдется для каждого. Регулируя распределение ролей в значимой для детей деятельности - в процессе работы над проектом - с учетом индивидуальных особенностей каждого ребенка, педагог - руководитель проекта получает возможность оказывать влияние на отношения в детском коллективе. 
3 блок - разработка серии детских проектов.

Продуктивность проектной деятельности младшего школьника предусматривает готовность к процессу взаимодействия. Выяснять точки зрения по определённому вопросу. Обращаться за помощью к другим в случае дефицита информации. Формулировать своё мнение, доказывать его. Ребёнок должен управлять собой, выбирая в доброжелательной атмосфере самое верное, рациональное, оригинальное решение, уметь управлять своим голосом, мимикой и жестами [6].

Для учителя самым ценным в методе проектов является сам процесс работы, т. к. он представляет собой инструмент, дидактическое средство обучения и воспитания. Учащиеся в большей степени заинтересованы в результате работы. Найти разумный баланс этих интересов позволяет правильно выбранный вид проекта. Подбирая определённый вид проекта, учитель, может управлять активностью учащегося на протяжении всего периода работы над проектом, формируя у него, таким образом, необходимые предметные знания и умения, общеучебные умения и навыки, необходимые компетентности [3].

В начальной школе используются следующие виды проектов.

1. Информационные проекты. Его цель: сбор, оформление и предоставление информации. В проекте любого типа есть этап сбора информации, но там это только средство работы, а в информационном проекте это - цель. Для ученика доминирующей стороной деятельности здесь будет именно работа с информацией и, соответственно, развиваться и совершенствоваться у него будет в основном именно информационная компетентность. Данный вид проекта позволяет развивать у ребёнка навыки работы с информацией, умение анализировать тексты, ранжировать и проверять сведения из различных источников [6]. Для самых маленьких - это работа с детской книгой, словарём, детскими журналами. Поиск стихотворений, пословиц на заданную тему, подбор информации используя интернет.

Информация о жизни домашних животных, птиц, комнатных растений - все это может вылиться в проекты в начальной школе. Тем более что ведение дневников наблюдений - основа проекта. Правило записывать все проекты в особые тетради, фиксировать ход работы над проектом и конечным результатом и конечные результаты работы, дает достаточно материала для упражнений в письме и счете. Правда, это возможно тогда, когда человек умеет читать и писать. До этого момента итогом наблюдений становится устный рассказ или рисунок. Темы: «Как люди приветствовали друг друга?» «Почему их так назвали - подсолнух, колокольчик, одуванчик?» «Однажды я был с мамой в зоопарке». 
Выходом такого проекта часто является публикация в СМИ, в Интернете. Результатом такого проекта может быть и создание информационной среды класса или школы. Предметная область - окружающий мир, литературное чтение, внеклассная работа.

2. Исследовательские проекты. Для развития аналитических способностей, критического мышления, освоения логических способов восприятия и обработки информации в большей степени подходят исследовательские проекты. Целью учащегося в данном случае является доказательство или опровержение гипотезы проекта. Для этого ему потребуется проводить эксперименты, анализировать их результаты, обобщать, сравнивать, выявлять закономерности, проводить аналогии, а также делать выводы, обосновывать свою точку зрения. Таким образом, основной упор будет сделан на мыслительную компетентность. Идея исследовательского проекта достаточно многогранна. При этом используются методы современной науки: лабораторный эксперимент, моделирование, социологический опрос и другие. Для работы над исследовательским проектом необходима помощь взрослых (родителей), потому что дети не способны к длительной самостоятельной работе без участия взрослых, их поддержки, помощи, анализа и нацеливания на работу [3].

В результате исследовательских проектов могут создаваться как научные статьи, брошюры, так и модели или макеты, учебные фильмы и компьютерные презентации, учебная экскурсия или доклад. Образовательная область - литературное чтение, окружающий мир, изобразительное искусство, внеклассная работа.

3. Творческие проекты. Самый большой простор предоставляет проектная деятельность для развития творческих способностей. Творческий проект позволяет учащемуся проявить себя, создав произведение любого жанра. Такие проекты способны кардинальным образом изменить представление окружающих об авторе проекта, поднять его статус в классе, снизить тревожность, повысить самооценку, не говоря уже о непосредственном развитии творческих способностей ребёнка. Любое творческое произведение нуждается в презентации и обратной связи с аудиторией (зрителями, слушателями, читателями), поэтому основное развивающее воздействие будет оказано на коммуникативную компетентность. Сюда относится изготовление материальных предметов преимущественно на уроках труда или во внеклассной работе. Изготовление поздравительных открыток, книжных закладок, игрушек, сувениров, предметов школьного обихода. Ведущей идеей такого проектирования является идея «самообслуживания». Творческие проекты чаще всего завершаются созданием 
произведений искусства различных жанров или проведением творческих мероприятий [3].

Данный вид проекта предполагает максимально свободный и нетрадиционный подход к оформлению результатов. Это могут быть альманахи, театрализации, спортивные игры, произведения изобразительного или декоративно-прикладного искусства, видеофильмы и т. п. Темы творческих проектов могут быть следующими. «Картонажный театр кукол с подвижным соединением деталей». «Кто в аквариуме живёт» (оригами). «Закладка для любимой книжки». «Объёмная композиция» (герои сказок). «Мастерская Деда Мороза». Образовательная область - трудовое обучение (технология), изобразительное искусство, внеклассная работа.

4. Ролевые проекты, в том числе игровые проекты. Целью автора такого проекта является вовлечение публики (детей и взрослых) в решение проблемы проекта. Чтобы добиться этого, придётся не просто искать информацию или создавать произведение искусства, нужно будет организовать деятельность других людей, вовлечь их в работу, сделать её интересной для всех. Особенно это важно для замкнутых, застенчивых детей освоить эти умения, приобрести или усовершенствовать свою коммуникативную компетентность. Важен момент проектирования игр, подготовка к ним, изготовление самими учениками принадлежностей. Разработка и реализация такого проекта наиболее сложна. Участвуя в нем, проектанты берут на себя роли литературных или исторических персонажей, выдуманных героев и т. п. Результат проекта остается открытым до самого окончания. Игровые и ролевые проекты всегда связаны с проведением мероприятий, которые в этом случае являются проектным продуктом, так как публика привлекается к решению проблемы проекта.

Приступая к проектированию с младшими школьниками, следует учесть, что большинство малышей ещё не имеют постоянных увлечений. Их интересы ситуативны. Поэтому, если тема проекта выбрана, приступать к её выполнению надо немедленно, пока не угас интерес. Затягивание времени может привести к потере мотивации к работе, неудачному результату, незаконченному проекту и отвращению к участию в каких либо проектах в дальнейшем. Следовательно, выполнять исследование надо на одном дыхании из-за отсутствия у младших школьников способности долговременно и целенаправленно работать в одном направлении. Отсюда вытекает ещё одно условие, которое должно быть соблюдено при организации проектной деятельности младших школьников: максимально возможное дидактическое, информационное и материальное обеспечение проектной деятельности прямо в школе. 
Отсутствие необходимой исследовательской базы, невозможность собрать необходимые данные обычно приводят к поверхностному решению, порождают пустословие. Для решения данной задачи в школе может быть создан специально «Центр обогащения содержания образования», где собирается и хранится всё, что может пригодиться для детских проектов и исследовательской работы: справочная литература, рисунки, схемы, видеокассеты, приборы, игрушки, камни, палочки, кусочки ткани и т. д. Ценность этого центра для начинающих исследователей очень высока. Задача ребёнка собрать материал из книг и других источников по заранее предложенным темам, которые связаны с трудовым обучением, окружающим миром, литературным чтением, изобразительным искусством. Несложность проектов обеспечивает успех их выполнения и является стимулом, вдохновляющим ученика на выполнение других, более сложных проектов.

Таким образом, можно выделить следующие основные направления реализации метода проектов в экологическом воспитании детей младшего школьного возраста.

Исследовательский проект имеет цель: доказательство или опровержение какой-либо гипотезы. Деятельность учащихся, связанная с экспериментированием, логическими мыслительными операциями. Проектным продуктом данного вида будет результат исследования, оформленный установленным способом.

Цель информационного проекта - сбор информации о каком-либо объекте или явлении. Деятельность учащихся в данном виде проекта связана со сбором, проверкой, ранжированием информации из различных источников; общение с людьми, как источниками информации. Продукт деятельности информационного проекта - статистические данные, результаты опросов общественного мнения, обобщение высказываний различных авторов по какому-либо вопросу.

Целью творческого проекта является - привлечение интереса публики к проблеме проекта. Учащиеся проявляют творческую деятельность, связанную с получением обратной связи от публики. Продукт деятельности - литературные произведения, произведения изобразительного или декоративно-прикладного искусства, видеофильмы.

Игровой или ролевой проект имеют цель: предоставление публике опыта участия в решении проблемы проекта. Деятельность учащихся, связанная с групповой коммуникацией. Проектным продуктом является мероприятие (игра, состязание, викторина, экскурсия и тому подобное).

Рассмотрим методические аспекты реализации метода проектов в экологическом воспитании детей младшего школьного возраста. 
Знание теории не всегда подтверждается умением работать практически в интересуемой области знаний.Работа по экологическому воспитанию заключается в формировании экологического сознания, через формирование экологических представлений и убеждений.

Исследование школьниками реальной жизни в процессе урочной деятельности, а также в процессе внеклассной работы, дает материал для обсуждения разнообразных жизненных ситуаций в природной среде, особенно поведения людей, где результат не соответствует желаемому. Это позволяет школьникам извлекать уроки на будущее, изменять цели своей деятельности, принимать решение в соответствии с убеждениями. Естественнонаучные знания при этом обосновывают оптимальные способы поведения и действий в окружающей среде.

В содержании экологического образования в начальной школе должны найти отражение материалы из различных отделов экологии. Наибольшие возможности для этого имеет раздел по экологии биологических систем. Особый интерес у младших школьников вызывает материал об отношениях живых организмов со средой обитания. Содержание этого раздела близко и понятно детям. Оно дает представление о многообразии обитателей природы, о том, как они приспосабливаются к условиям жизни (к сезонным изменениям, к условиям обитания, к взаимоотношениям собой и человеком). Дети узнают, где живут животные, какое влияние оказывает на них человек и его деятельность и как уменьшить вредное воздействие этой деятельности на сохранение многообразия видов растений и животных.

Младших школьников нужно подвести к выводу, что от состояния окружающей среды зависит состояние здоровья человека, а поэтому оберегать эстетические, экологические, санитарно-гигиенические качества окружающей среды - значит заботиться о здоровье человека, его нормальной жизнедеятельности. На начальном этапе обучения имеется возможность познакомить детей с предметами, созданными трудом человека. Знакомство со средой населенных мест. Это позволит показать роль труда в преобразовании природного окружения, как с положительной, так и с отрицательной сторон. На основании этого наметить пути гармонизации (оптимизации) отношений человека с природным и социальным окружением.

Большую роль в образовании и воспитании школьников, в том числе и младших, играет практическая работа в природных условиях. Теоретические знания, полученные на уроках, становятся базой для самостоятельной оценки происходящих в природе процессов и явлений для проведения собственных исследований, наблюдений, умения обобщить результаты своих наблюдений, способствовать грамотному, безопасному для природы и собственного здоровья поведению. 
K сожалению, часто уроки окружающего мира ограничиваются стенами классной комнаты. Несмотря на то, что младшие школьники, естественно, не знают достаточно глубоко промышленного и сельскохозяйственного производства, не могут судить в полном объеме о физическом и химическом загрязнении окружающей среды, отдельные вкрапления таких знаний должны иметь место в занятиях внеклассной работы по экологическому воспитанию. Проектная деятельность помогает комплексно реализовать ряд психолого-педагогических принципов: научности, комплексности, системности, систематичности и последовательности работы (этапности), доступности материала, наглядности, учёта возрастных, индивидуальных и личностных особенностей воспитанников, мотивации, сотрудничество детей и взрослых. Учитывая особенности детей данного возраста, за основу в работе по экологическому воспитанию необходимо была выбирать проектную деятельность.

Исследовательский проект может рассматриваться как дополнение к существующим программам, может быть выделен в качестве факультативных занятий. Опыт показывает, что учащиеся младших классов с удовольствием и большим интересом участвуют в такой работе, естественно на доступном для них уровне [2].

Исследовательский проект предусматривает определённую последовательность действий: определение проблемы, выдвижение гипотезы, обсуждение методов исследования, анализ полученных данных, оформление конечных результатов (презентация, защита, демонстрация).

В младшем возрасте у детей преобладает чувственное, образное восприятие окружающего мира, что обязательно должно учитываться при разработке методики работы с детьми. Приведем пример проекта «Зимующие птицы - наши друзья», который может быть использован в 1 классе. Данный проект подразумевает выполнение детьми следующих заданий: проведение наблюдений, обобщение результатов наблюдений в самой разнообразной форме и составление рекомендаций по проблеме. Актуальность проекта: большое количество птиц гибнет в зимние холода, человек может помочь им пережить стужу.

Разработка проекта начинается с постановки цели. Цель данного проекта: изучение проблемы жизни зимующих птиц, наблюдение за ними, их подкормка.

Задачи проекта:

1) научить учащихся самостоятельно собирать необходимую информацию;

2) проводить работу по изучению жизни и поведения зимующих птиц; 
3) проводить регулярные наблюдения за кормушками в течение зимних месяцев, фиксировать наблюдения в дневнике;

4) помочь птицам пережить холода.

Можно выделили подтемы в проекте в зависимости от объектов наблюдений: «Воробей домовой». «Синица большая». «Снегирь». «Голубь сизокрылый». «Ворона, сорока».

Реализация проекта проходит ряд этапов.

1. Подготовительный этап как первая ступень проектной деятельности: изучение теоретического материала, обзор литературы о птицах; создание кормушек; выбор места для кормушек.

2. Реализация проекта. Наблюдение как вторая ступень проектной деятельности (наблюдение, анализ, сравнение, обобщение). Создание дневника наблюдений. Детям может быть предложена тема проекта «Зимуюшие птицы - наши друзья»«, сформулирована проблема проекта: «Сможет ли человек помочь зимующим птицам и как?». Затем учащиеся осуществляют поисковую деятельность, отвечают на поставленные вопросы и оформляют дневник наблюдения, планируя свою работу с помощью учителя и родителей. На данном этапе должна проводится: ежедневная подкормка птиц, наблюдение за их поведением, использование разных кормов, учёт количества птиц, их видов; наблюдение активности птиц в зависимости от погодных условий и этапов светового дня, заполнение общего дневника наблюдений. На основе группового обучения проектной деятельности, могут определится дети, которые смогут самостоятельно создать индивидуальные «Дневники наблюдений», научиться составлять презентацию по итогам наблюдений.

3. Рефлексия. Представление результатов работы - это третья ступень проектной деятельности. По окончанию работы над проектом необходимо подвести итоги наблюдения: чему научились, что узнали нового. Следует подвести детей к формулировке выводов о том, что птицы становятся заметными и более активными с приходом тепла: чем ярче светит солнце, чем теплее, тем больше птиц на улице, тем они активнее; в ветреные дни птицы не прилетают в малом количестве; из кормов голуби и воробьи предпочитают крошки от хлеба, семена подсолнуха, семена льна, а синицы - сало; воробьи и голуби прилетают стайками, а синички - по 2-3; кормушки посетили 3 вида птиц. Это воробьи, синицы, голуби, снегири (редко). За время действия проекта птицы привыкли получать корм, поэтому подкормку необходимо продолжить. Узнав много нового о птицах, дети стали совершенно подругому относиться к ним. Ведь теперь они знают, чтобы птицам не замерзнуть в морозы, их надо накормить. 
В период данного проекта можно изготовить при помощи родителей кормушки, затем кормушки развесить в школьном парке, провести конкурс рисунков «Птицы наши друзья», классный и библиотечный час о зимующих птицах, провести акцию-призыв «Помогите птицам!» через оформление общешкольного стенда.

Таким образом, исследовательский проект играет большую роль в воспитании, образовании младшего школьника, развивает умение искать путь решения поставленной задачи, развивает творческие способности, повышает мотивацию к обучению, способствует формированию новых взаимоотношений сотрудничества между учителем и учениками. Большую роль в экологическом воспитании младших школьников играет практическая, исследовательская работа в природных условиях. Наблюдение окружаюшей действительности оказывает глубокое воздействие на всестороннее развитие личности ребенка.

Рассмотрим методику работы с информационным проектом.

Информационный проект направлен на сбор информации о какомлибо объекте, явлении с целью её анализа, обобщения и представления для широкой аудитории. В 1 классе информационные проекты можно осушествлять через проведение экскурсий. Программа в начальной школе насыщена экскурсиями. Целью экскурсии является поиск ответа на вопрос, поиск предполагает анализ какого-либо одного исследуемого предмета или явления. Проекты данного вида ставят перед детьми конкретные вопросы, ответы на которые они должны получить самостоятельно. Итоги проектов обязательно должны обсуждаться, дети рассказывают о своих впечатлениях, учатся анализировать, обобщать [2]. Во время каждой экскурсии необходимо делать фоторепортаж.

Рассмотрим алгоритм работы над информационным проектом.

1 этап - подготовительный. Он состоит из: определения источников информации; изучения дополнительной литературы, получения дополнительной информации; формирования рабочих групп.

2 этап - планирование. На данном этапе осуществляется: выработка групповых и индивидуальных планов работы; определение задач, источников и способов сбора информации для каждой группы; распределение задач и обязанностей между членами групп; определение способов предоставления результатов работы.

3 этап - исследование. Сюда входит работа в библиотеке с различными источниками. Сам процесс исследования. Проведение экскурсий. Анализ информации, сопоставление, формулировка выводов.

4 этап - рефлексия. Здесь ребята подводят итоги своей работы, представляют презентации. 
Например, проект на тему: «Капелька» может быть реализован в 1 классе.

Цель проекта: ознакомление учащихся со значением воды в жизни живых существ и для здоровья человека.

Задачи проекта:

1) развивать познавательные способности детей в процессе совместной исследовательской деятельности, практических опытов с водой;

2) систематизировать и расширить знания учащихся о воде;

3) формировать навык участия в коллективной деятельности, учить оценивать свой вклад в общий результат;

4) развивать логическое мышление, умение добывать нужную (доступную) информацию, работать с дополнительной литературой, анализировать, делать выводы;

5) воспитывать умение слушать и слышать друг друга, уважительное отношение к мнению других, взаимопомощь, самостоятельность, инициативность, интерес и любовь к предмету;

6) воспитывать любовь и бережное отношение к природе.

На первом этапе работы учеников разделяют на группы.

1 группа «Следопыты»

2 группа «Литераторы»

3 группа «Исследователи»

На втором этапе проекта даются задания для каждой группы, предлагаются вопросы, на которые надо найти ответы.

1 группа «Следопыты»:

1. Выяснить физические свойства воды: цвет, запах, виды состояния воды.

2. Узнать у родителей, что такое родниковая вода.

3. Совершить экскурсию с родителями к роднику, сделать фотоматериал.

4. Нарисовать рисунки.

5. Сделать сообщения о своих наблюдениях, полученных знаниях, опытах.

2 группа «Литераторы»:

1. Найти произведения (стихи, сказки, загадки, песни о воде).

2. Совершить экскурсию с родителями к реке.

3. Выяснить особенности речной воды, сделать фотоматериал.

4. Нарисовать рисунки.

5. Сделать сообщения о своих результатах: выпуск книжки-малышки.

3 группа «Исследователи»:

1. Провести опыт «Изменение физического состояния воды от изменения температуры воздуха» 
2. Совершить экскурсию с родителями с целью наблюдения изменения физического состояния воды (утром, днём, вечером в теплый весенний день).

3. Нарисовать рисунки.

4. Сделать сообщения о результатах наблюдений, экскурсий.

На третьем этапе ребята выполняют задания, анализируя информацию. Творческий отчёт готовит каждая группа, где «кураторами» являются родители. На итоговом мероприятии подводят итог о том, что вода главная составляющая всего живого. Без воды нет жизни на Земле.

На четвертом этапе - рефлексии - подводят итоги о том, интересно ли было работать в группах; в какой группе работа была более успешной; какие трудности испытали во время работы. Что удалось лучше, что не получилось пока; что же изменилось в представлении детей о воде. По итогам данного проекта может быть создана книга «Капелька», оформлен экологический плакат «Судьба капельки».

\section{Методика работы с творческим проектом}

Творческий проект предполагает максимально свободный и нетрадиционный подход к оформлению результатов. Это могут быть альманахи, театрализации, спортивные игры, произведения изобразительного или декоративно-прикладного искусства, презентации, видеофильмы.

Структура проектирования состоит из следующих этапов:

1. Организационно-подготовительный этап. Он включает в себя поиск проблемы, обоснование выбора изделия, выбор и анализ материалов и инструментов для выполнения изделия, анализ предстоящей работы, определение критериев, контроль качества, организация рабочего места. На этом этапе перед школьниками ставится проблема. Школьники должны уяснить, зачем и почему им надо выполнять данный проект, какова основная задача предстоящей работы. Возникающие образы будущего изделия должны найти воплощения в эскизах и рисунках.

2. Технологический этап. Его цель: качественное и правильное выполнение трудовых операций, деятельностный контроль и самооценка работы.

3. Заключительный этап. На этом этапе осуществляется защита проекта, его оценка. Все учащиеся выступают со своими проектами, демонстрируют, что достигнуто, определяют дальнейшие перспективы, отвечают на вопросы одноклассников, производят самооценку проекта.

Представим вариант творческого проекта для первоклассников по теме «Подводный мир», образовательная область технология.

Цель: развитие общетрудовых и специальных знаний, умений и навыков учащихся. 
Задачи:

1) формирование понятия об изготовлении поделок в технике ремейк;

2) развитие умения составлять план происходящей работы;

3) развитие умения работать в парах;

4) развитие творческих способностей учащихся.

Проект предполагает изготовление поделок в технике ремейк. В ходе проекта происходит работа с разными материалами и готовыми формами.

Оборудование: видеофильм с записью подводного мира; мелодии с записью инструментальной музыки; отличительные флажки для каждой бригады; рисунки героев из сказки «Русалочка»; инструкционные карты по правилам работы с ножницами; карточки-заготовки для составления алгоритма предстоящей деятельности: деревянные рамочки для оформления поделок.

Этапы реализации проекта следующие: организационный момент, постановка учебной задачи, знакомство с техникой ремейк.

Работа проводится в парах. Каждая бригада выполняет только одну поделку, разрабатывая свой творческий проект.

На доске учитель составляет алгоритм выполнения работы. Учащиеся составляют план работы, который поможет им в ходе работы над проектом. Каждый шаг алгоритма обсуждается в паре, дети приходят к единому мнению и только после этого выполняют работу.

Алгоритм выполнения творческой работы

1. Выявление проблемы Готовая продукция

2. Поиск решения проблемы

Обсудите в парах, что можно сделать, и придите к одному решению

3. Разработка поделки

Нарисуйте эскиз вашей поделки

Во время выполнения работы учащиеся в парах обсуждают свои предложения и рисуют эскиз будущей поделки. А затем делают саму поделку («Медузу», «Рыбу», «Осьминога», «Звезду», «Краба»). После выполнения практической части, детям необходимо составить небольшой рассказ для защиты своей работы: для этого они используют словари, интернет.

Рефлексия. Представитель каждой пары выходит к доске и защищает свой проект. Участники других пар высказывают свои предложения по усовершенствованию изделия, что больше понравилось в работе.

Таким образом, метод проектов, критически переработанный, сможет обеспечить развитие творческой инициативы и самостоятельности учащегося в процессе обучения, поможет найти способы, пути развития самостоятельного мышления ребенка, позволит научить его не просто 
запоминать и воспроизводить знания, которые дает школа, но и уметь применить эти знания на практике. При этом активность ребенка строится на основе свободы, а роль учителя сводится к руководству самостоятельной работой учащихся и пробуждению их пытливости. А в совокупности это способствует экологическому воспитанию младших школьников.

\section{Библиографический список:}

1. Николаева С.Н.Теория и методика экологического образования детей: Учеб. пособие для студ. высш. пед. учеб.заведений - М.: Изд. центр «Академия», 2002. - $336 \mathrm{c.}$

2. Переверзев Л.Б. Метод учебных проектов в образовательном учреждении: Пособие для учителей и студентов педагогических вузов. М.: АРКТИ, 2007. - 257 с.

3. Полат Е.С., Бухаркина М.Ю., Моисеева М.В., Петрова А.Е. Новые педагогические и информационные технологии в системе образования. - М., 2007. - 256 с.

4. Чечель И.Д. Исследовательские проекты в практике школы. Управление исследовательской деятельностью педагога и учащегося в современной школе. - М.: Сентябрь, 2005. - С. 83-128.

5. Юркевич В.С. Одарённый ребёнок: иллюзии и реальность. Книга для учителей и родителей. - М.: Просвешение. 2006. - 97 с.

6. Российская государственная библиотека [Электронный peсурс] / Центр информ. технологий РГБ; ред. Т.В. Власенко; web-мастер Н.В. Козлова. - Электрон, дан. - М.: Рос. гос. б-ка. 1997. 


\section{РАЗВИТИЕ И СОВЕРШЕНСТВОВАНИЕ МЕТОДОВ ЕСТЕСТВЕННОНАУЧНОГО ОБРАЗОВАНИЯ МЛАДШИХ ШКОЛЬНИКОВ}

Е.В. Григорьева

Современный Федеральный государственный образовательный стандарт начального общего образования нацелен на развитие познавательной активности и творческой самостоятельности младших школьников. В связи с этим растет роль активных методов естественнонаучного образования детей.

В классической методике преподавания естествознания принята классификация методов обучения по источнику знаний. Методологическим основанием для того, чтобы выделить источник знаний в качестве главного классификационного признака, служит философское представление о сходстве объектов и методов их изучения в естественных науках и методике обучения естествознанию. Объектом изучения естествознания является природа. Основным источником получения знаний о ней являются непосредственные природные объекты и явления или их отображения. Субъектом обучения является учащийся, деятельность которого направлена на получение знаний о природе. Учитель, руководя процессом познания, помогает ученику выбрать наиболее рациональные способы для этого. Таким образом, выделяют словесные, наглядные и практические методы естественнонаучного образования младших школьников. Методы обучения в любом обществе изменяются в соответствии с целями образования. В древние времена обучение было основано на подражании. Дети получали определенные навыки, повторяя за взрослыми их действия.

Вместе с появлением первых школ возникли словесные методы преподавания. В их основе лежала передача учителем готовой информации с помощью письменного, устного, а позднее и печатного слова. Эти методы доминировали вплоть до XIX века. Словесные методы были основными в период становления методики преподавания естествознания. Со временем появились новые течения в педагогике, которые подвергли словесные методы справедливой критике. «В естествознании, задача которого дать сведения о предметах и явлениях природы, одно только словесно-книжное обучение не дает правильных представлений о природе и иссушает самый предмет, убивая у учащихся интерес к природе. 
Объясняя явления природы, преподаватель обязан показать эти предметы или явления в натуре или хотя бы на рисунках» [4].

В эпоху бурного развития промышленности и великих открытий на первый план выходят наглядные методы преподавания, помогающие связать слово с образом предмета. Эти методы отвечали естественным свойствам человека, черпающего знания из внешнего мира с помощью органов чувств. Наглядный (или предметный) метод обучения был основным требованием дидактики на протяжении всего XIX века. Его противопоставляли словесному (или вербальному).

Уже во второй половине XIX века обозначились первые попытки перейти от простых наблюдений к более полному ознакомлению детей с изучаемыми объектами природы путем проведения опытов. При этом к зрению подключалась деятельность и других анализаторов. В естествознании такая учебная деятельность получила название практических занятий. Так возник в методике преподавания новый принцип, который стали называть моторным или двигательным, т. к. он соединяет работу органов чувств и мышления с работой рук. Осуществляя этот принцип, преподаватель раздавал учебные пособия и оборудование в руки самих учащихся для самостоятельных опытов и наблюдений. Уроки, на которых проходила самостоятельная работа с предметами природы, А.Я. Герд назвал предметными.

К методам обучения естествознанию А.Я. Герд добавил и разработал методику проведения практических занятий на предметных уроках в классе, базовым материалом для которых служила местная природа. Его книга «Предметные уроки в начальной школе», появившаяся в 1883 году, включала десятки практических работ, которые могли проводиться в классе или дома. А.Я. Герд считал, что главная задача учителя - проводить на уроках грамотные объяснения, а дети, наблюдая природные объекты и проводя с ними опыты, будут учиться описывать, сравнивать, обобщать, делать соответствующие выводы. «Нет лучшего средства возбудить интерес и развить в детях наблюдательность и самостоятельность, как поставить их в положение маленьких исследователей», - писал А.Я. Герд [1].

Практические работы стали относить к практическим методам преподавания естествознания. А.Я. Герд сам разработал методическое руководство для учителей «Первые уроки минералогии». Планы уроков по изучению неживой природы явились первым образцом методики преподавания отдельного предмета.

Подробнее рассмотрим методику применения словесных, наглядных и практических методов обучения на современных уроках «Окружающий мир». 
К словесным методам относятся способы овладения новыми знаниями, источником которых служит устное или письменное слово.

«Поток информации - вот важнейшее условие полноценного умственного развития», - считал В.А. Сухомлинский. - То, что ребенок видит сам, - это еще не поток информации. Человеческое воспитание в том и заключается, что старшие передают детям готовые знания об окружающем мире, энергией своей мысли постоянно питают поток информации, воздействующий на ребенка» [9].

В начальной школе применяются следующие словесные методы: рассказ, беседа, учебная дискуссия и работа с книгой.

Рассказ - это последовательное повествовательное изложение учебного материала.

В дидактике термин «рассказ» относят не ко всем случаям повествовательного изложения материала, а только к тем, где идет речь о событиях, развертывающихся во времени. Это может быть повествование о биографиях ученых, о географических открытиях, об эволюционных процессах. Основными элементами этого рассказа являются завязка, кульминация и развязка. В повествовательном рассказе очень часто применяется так называемая образная или словесная наглядность.

Предварительно дети должны получить задания, помогающие воспринимать и анализировать получаемую информацию. Например: разделить рассказ на смысловые части и выделить их главную мысль. Озаглавить каждую часть. Составить план рассказа. Сформулировать проблему, которая раскрывается данным повествованием и т. п.

Приведем пример рассказа-повествования «Почему без воды нет жизни»:

«Вы знаете, что жизнь на Земле возникла только после того, как на планете появилась вода?

Попробуем представить, как выглядела Земля, перед тем, как на ней появилась жизнь.

Четыре с половиной миллиарда лет назад молодая Земля была безжизненным огненным шаром. Мрачная поверхность планеты содрогалась. Повсюду извергались вулканы, выплескивая облака пара и огненные реки лавы.

По мере охлаждения Земли водяные пары превращались в жидкую воду, которая выпадала на ее остывающую поверхность. Первобытное небо то и дело затмевали тучи, грохотали грозы, на окутанную туманом землю обрушивались ливни. Дожди шли тысячи лет. Так образовался первичный океан. 
Беспокойный синий океан занимал две трети поверхности планеты. Остальное - суша, один огромный материк, сплошной бурый камень, в котором блестели вкрапления цветных минералов.

Четыре миллиарда лет назад атмосфера Земли еще не содержала свободного кислорода. Не было ни растений, ни животных, ни бактерий.

На протяжении миллиарда лет после рождения планеты в ее атмосфере и водах накапливались вещества, из которых будут строиться живые организмы. И вот в теплом первобытном океане начала зарождаться настоящая жизнь. Она оставалась в океане более двух миллиардов лет, непрерывно изменяя свои формы. От простого и примитивного жизнь развилась до непостижимой сложности человека» [4].

По характеру изложения можно выделить и другие разновидности рассказа (по Н.А. Рыкову).

Описание деталей, явлений, расположенных в пространстве.

Вот пример описания растения горной тундры. «Ива в Уральских горах совсем не похожа на плакучую иву на берегу водоемов. Она растет не в высоту, а в ширину. Это ива арктическая. Ее ветки могут достигать пяти метров в длину, но они никогда не поднимаются выше, чем на 10 см от земли. Таким образом, ива защищается от ледяного ветра и прячется под снежным покрывалом в течение всей зимы. Листья арктической ивы мелкие, блестящие, почти округлые. Они испаряют мало воды. В суровых условиях влагу нужно экономить. Ведь из холодной почвы корни медленно поглощают воду. Арктическая ива имеет много полезных свойств. Она останавливает кровотечение, смягчает зубную боль. Кроме того, это растение содержит витамин С. Любят иву животные. Для птиц почки арктической ивы являются источником питания» [4].

Во время такого рассказа обязательно применение натуральных или изобразительных наглядных пособий. Ученики должны составить план описания природного объекта.

Объяснение - изложение учебного материала, связанного с ответами на вопросы «Как?», «Почему?». Под объяснением понимается словесное истолкование существенных свойств изучаемых объектов, закономерностей рассматриваемых явлений.

Во время объяснения учитель должен:

- четко формулировать проблему;

- использовать примеры, аргументирующие выдвинутые положения;

- устанавливать причинно-следственные связи; 
- применять приемы сравнения, сопоставления изучаемых объектов и явлений;

- логично излагать изучаемый материал;

Приведем пример объяснения роли воды в живых организмах.

«Вы когда-нибудь задумывались, почему в живых организмах так много воды? Так, например, тело взрослого человека на $70 \%$ состоит из воды, тело рыб содержит $80 \%$ воды, водорослей - $90 \%$. Вода является необходимым условием существования всех живых организмов на Земле. Подсчитано, что содержание воды в живых организмах примерно в шесть раз превышает ее количество во всех реках земного шара. В живом организме вода - это главный растворитель питательных веществ. Процессы пищеварения и усвоения пищи человеком и животными связаны с переводом питательных веществ в раствор. Вода, попадая в кровь, приносит в клетки кислород и питательные вещества, а также вымывает из клеток продукты обмена веществ. Вода играет важную роль в поддержании температуры тела. Исключение ее из организма может привести к смерти уже через несколько дней. Человеку нужно выпивать полтора-два литра воды в день» [4]. Объяснение часто выделяется как самостоятельный словесный метод преподавания.

Доказательство - утверждение, подкрепленное фактами. Ученики, слушая или читая такой рассказ, должны сформулировать проблему и привести доказательства приведенного утверждения. Примером может служить рассказ, доказывающий, что без насекомых невозможно существование жизни на Земле.

«Рассказывает известный энтомолог профессор Г.А. Мазохин-Поршняков: «Представим на минуту, что насекомые исчезли с лица Земли...и перед нашим мысленным взором пройдут мрачные картины изменений в природе. Поблекли краски лугов и полей, ибо вымерли все цветковые растения, кроме опыляемых ветром, птицами и летучими мышами. Не стало семян и плодов, а значит и растительноядных животных, которые ими питаются. Следом погибло большинство насекомоядных и хищников. Резко упало плодородие почв - ведь бесчисленные насекомые разрыхляли, перемешивали и удобряли почву. Без насекомых-санитаров, потребляющих и обычно закапывающих животные останки, воздух наполнился смрадом разлагающихся трупов и экскрементов. Леса, степи, поля оказались под ворохом опавших листьев и погибших растений. Без насекомых грибы и микробы не справились с переработкой отмерших растений» [6]. Ко всем вышеназванным разновидностям рассказа обычно предъявляются сходные дидактические требования. 
Любой рассказ имеет четкую, определенную структуру, доступную для данного возраста детей. Продолжительность рассказа в первом-втором классах - 1-3 минуты; в третьем-четвертом классах $-4-5$ минут.

Методические требования к рассказу:

- научность, доступность, логичность;

- постановка познавательных задач, нацеливающих детей на восприятие нового материала;

- использование образных примеров, демонстрация наглядных пособий;

- стилистически грамотное изложение, без искажения слов и их неправильного употребления, отсутствие фактических ошибок;

- выделение главного и формулировка основных понятий;

- установление значимых для данной возрастной категории учащихся связей с жизнью.

Одна из целей применения словесных методов обучения - оптимальная активизация познавательной деятельности младших школьников путем использования рассказов поискового характера, усиления их эмоциональной выразительности. Учитель должен помнить, что мышление детей связано с их эмоциональной сферой. В изложении материала желательна подлинная эмоциональность [2].

Рассказ как метод активного обучения должен решать следующие учебные задачи:

1. Учить детей анализировать.

Например, перед рассказом о растениях тундры детям раздаются гербарии, и учитель просит их подумать над вопросом: «Какие особенности строения растений можно выделить?».

2. Учить сравнивать.

Например, можно попросить детей подумать над вопросом: «Смогла бы ива (верба), растущая на берегу нашей реки, жить в тундре?». Для ответа на этот вопрос учащимся нужно будет сравнить внешнее строение полярной ивы и вербы, климатические условия, в которых они растут, и сделать соответствующие выводы.

3. Выделять главные, существенные признаки.

Например, перед тем, как рассказать о тушканчике, учитель вывешивает его изображение и ставит познавательную задачу: «Выделите основные черты приспособленности животного к жизни в степи».

4. Учить составлять план рассказа и действовать по плану.

Например, учитель может спросить детей, по каким пунктам плана строился рассказ о тушканчике и выписать план на доску. Перед рассказом о другом животном дается задание: «Прослушайте рассказ и сделайте вывод, все ли пункты плана были раскрыты в рассказе». 
1. Учить задавать вопросы.

Перед рассказом учитель просит каждого ребенка придумать вопрос к рассказу. После рассказа вопросы детей выслушиваются и анализируются.

Нужно отметить, что в чистом виде рассказ в начальной школе применяется довольно редко. Обычно он сопровождается элементами беседы.

По дидактическим целям выделяют:

1. Вводную (вступительную) беседу. На ней актуализируются опорные знания, необходимые для изучения новой темы. Например, при изучении значения почвы в круговороте веществ детей просят вспомнить: «Как образуется почва?», «Какие компоненты входят в состав перегноя?», «Какую роль в почве играют бактерии?», «Какое значение имеет почва в жизни растений?», «Какова роль растений в жизни животных?» Без этих знаний учашиеся не смогут в дальнейшем построить схему круговорота веществ.

2. Беседу - открытие новых знаний. Во время нее вопросы учителя должны подводить детей к маленьким «открытиям». Например, при изучении любой природной зоны учитель беседует с детьми по вопросам, позволяющим им самим сделать вывод о погодных условиях, почвах, растительном и животном мире в данной природной зоне. При изучении степной зоны можно задать следующие вопросы: «Как расположена зона степей по сравнению с зоной лесов?», «Как будут прогревать территорию степей солнечные лучи?», «Де, по-вашему, будет более жаркое и продолжительное лето: в зоне лесов или степей? Почему?», «Сравните изображения леса и степи. Какие характерные особенности природы степи вы заметили?», «Почему в степи преобладают травянистые растения?», «Могут ли в степи постоянно обитать крупные животные? Почему?» и т. д.

3. Обобщающую беседу. На ней систематизируются знания детей, устанавливаются причинно-следственные связи между новыми и уже сформированными представлениями и понятиями. К такой беседе должна быть подготовлена строго продуманная система вопросов и предполагаемых ответов детей. Следует заранее подготовить вспомогательные и корректирующие вопросы. Они должны быть не только репродуктивными, но и в большей степени носить творческий характер, требовать применения полученных знаний в новых ситуациях. Можно предложить следующие продуктивные вопросы:

- поставленные в новой редакции, по возможности, в виде небольших задач. Например: «Протяженность реки Миасс в пределах Челябинской области на 110 км больше, чем за ее пределами. Длина реки Теча составляет 243 км, это на 415 км меньше длины Миасса. Чему равна длина реки Миасс в пределах нашей области?»; 
требующие связного ответа-рассказа. Например: «Объясните, почему в березовом лесу много травянистых растений»;

- вопросы на сравнение природных объектов и явлений. Например: «Могут ли поменяться лесными «этажами» дятел и орел? Объясните свой ответ»;

- требующие установления причинно-следственных связей. Например: «С какими явлениями в неживой природе связано начало сокодвижения у растений?»;

- обобщающие наблюдения учащихся. Например: «На основании своих наблюдений за весенними изменениями в природе объясните, как влияет повышение температуры воздуха на характер осадков, состояние водоемов и почвы?»;

- практического характера. Например: «Как вы поступите, если увидите, что семья моет свой автомобиль на берегу озера?»;

- требующие приведения примеров: «Как люди могут разрушать плодородие почвы?».

Беседа дает необходимый педагогический эффект, если вопросы к ней будут грамотно сформулированы.

Как можно реже следует задавать вопросы:

- в неопределенной форме. Например: «Что вы можете сказать о растениях леса?»;

- заключающие в себе уже готовый ответ. Например: «Гранит - это полезное ископаемое?»;

- требуюшие односложных ответов «да» или «нет». Например: «Можно ли оставлять мусор в лесу?»;

- двойные или тройные. Например: «Какие растения и животные обитают в степи?».

Вопрос вначале задается всему классу, дается время на обдумывание, а затем вызывается один ученик. Остальные дети дополняют ответ. Учитель обобщает ответы учащихся.

Грамотное применение беседы на уроках, устраняет пассивное восприятие излагаемого учителем материала, повышает активность класса.

Словесные методы обучения естествознанию играют важную роль в развитии речи младших школьников. Учитель должен обращать особое внимание на культуру речи учащихся, исправлять неграмотную формулировку ответов, учить детей рассуждать, делать выводы. В.В. Половцов подчеркивал, как важно приучать детей к связному изложению своих мыслей: «Одной из больших бед нашей школы является ...игнорирование умения хорошо и ясно излагать свои мысли в устной речи. Поэтому рядом с краткими ответами на вопросы необходимо вести и более продолжительные устные отчеты» [7]. 
Постепенно ученики начальной школы должны научиться выступать с краткими сообщениями на заданную тему, участвовать в учебных дискуссиях.

Наглядные методы обучения естествознанию - это способы овладения учебным материалом, при котором новые знания дети получают в процессе моделирования природных объектов и процессов, при восприятии наглядных, экранных пособий и демонстрационных опытов.

На уроках «Окружающий мир» невозможно обойтись без демонстрации опытов и их результатов. Учитель показывает такие опыты с природными объектами, которые дети не могут провести сами ввиду их сложности или опасности. Это опыты, связанные с нагреванием или требующие использования химических реактивов. При подготовке демонстрационного опыта учитель должен выполнить следующие действия: проверить наличие оборудования и его техническое состояние; определить количество и качество веществ, которые будут использованы в опыте; провести опыт заранее, чтобы устранить неполадки и определить его продолжительность; составить вопросы, задания и комментарии к просмотру опыта учащимися.

Во время проведения демонстрационного опыта необходимо соблюдать следующие условия:

1) оборудование собирается на глазах у детей. При этом учитель дает название и объясняет назначение каждого прибора;

2) оборудование располагается так, чтобы опыт был виден всему классу;

3) перед проведением опыта учитель ставит познавательную задачу;

4) необходимо строго соблюдать правила техники безопасности;

5) во время демонстрации опыта учитель комментирует свои действия. Учащимся задаются вопросы: «Что вы наблюдаете? Почему это происходит? Какое свойство природного тела (или явление) было установлено в результате опыта?»;

6) после проведения опыта анализируются полученные результаты, делаются обобщения и выводы. Проводится беседа по вопросам: «Какое свойство природного тела (или явление) изучалось посредством опыта?», «Какое оборудование использовалось? Какое назначение имеет каждый (назвать конкретно) прибор?», «Как протекало явление? Почему?», «Когда и где можно наблюдать такое явление в природе или в жизни?».

Для закрепления полученных наглядным методом представлений демонстрационный опыт схематично зарисовывается в тетрадь [2].

Остановимся подробнее и на методике применения метода моделирования.

Моделирование в широком смысле слова - это замена действий с реальными предметами действиями с их образцами, моделями, муляжами, 
макетами, а также с их графическими заменителями: рисунками, чертежами, схемами и т. п. При этом рисунки могут изображать реальные предметы (людей, животных растения и т. п.) или же быть условными, схематичными, т. е. изображать реальные предметы условно в виде различных геометрических фигур.

Согласно теории поэтапного формирования умственных действий (П.Я. Гальперин, Н.Ф. Талызина и др.), будущее умственное действие начинает формироваться во внешнем плане в виде материального действия с реальными объектами, а потом с их заместителями. Затем действие переходит в план речи - сначала громкой, затем - шепотом и про себя. Организация этих этапов особенно необходима при обучении младших школьников.

Важно организовать обучение так, чтобы ребенок сам становился субъектом учебной деятельности. При этом не следует заменять задания, в соответствии с которыми учащиеся должны действовать на партах собственными руками, заданиями, в которых они только наблюдают деятельность учителя у доски. Также опасно слишком рано прекращать проговаривание вслух.

Введение в процесс обучения средств моделирования позволяют развивать у младших школьников способность к обобщению, переводя процесс их мышления на более высокий уровень. Обучая ребенка способу построения модели природных закономерностей, учитель осуществляет формирование в сознании учащихся соответствующих абстракций, подводит его к обобщению. Модели позволяют создавать у учащихся наглядные образы природных процессов и явлений, которые средствами предметной наглядности создать невозможно. Например, этот метод помогает сформировать представление об экологических связях в природе. Модели делают «видимыми» невидимые связи и служат опорой для запоминания и воспроизведения знаний о них. Процесс моделирования вместе с тем предполагает решающую роль самостоятельной работы учащихся в конструировании моделей.

Учителю важно тщательно подготовится к работе по моделированию.

1. Сделать сами модели. Они могут быть объемными (например, из пластилина) или плоскостными (из бумаги). При моделировании цепей питания, например, используются изображения растений и животных, выполненные на плотной бумаге или картоне и цветные стрелки. Можно заменить рисунки названиями объектов. От динамических моделей переходят к меловым схемам, которые учитель или ученик выполняют на доске.

2. Спланировать, на каких этапах урока будет использоваться метод моделирования и определить степень самостоятельности учащихся при 
работе с моделями. Дети могут наблюдать процесс моделирования, выполняемый учителем на магнитной доске (например, при изучении питания и дыхания растений). Затем учиться читать схему. Возможен вариант, при котором дети будут составлять модели на партах самостоятельно во время индивидуальной или групповой работы на закреплении изученного материала или актуализации знаний.

3. Выяснить, как процесс моделирования будет сочетаться с другими методами и приемами обучения.

Метод моделирования должен играть важную роль в начальном естественнонаучном образовании. Часто моделирование, выполняемое самими учащимися, относят к практическим методам обучения [2].

К практическим методам в современной методике естествознания относятся наблюдения, практические работы, исследовательский эксперимент.

Познакомимся подробнее с методикой проведения практических работ и исследовательского эксперимента.

Практические работы проводятся на предметных уроках «Окружающий мир». На них учащиеся делают маленькие открытия, опытным путем получая сведения о свойствах природных объектов и сущности явлений. Деятельность учителя и учащихся при этом проходит ряд этапов. В начале работы ставится познавательная задача (цель работы) и проводится инструктаж по ее выполнению.

Инструкции к практической работе должны быть ясными, четкими, конкретными. Если их нет в учебнике или рабочей тетради, то учитель сам составляет инструктивные карточки. Затем ученики в парах или группах проводят наблюдения и опыты по предложенным заданиям. Самостоятельность детей при выполнении заданий развивается постепенно. Первые работы разбиваются на мелкие рабочие операции и выполняются под команду учителя, который проделывает опыты одновременно с детьми. Этот методический прием синхронизирует работу класса. Когда ученики получат первоначальные умения проведения опытов, они могут работать самостоятельно, предварительно прочитав вслух инструкции в учебнике. Учитель руководит работой детей.

В последнем классе начальной школы работы выполняются частично самостоятельно. Ход работы намечается коллективно, затем дети проводят опыты самостоятельно. Обсуждение результатов практических работ проходит коллективно.

На следующем этапе проводится фиксация результатов работы в таблице, схеме или на рисунке. Фиксация результатов проделанных опытов может проводиться в процессе работы или по ее окончании. 
В последнем случае учащиеся воспроизводят результаты по памяти, закрепляя полученные знания.

По окончании самостоятельной работы проводится ее описание учащимися. Делаются обобщения и выводы, решающие познавательную задачу.

Приведем пример практической работы по теме «Гранит».

Перед учащимися ставится познавательная задача исследовать свойства гранита и минералов, из которых он состоит. Практическая работа выполняется по следующим заданиям:

1. Название гранита произошло от латинского слова «гранум» «зерно». Внимательно рассмотрите образец гранита. Как вы думаете, почему гранит получил такое название?

2. Зерна какого цвета входят в состав гранита? Гранит состоит из трех минералов. Зерна красного (розового) или серого цвета - полевой шпат. Именно он определяет цвет гранита. Белые или дымчато-серые зерна кварц. Черные вкрапления - слюда.

3. Рассмотрите полевой шпат, кварц и слюду по отдельности из своих коллекций. Запишите цвет каждого из них в таблицу.

4. Блеск - способность минерала отражать свет. Определите, есть ли блеск у составных частей гранита. Какой это блеск?

5. Определите твердость полевого шпата, кварца и слюды. Если минерал оставляет царапину на стекле, значит он твердый. Если царапины на стекле не остается, то проведите по минералу ногтем. Если ноготь оставил царапину, то минерал мягкий, если нет, то средней твердости.

6. Где применяется гранит? Какие памятники и постройки из гранита вы встречали в своем населенном пункте? [3].

Результаты записываются в таблицу.

\begin{tabular}{|l|l|l|l|}
\hline \multicolumn{1}{|c|}{ Свойства } & \multicolumn{1}{|c|}{ Кварц } & \multicolumn{1}{c|}{ Полевой шпат } & \multicolumn{1}{c|}{ Слюда } \\
\hline Цвет & Белый, дымчато-серый & Розовый, серый & Черный, бесцветный \\
\hline Блеск & $\begin{array}{l}\text { Неметаллический, } \\
\text { стеклянно-жирный }\end{array}$ & $\begin{array}{l}\text { Неметаллический, } \\
\text { стеклянный }\end{array}$ & $\begin{array}{l}\text { Неметаллический, } \\
\text { перламутровый }\end{array}$ \\
\hline Твердость & Твердый & Твердый & Мягкий \\
\hline
\end{tabular}

Результаты практических работ могут фиксироваться и в схеме. Примером может служить работа по изучению состава и свойств почвы. Перед началом работы ставится проблемный вопрос: «К живой или неживой природе можно отнести почву?» Дети исследуют состав почвы по инструкциям учебника, наблюдают за демонстрацией опытов учителем, читают текст «Что растения берут из почвы» и заполняют схему: 


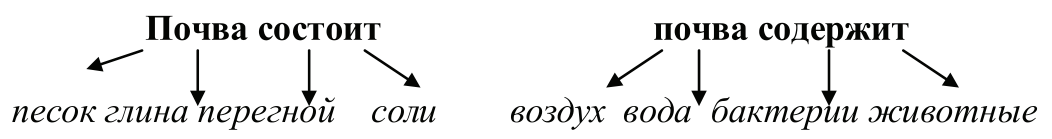

После окончания работы делается вывод: почву нельзя отнести только к неживой или только к живой природе. Учитель сообщает, что почву можно рассматривать как промежуточное звено между неживой и живой природой.

Иногда результаты практической работы оформляются в виде рисунка. Примером могут служить работы «Части цветкового растения», «Этапы развития растения из семени».

Практические работы выделены в каждой естественнонаучной программе для начальной школы и обязательны для проведения. На практических работах развиваются умения детей, необходимые для изучения естественных наук в основной школе. К выполнению работ учащихся нужно приучать систематически, постепенно переходя от коротких и несложных по организации к более продолжительным и сложным [2].

К долговременным и сложным по организации относится исследовательский эксперимент. В начальной школе он применяется как метод обучения, чаще всего, во внеурочной деятельности.

Проведение эксперимента требует тщательной подготовки. При этом учитель должен соблюдать ряд правил:

1. В экспериментальном исследовании важную роль играет предварительная гипотеза, т. е. предположение, выдвигаемое для объяснения тех явлений, которые предполагается изучать посредством эксперимента.

2. Для проведения исследования необходимо иметь контрольный и экспериментальный экземпляры исследуемых объектов.

3. Важным отличием эксперимента от обычного наблюдения является вариация условий наблюдения. В природе на один объект воздействует широкий спектр условий. В экспериментальном опыте по возможности устраняются те явления, которые маскируют изучаемый процесс и вводятся факторы его усиливающие.

4. При постановке эксперимента необходимо руководствоваться методом единственного различия условий проведения контрольного и экспериментального опытов.

Например, мы хотим исследовать влияние прекращения полива на рост листьев лука репчатого. При этом контрольные и экспериментальные экземпляры лука должны находиться в условиях одинаковой освещенности и температуры. Варьировать должен только один 
фактор - полив. Контрольные экземпляры поливают сразу при подсыхании верхнего слоя почвы, а у экспериментальных полив прекращают. В ходе исследовательского эксперимента проводятся ежедневные наблюдения за контрольными и экспериментальными экземплярами. Фиксация результатов ведется только в те дни, когда наступают заметные изменения. Опыт считается законченным, когда получены веские доказательства роли исследуемого фактора: появляются хорошо заметные различия опытных и контрольных экземпляров. В данном опыте заведомо предполагалось, что без полива рост лука постепенно прекращается, поэтому не следует ждать, когда изменения станут необратимыми и растения погибнут. После подтверждения гипотезы полив контрольных экземпляров нужно возобновить.

При подведении итогов эксперимента важна не только констатация наблюдаемых различий, но и их научное объяснение. Выводы используются в дальнейшем обучении естествознанию [2].

Наиболее широкое поле деятельности для исследовательской работы предоставляет школьный учебно-опытный участок. На пришкольном участке проводится опытническая работа, на основе которой у детей формируются исследовательские умения.

Учебно-опытный участок для начальной школы выделяется как самостоятельный отдел. По возможности он должен быть расположен на ровной поверхности, хорошо освещен и защищен от господствующих ветров зданием школы или живой изгородью. Площадь участка зависит, прежде всего, от количества учащихся. В общей сложности земельная площадь, обрабатываемая вручную одним учеником, не должна превышать 2-4 кв. м.

На участке начальных классов оформляются овощной, плодовоягодный, декоративный и коллекционный отделы. В городской школе самую большую площадь занимает цветник и декоративные деревья и кустарники, а в сельской - овощной отдел.

Сельскохозяйственный труд детей, как и практическая работа на уроке начинается с постановки целей и определения плана работы. После выполнения намеченного плана подводятся итоги и фиксируются результаты работы. Физический труд и натуралистические исследования должны сопровождаться фенологическими наблюдениями.

По мнению М.Н. Скаткина, эффективность опытно-натуралистической работы зависит от умения учителя сочетать физический труд детей с умственным, «соединять работу рук учащихся с работой головы» [2]. 


\section{Библиографический список:}

1. Герд А.Я. Предметные уроки в начальной школе. - СПб.: Изд. Л.Ф. Пантелеева,1914. - С. 14.

2. Григорьева Е.В. Методика преподавания естествознания» учеб. пос. для студентов вузов, обучающихся по специальности «Педагогика и методика начального образования» / Е.В. Григорьева. - М.: ГИЦ ВЛАДОС, 2008.

3. Григорьева, Е.В. Природа Южного Урала: учебное пособие - приложение к учеб. «Окружающий мир» для уч-ся 3-4 кл / Е.В.Григорьева. Челябинск: АБРИС, 2014.

4. Григорьева, Е.В. Книга для чтения по краеведению. 2-4 классы: хрестоматия / Е.В.Григорьева. - Челябинск: «Край Ра», 2011. - С. 28-29.

5. Григорьева Е.В. Интеллектуальный краеведческий марафон: сборник заданий для младших школьников / Е.В. Григорьева, М.М. Бормотова и др.: под общей редакцией Н.П. Шитяковой. - Челябинск: АБРИС, 2014. - C.24.

6. Козлов М.А. Не просто букашки. - 2-е изд. / М.А Козлов. - СПб.: Гидрометеоиздат, 1994. - С. 41.

7. Половцов В.В. Общая методика естествознания / В.В. Половцов. - М., 1907. - С. 261.

8. Райков Б.Е. Общая методика естествознания. - М. - Л.: Учпедгиз, 1947. - С. 137.

9. Сухомлинский В.А. Сердце отдаю детям. - Минск, 1981. - С. 11. 


\section{РЕШАТЬ НЕСТАНДАРТНЫЕ ЗАДАЧИ: КАК ЭТОМУ НАУЧИТЬ}

В.В. Дрозина

Одной из важнейших задач для современной России является сохранение и укрепление конкурентоспособного кадрового капитала государства. Национальный проект в образовании нацелен на воспитание нового человека, которому по плечу качественное развитие страны. Таким человеком является творческая личность, а в основу инновационного педагогического процесса заложено воспитание творчества у учащихся.

На Первом Всесоюзном симпозиуме психологов, был сделан вывод о том, что творчество не является уделом избранных, и что творческие способности можно развивать.

Исследования психологии человека $[1,4,11]$ показывают, что каждый индивидуум имеет определенные задатки, способствующие развитию способности в той или иной жизненной области. Поэтому воспитание творчества, должно охватывать не только одаренных детей, способных участвовать в олимпиадах, но и всех остальных, у которых одаренность находится вне предметных занятий. Учить их творчеству в системе - это процветание России в будущем.

Творчество позволяет усилить человеческий потенциал решения нестандартных задач. Рассматривая понятие «нестандартная задача», следует отметить его обобщенность и наивысшую значимость внутреннего содержания в отношении других понятий «задача»:

1. Задачей называют поставленную цель, которую стремятся достигнуть (в широком смысле слова).

2. Задачей называют вопрос, требующий решения на основании определенных знаний и размышления (например, математическая задача).

3. Олимпиадная задача - это определенное задание, из какой-либо области знаний данное для соревнования учащимся на лучшее его выполнение.

4. Нестандартная задача заключает в себе нечто оригинальное, творческое. Это понятие охватывает все качества, присущие другим понятиям в отношении «задача», преломленные через творчество.

К основным компонентам аппарата творчества индивида, как показали исследования $[6,7,8]$, могут быть отнесены компоненты, которые условно разделяются на два блока.

Первый блок состоит из сопутствующих ингредиентов, целенаправленно не изменяющихся на данный момент (индивидуальные психологические 
свойства личности и пр.). Они активно влияют на компоненты второго блока, сами, находясь в относительном покое. Второй блок - это компоненты, которые постоянно качественно изменяются от целенаправленного воздействия на них. К ним относятся научные знания, вид творчества, творческое мышление, умения творческой работы, которые, в свою очередь, оказывают содействие созданию системы основных качеств, присущих творческому человеку.

Превалирующее место в творчестве занимают такие качества как анализ, синтез, предвидение, однако в преломлении творчества они имеют особенные черты [7], которые, охватывают основные присущие этим понятиям признаки, преломленные через особенности творческой самостоятельности.

При формировании этих качеств учитывается возраст младшего школьника (6-7 - 8-12 лет). Ученые Г.С. Абрамова [1], Л.С. Выготский [4], П.П. Блонский [3] отмечают, что семилетний возраст является кризисным, а 8-12 лет - стабильным. Каждый из этих возрастов характеризуется своими чертами, которые по своему влияют на воспитание творчества.

Л.С. Выготский [4] ставит акцент на негативном содержании кризисного периода. Который, как он отмечает, проявляется в нарушении психического равновесия, неустойчивости воли и настроения. Кризисный период характерен резкими сдвигами, смещениями, изменениями и переломами в личности ребенка, который в короткий срок меняется в целом. Развитие ребенка носит бурный, стремительный, иногда катастрофический характер. Этот период продолжается в течении небольшого времени - несколько месяцев, год или, самое большее, два.

Стабильный возраст (8-12 лет) с одной стороны можно охарактеризовать, как остроту и свежесть восприятия, любознательность, яркость воображения и пр. С другой стороны, как личностные проявления выражающиеся в важности установления и осуществления социальных связей и т. п. Возникающее противоречие в этом возрасте состоит в готовности отвечать на воздействия других, и в то же время, сочетается с необходимостью защищать границы своего психологического пространства, чтобы сохранять свое Я. Разрешая данное противоречие, ребенок овладевает качеством трудолюбия через воплощение. Как видно, становление творчества у детей этого возраста носит свою характерную особенность.

Особенность обучения младших школьников разных возрастов должна быть четко учтена. Если в кризисном возрасте акцент при формировании умения ассоциативной (от лат. - соединение, связь) работы ставится на изучении различных направлений, в которых происходит ассоциирование, то в стабильном возрасте главное - это отработка 
процесса данного умения и продолжение шлифовки направлений ассоциации. При формировании и развитии умения соединять компоненты знаний в кризисном возрасте подразумевается отработка таких направлений как: сущность явления, характеристика явления, сравнение, взаимосвязь одного явления с другим. В стабильном возрасте продолжается работа над формированием и развитием умения соединять компоненты знаний. Она ведется в двух направлениях: во-первых, продолжают закрепляться умения с ранее рассмотренными аспектами, во-вторых, вводятся новые и проводится работа с ними.

Рассмотрим более подробно формирования такого качества, как синтез.

Синтез является уникальным объектом, который составляет основу всех аспектов любой деятельности и определяет ее итог.

Исследуя физиологию процесса синтеза, В.М. Бехтерев [2], С.О. Грузенберг [5], И.П. Калошина [10], А.Н. Лук [11] напрямую связывают ее с творчеством. Синтез трактуется, как созидательный процесс, результатом которого является новое образование. Для становления экстраполяции стиля деятельности (основа в творчестве), предполагающей получение выводов на одной части явления и созидательное распространение их на другую, необходимо овладеть операцией синтеза.

Для творческой деятельности выделен синтез, которому свойственны особенности, присущие творчеству. Любые психологические процессы, участвующие в творчестве, содержат синтез, будь то творческие способности, творческое мышление, воображение и т. п.

Тот вид синтеза, который непосредственно принимает участие в творчестве, получил название синоптического [7]. Он устанавливает конечный результат процесса и является одним из основополагающих компонентов, который способствует приобретению субъектом потребности в творчестве.

Синоптический синтез, во-первых, позволяет отслеживать все составляющие творчества: психологические факторы, которые определяют природу творчества; характер входа в творческий процесс; структуры творческого процесса; конечный результат творчества. Во-вторых, способствует становлению качеств, присущих творческой личности, таких, как: высокий интеллект, предполагающий владение операцией синтеза; оперирование с нечетко определенными понятиями, которое указывает на умение пользоваться операциями анализа и синтеза; обладание активностью отражения, которое является условием развития психики; готовность к риску.

Функции синоптического синтеза разносторонние:

- объединяюще-интегративная (объединение части в одно целое);

- инструментальная (средства, применяемые для достижения цели); 
- алгоритмическая (совокупность сведений о ходе действий);

- стратегическая (объединение содержания основных установок, важных в становлении ряда особенностей творческой личности);

- создания совокупности условий, которые способствуют развитию психики творческой личности;

- сущностная (совокупность внутреннего содержания);

- структурная (совокупность устойчивых связей объекта);

- активизирующая побуждение к действию творческого характера.

Критерии оценивания синоптического синтеза (проверяется результат, либо процесс) следующие:

- смотрится оригинальность;

- быстрота;

- объемная величина материала;

- трудность;

- функции синоптического синтеза.

При обучении синоптическому синтезу предполагается задействовать такие аспекты, с которыми он связан - это ассоциирование (объединение), эрудиция, умение соединять компоненты знаний, отдаленность ассоциируемых понятий, смысловое расстояние. Методика его развитие, исходя из возрастных особенностей младших школьников, подробно описана в книге В.В. Дрозиной, В.Л. Дильман, Д.А. Дрозин [8,9].

Универсальным средством, способствующим формированию и развитию синоптического синтеза, является директориальная синтезированная игра, поскольку она может играть роль формы, метода, приема обучения.

Директориальная синтезированная игра - это ряд действий, планомерных, продуманных, вызывающих интерес, приносящих удовольствие и направленных на формирование синоптического синтеза.

Функции директориально синтезированной игры следуюшие:

1) психолого-материализующая функция, которая предполагает подготовку физиологического состояния учащихся для творческой деятельности, а также нацелена на перестройку психики для развития творческой самостоятельности;

2) функция возбуждения интереса. В процессе игры создается атмосфера, когда урок превращается в увлекательное мероприятие, появляется азарт, происходит разрешение возникающего в этом возрасте противоречия - «новое видение своего места в обществе и несоответствие его реальному положению», т. е. происходит самоутверждение;

3) функция раскованности, которая несет с собой свободное внутреннее состояние, снятие закомплексованности; 
4) функция возмещения эмоциональной перегрузки нервной системы в ходе занятий;

5) развивающая функция. В процессе директориальной синтезированной игры происходит:

- развитие психологических новообразований (памяти, внимания, воображения, символической функции сознания);

- развитие черт характера творческой самостоятельной личности (решительности, оперативности, инициативности, активности и др.);

6) функция включения всех стилей обучения, которая предполагает, что учащиеся могут получать информацию по всем каналам восприятия, в том числе, и по соответствующему каналу его модальности.

Перечень основных черт.

Действия участников происходят в нестандартных ситуациях. Следует отметить, что решения проблем неизвестны, хотя условия заданы. В ходе директориальной синтезированной игры в полной мере используются возможности каждого учащегося. Она ориентирована на максимальную интенсивность. Ее можно охарактеризовать следующим образом:

1) назначение: системный метод формирования и развития синоптического синтеза;

2) основной механизм: индивидуальное, групповое соревнование способов нахождения неординарного решения;

3) основной принцип: творческая разработка и органическое соединение психолого-педагогических особенностей учащихся и формы урока;

4) структура: количество играющих 25-30 человек; в группах 4-5 человек; ведущий (создающий ситуацию);

5) главный итог: развитие и формирование синоптического синтеза. А по большому счету является сформированность определенного уровня творческой самостоятельности.

Подготовка директориальной синтезированной игры.

Принимают активное участие преподаватель и учащийся. Схема подготовки заключается:

1) в деятельности преподавателя, который, во-первых, использует текущую тему (объём учебного материала). Во-вторых, определяет вид игры, состав - индивидуальный, групповой, конечные результаты. B-третьих, разрабатывает и составляет игры:

- правило игры;

- сценарий игры;

- время игры;

- режим работы;

- задания;

- критерии; 
2) в деятельности учащихся, повторяющих основные положения темы, изучающих дополнительную литературу.

Принципы.

Регулирующую и направляющую роль в теории директориальной синтезированной игры, исполняют дидактические принципы, на основе которых построен как сюжет, так и ее содержание.

К дидактическим принципам построения директориальной синтезированной игры, относятся:

- целенаправленность;

- учет возрастных и индивидуальных особенностей учащихся;

- выбор оптимальных игровых форм, средств;

- работа над развитием и формированием синоптического синтеза у всех учашихся.

К дидактическим принципам построения смысловой части директориальной синтезированной игры, отнесем:

- системность. Целостная система (творческая самостоятельная деятельность учащихся, взаимодействие учащихся, учащихся и учителя);

- активность. Развитие и формирование синоптического синтеза у учащихся (самых слабых, средних, самых сильных);

- единоначалие. Руководитель игры направляет ход событий в течение всего игрового периода;

- самостоятельное творчество. В ходе игры: в начале - отдельные учащиеся (консультанты, ведущий), в конце - все играющие. Возникают новые ситуации, идеи, постановка задач, новые методы, формы, решения.

Частной характеристикой директориальной синтезированной игры являются особенности соответствующие строению синоптического синтеза (его структуре, энергии, функциям и т. п.). Это выражено в том, что:

1) директориальная синтезированная игра устремлена на развитие и формирование синоптического синтеза;

2) ее цель - сформировать у учащихся побуждение к творческой деятельности;

3) она направлена на отработку связей синоптического синтеза: развитие их подвижности, оригинальности составления и т. п.;

4) акцент делается на совокупности материала необходимого для изучения какого-либо предмета, явления и т. п. и всех сведений полученных ранее о нем.

Директориальная синтезированная игра направлена:

1) на системное содержание развития связей: от линейных до многомерных; 
2) на воспроизведение структуры и функциональных компонентов модели синоптического синтеза;

3) на приближение к жизненным ситуациям, что непосредственно влияет на приобретение знаний о многих предметах и развитии связей между ними;

4) на переход от направляющей и руководящей деятельности преподавателя к самостоятельной творческой деятельности самих учащихся, что непосредственно влияет на такой компонент синоптического синтеза как трудность;

5) на универсальность, выступая в качестве деятельности, метода, приема, формы.

Рассмотрим формирование и развитие синоптического синтеза на математическом материале, хотя всецело сюда подходят и все другие изучаемые предметы. Следует отметить, что математика, как предмет, весьма сильно воздействует на развитие синоптического синтеза, который характеризуется рядом признаков: оригинальностью полученного результата, рациональностью, быстротой решения (способность быстро переходить из одной категории в другую), богатством привлеченного материала и т. д.

Основными целями курса математики в свете формирования и развития синоптического синтеза являются:

- обеспечение математической грамотности учащихся (чем шире научные знания, тем больше возможности развития связей между ними);

- формирование и развитие умения применять эти знания творчески самостоятельно на практике (т. е. активизация на творчество);

- продолжение математического развития, включающего в себя творческое мышление (открытость опыту, широту категоризации, беглость мышления гибкость мышления оригинальность) - энергию синоптического синтеза; умения творческой самостоятельной работы (умения наблюдать и сравнивать, проводить обобщения и т. п.); развитие математической памяти и речи.

В соответствии с этими целями ставятся следующие задачи:

- повысить уровень освоения математики;

- усилить взаимосвязь между математикой и другими предметами, а также аспектами социума;

- совершенствовать методы, средства, формы руководства творческой самостоятельной работой учащихся;

- создавать учебные пособия для учащихся, которые помогут им целенаправленно организовывать творческую самостоятельную деятельность;

- на занятиях применять целенаправленные оптимальные средства. 
Рассмотрим ряд основных способов, которые используются в директориальной синтезированной игре.

Постановка цели занятия перед учащимися. Недостаточно назвать только тему данного занятия. Необходимо поставить перед классом конкретную цель, как бы ограничить рамками, конкретизировать, деятельность учащихся на данном отрезке времени. Например: «Сегодня наша цель -

1) освоить признак делимости на 2;

2) освоить свойство четности».

Это способствует возникновению, во-первых, стимулов творческой самостоятельной работы (стимулы к немедленному действию; стимулы, характеризующие готовность к действию и др.), во-вторых, включаются в работу индивидуальные психологические свойства личности, в-третьих, возникает интерес, а соответственно происходит изменение отношения учеников к работе на данном занятии.

Экспресс-анализ. Работа рассчитана на 5-7 мин в начале урока. Ее цель заключается в проверке и ориентации учеников на те теоретические знания, которые отрабатываются на данном занятии. Преподаватель разрешает учащимся повторить домашний материал в течение 3-4 мин, затем закрываются учебники и тетради. Ученики достают и подписывают листок, ставят номер варианта. Преподаватель диктует вопросы каждого варианта (повторяется дважды) и ученики работают в течение заранее оговоренного времени. Попрошествие отведенного времени работы собираются по вариантам. У учеников, получивших замечания в ходе работы листы не принимаются. Такой вид работы, во-первых, создает почву для полноценного усвоения практической части материала, во-вторых, является базой для дальнейшего усвоения как теоретического, так и практического материала. Все это ведет к приобретению полноценных знаний, развитию творческого мышления (беглость мышления, гибкость мышления и т. п.), формированию и развитию умений творческой самостоятельной работы (умение входить в активную умственную работу; умение представлять план предстоящих действий и т. п.).

Групповая работа на занятиях через активную познавательную деятельность учащихся обеспечивает активизацию энергии синоптического синтеза, а в конечном счете накопление опыта творческой самостоятельной деятельности. Учебная группа раз- 
деляется на 4-5 подгрупп (не более 5 человек в подгруппе). Даются 4-5 заданий (в зависимости от количества подгрупп) и время на их выполнение. По истечении времени от каждой подгруппы вызывается ученик, который должен объяснить решение (если необходимо, то ему помогает вся группа). Такая групповая работа несет в себе массу достоинств. Во-первых, каждый ученик старается разобраться в решении задачи (неважно самостоятельно или с помощью товарищей), поскольку никто не знает, кто будет вызван к доске. Во-вторых, «сильные» помогают «слабым», тем самым, закрепляя свои знания, в то время, как «слабые» разбираются в неясных вопросах, т. е. получают консультанта. В-третьих, каждый, чтобы не потерять чувство «собственного достоинства» при работе в группе старается добросовестно подготовить теоретический материал дома.

Провокационные вопросы. Как только большая часть учащихся справится с решением, заданного им задания, к доске вызывается один из них. Решение каждого задания проверяется, а также выясняются затруднения, возникшие в ходе решения задач, у доски. Преподаватель все неоднозначные моменты, которые существуют в ходе решения задания, и которые могут привести к неправильному решению, в виде вопросов спрашивает у учащихся, вызывая тем самым класс на высказывание и доказательство своих взглядов. Этим самым у учеников, во-первых, формируется умение быть открытым (не бояться высказываться), умение сомневаться, умение критично воспринимать проблему и т. д., во-вторых, развиваются такие механизмы творческой работы, как анализ, синтез, интуиция и т. п.

На занятиях директориальные синтезированные игры могут быть применены как сюжетная единая линия в течение всего занятия, так и на отдельных его этапах.

Итак, сформировать и развить аппарат творчества школьников, необходимый для решения нестандартных задач в течение всей жизни человека, - это проблема, которая требует своего разрешения. Компоненты аппарата творчества приводят к состоянию «творчество - озарение». Одни из них даны от рождения человеку (например, способности) и их надо развить и связать с другими частями творчества, чтобы получилось одно целое. Другие вначале надо сформировать, а затем постоянно развивать, например, умения творческой самостоятельной работы. 
Правила построения директориальной синтезированной игры

\begin{tabular}{|c|c|}
\hline Сюжет игры & $\begin{array}{c}\text { Содержание } \\
\text { учебного материала }\end{array}$ \\
\hline $\begin{array}{l}\text { - Имеет проблемно - поисковый характер, } \\
\text { с элементами соревнования. } \\
\text { - Ставится конкретная цель. } \\
\text { - Учитываются } 4 \text { уровня сформированности } \\
\text { синоптического синтеза за счет управления про- } \\
\text { цессом: } \\
1,2 \text { уровень - учитель управляет процессом (по- } \\
\text { ясняет); } \\
3 \text { уровень - самостоятельная работа с наводящи- } \\
\text { ми вопросами учителя; } \\
4 \text { уровень - самостоятельная работа без какой- } \\
\text { либо помощи учителя. } \\
\text { - Поощряется фантазия, воображение. }\end{array}$ & $\begin{array}{l}\text { - Эвристические задания (с по- } \\
\text { мощью наводящих вопросов). } \\
\text { - Задания с противопостав- } \\
\text { лениями. } \\
\text { - Задания конкурсного } \\
\text { характера. } \\
\text { - Задания по составлению } \\
\text { новых вопросов, суждений. } \\
\text { - Задания по составлению } \\
\text { собственной оценки. } \\
\text { - Задания на раскрытие } \\
\text { новых сторон явления. } \\
\text { - Задания на видоизменение } \\
\text { структуры явления. }\end{array}$ \\
\hline \multicolumn{2}{|l|}{ Средства достижения результатов } \\
\hline $\begin{array}{l}\text { 1. Сопоставление: начиная от одного предмета, } \\
\text { явления и т. п. и устанавливая оригинальные } \\
\text { соответствия между ним и его различными ха- } \\
\text { рактеристиками, объектами, и кончая нахожде- } \\
\text { нием различных зависимостей между многими } \\
\text { объектами, явлениями и т. п. } \\
\text { 2. Нахождение связей по аналогии. Рассматри- } \\
\text { ваются решения нескольких заданий, и по их } \\
\text { аналогии дается задание, с нахождением ориги- } \\
\text { нальных связей между чем-либо. } \\
\end{array}$ & \\
\hline $\begin{array}{l}\text { 3. Контрастность: начиная от одного предмета, } \\
\text { явления и т. п. (находятся оригинальные несо- } \\
\text { ответствия между объектом и существующими } \\
\text { различными характеристиками и устанавливается } \\
\text { связь между ними) и кончая нахождением раз- } \\
\text { личных зависимостей между многими объектами. } \\
\text { 4. Смена трудности. Направление работы часто } \\
\text { меняется от простого к сложному и от сложно- } \\
\text { го к простому. } \\
\text { 5. Варьирование объемом материала - от узко } \\
\text { выученного кусочка до широкого знания об } \\
\text { этом предмете из разных источников. } \\
\text { 6. Различные сочетания трудности, объема } \\
\text { и скорости. } \\
\text { 7. В обязательном порядке, где возможно, во всех } \\
\text { средствах используются структурно-логические } \\
\text { схемы, показывающие связи. }\end{array}$ & \\
\hline
\end{tabular}




\section{Библиографический список:}

1. Абрамова Г.С. Возрастная психология: учеб. пособие для студ. вузов / Г.С. Абрамова. - М.: Акад. проект; Екатеринбург: Деловая книга, 2000. $-624 \mathrm{c}$.

2. Бехтерев В.М. Личность художника в рефлексологическом освещении / В.М. Бехтерев // Апека: сб. - Л.: Время, 1924. - 65 с.

3. Блонский П.П. Избранные педагогические сочинения: в 2 т./ П.П. Блонский. - М.: Педагогика, 1979.

4. Выготский Л.С. Вопросы детской психологии / Л.С. Выготский. СПб.: СОЮЗ, 1997. - 224 с.

5. Грузенберг С.О. Гений и творчество / С.О. Грузенберг // Основы теории и психологии творчества. - Л.: Изд-во П.П. Сойкина, 1924. - 251 с.

6. Дрозина В.В. Контекстно-интенсифицированный подход к организации творческой самостоятельной деятельности: теория и практика. Монография / В.В. Дрозина. - Челябинск: «Факел», 1998. - 174с.

7. Дрозина В.В. Синоптический синтез - основополагающий компонент творчества: теория и практика. Монография / В.В. Дрозина. Челябинск, ЧГПУ, 2003. - 210 с.

8. Дрозина В.В. Механизм творчества решения нестандартных задач. Руководство для тех, кто хочет научиться решать нестандартные задачи: учебное пособие / В.В. Дрозина, В.Л. Дильман. - М.: БИНОМ. Лаборатория знаний, 2015. - 255 с. (Гриф НМС МОиН РФ).

9. Дрозина В.В. Как научить младших школьников решать нестандартные задачи / В.В. Дрозина, В.Л. Дильман, Д.А. Дрозин - M.: URSS, 2015. - 240 с. (Гриф НМС МОиН РФ).

10. Калошина И.П. Структура и механизмы творческой деятельности / И.П. Калошина. - М.: Изд-во Моск. гос. ун-та, 1983. - 168 с.

11. Лук А.Н. Психология творчества /А.Н. Лук. - М.: Наука, 1978. - $127 \mathrm{c}$. 


\section{Гдава 2. ПОДГОТОВКА БУДУЩИХ ПЕДАГОГОВ К РЕАЯИЗАЦИИ ФЕДЕРАЯЬНЫХ ГОСУ ДАРСТВЕННЫХ СТАНДАРТОВ}

\section{СОВРЕМЕННЫЕ ТЕХНОЛОГИИ РАЗВИТИЯ ТВОРЧЕСКОГО ПОТЕНЦИАЛА БУДУЩЕГО УЧИТЕЛЯ НАЧАЛЬНЫХ КЛАССОВ}

Л.Г. Махмутова

В статье освещаются современные образовательные технологии, используемые в высшей школе при обучении будущих учителей начальных классов. Применение этих технологий позволяет не только работать с информацией, обучаться в сотрудничестве, но и развивает творческий потенциал и исследовательские навыки.

Ключевой особенностью школы будущего являются чуткие, внимательные и восприимчивые к интересам школьников, открытые ко всему новому учителя. Задача современного учителя - помочь ученикам найти себя в будущем, стать самостоятельными, творческими и уверенными в себе людьми.

Учитывая то, что для учащихся начальной школы педагог вообще выступает как главная, наиболее авторитетная фигура в их учебной жизни, очевидно, что творческий потенциал ученика зависит от творческого потенциала самого учителя. При этом в современной школе следует обеспечить изучение не только достижений прошлого, но и технологий, которые пригодятся в будущем. Учащиеся должны быть вовлечены в исследовательские проекты и творческие занятия, чтобы научиться изобретать, понимать и осваивать новое, выражать собственные мысли, принимать решения и помогать друг другу, формулировать интересы и осознавать возможности. Достижение нового качества результатов образования учащихся в значительной степени определяется не только обновлением содержания образования, но и эффективностью применяемых учителем педагогических технологий.

В этой связи одной из задач подготовки будущих учителей начальных классов является освоение наиболее распространенных педагогических технологий с точки зрения их направленности на достижение у учащихся новых образовательных результатов. Сегодня перед школой остро встала и в настоящее время остаётся актуальной проблема самостоя- 
тельного успешного усвоения учащимися новых знаний, умений и компетенций, включая умение учиться. Большие возможности для этого предоставляет освоение универсальных учебных действий (УУД). Принципиальным отличием федеральных государственных образовательных стандартов начального общего образования второго поколения является их ориентация на достижение не только предметных образовательных результатов, но, прежде всего, на формирование личности учащихся, овладение ими универсальными способами учебной деятельности, обеспечивающими успешность в познавательной деятельности на всех этапах дальнейшего образования.

В широком смысле термин «универсальные учебные действия» означает умение учиться, т. е. способность субъекта к саморазвитию и самосовершенствованию путем сознательного и активного присвоения нового социального опыта. В более узком (собственно психологическом значении) этот термин можно определить как совокупность способов действия учащегося (а также связанных с ним навыков учебной работы), обеспечивающих его способность к самостоятельному усвоению новых знаний и умений, включая организацию этого процесса. Способность учащегося самостоятельно успешно усваивать новые знания, формировать умения и компетентности, включая самостоятельную организацию процесса усвоения, т. е. умение учиться, обеспечивается тем, что УУД как обобщенные действия открывают возможность широкой ориентации как в различных предметных областях, так и в строении самой учебной деятельности, включая осознание ее целевой направленности, ценностно-смысловых и операциональных характеристик [6, с. 27]. При этом универсальный характер учебных действий проявляется в том, что они надпредметны, обеспечивают целостность общекультурного, личностного и познавательного развития и саморазвития, лежат в основе организации и регуляции любой деятельности учащегося независимо от ее специального предметного содержания.

В этой связи отметим, что обучение студентов также должно проходить с опорой на те образовательные технологии, которые рекомендуется активно применять в начальной школе (кейс-технология, игровая технология, обучение в сотрудничестве, проектное обучение, «Шесть шляп мышления» и др.). Информация о них содержится во множестве источников $[1 ; 2 ; 7 ; 8 ; 11 ; 13]$.

Главная цель применения современных педагогических технологий - придание познавательной деятельности на уроке характеристик интереса, активности, мотивированного выбора вариантов решения задачи. Учителю начальных классов следует быть знакомым с различными 
видами педагогических технологий, нацеленными на формирование личностных, регулятивных, познавательных, коммуникативных универсальных учебных действий. В условиях компетентностного обучения наиболее актуальными становятся технологии развития умственной деятельности, основными чертами которых выступают процессуально-целевая ориентация; относительная целостность; ориентация учащихся на самостоятельное освоение нового опыта, развитие своих познавательных возможностей; представление процесса обучения как творческого поиска решения познавательных задач; познавательная рефлексия над результатом и процессом познания; активная позиция учащегося в процессе обучения (самостоятельный выбор вариантов решения, принятие решений, оценочная деятельность); позиция педагога как «партнера по учебному исследованию»; измеряемость и воспроизводимость результатов. Среди технологий данного вида предметом обсуждения на практических занятиях по педагогике и методикам преподавания различных предметов могут стать:

- Кейс-технология [2; 13]. Это технология анализа конкретных ситуаций, в основе которой лежит имитационное моделирование, разработка конкретного примера или использование готовых материалов с описанием реальной профессиональной деятельности (например, анализ явлений и объектов любой науки и практики, исследовательский проект, разнообразные статистические материалы, прогноз событий). При этом наблюдается ориентация на конкретные, практические проблемы, которые призваны решать специалисты многих сфер деятельности (поэтому она весьма актуальна в профильном обучении).

- Исследовательская технология обучения [2; 3]. Подразумевает организацию поисковой, познавательной деятельности учащихся путем постановки учителем познавательных и практических задач, требующих самостоятельного творческого решения. Важно помнить, что педагог консультирует, советует, направляет, наталкивает на возможные выводы, но ни в коем случае не диктует и не пишет работу за ученика. При этом учащиеся осваивают структуру учебного исследования (выявление и постановка проблемы исследования; формулирование гипотезы; планирование и разработка исследовательских действий; сбор данных, их анализ и синтез; сопоставление данных и умозаключений, их проверка; подготовка и написание отчета).

При обучении студентов - будущих учителей начальных классов в рамках изучения дисциплины «Методика обучения математике в начальной школе» к кейс-технологии мы обращаемся при работе над модулем «Методика обучения решению текстовых задач в начальной школе». 
В данном случае текстовая задача вполне сопоставима с понятием кейса как задания. В методике обучения математике задачей в широком смысле называют любое задание. С точки зрения Л.М. Фридмана [16, с. 158-160], известного педагога и методиста по математике, функциями решения сюжетных задач являются вводно-мотивационная, иллюстративная и конкретизирующая, применения и использования математических закономерностей, формирования умений и навыков, формирования общеучебных умений, контрольно-оценочная, воспитания характера и воли учащихся, развития творческого мышления и воображения. Все эти функции могут быть реализованы в процессе решения не только современных задач, взятых из действующих учебников и методических материалов, но и старинных занимательных, так называемых народных задач, обладающих большим потенциалом как для студентов, так и для их будущих учеников.

Народные задачи могут оказать большую помощь учителю начальных классов в обеспечении мотивационного фона при решении задач. Как правило, в подобных заданиях уже из контекста ясно, зачем нужно рассчитать что-либо. Например, греческая задача [16, с. 8-9]: «Ослица и мул шли бок о бок с тяжелой поклажей на спине. Ослица жаловалась на свою непомерно тяжелую ношу. «Чего ты жалуешься? - ответил ей мул. - Ведь если я возьму у тебя один мешок, ноша моя станет вдвое тяжелей твоей. А вот если бы ты сняла с моей спины один мешок, твоя поклажа стала бы одинакова с моей». Сколько мешков несла ослица и сколько нес мул?» А вот старинная русская задача «Из Москвы в Вологду» из «Арифметики» Л.Ф. Магницкого 1703 г. [9, с. 17]: «Послан человек из Москвы в Вологду, и велено ему в хождении своем совершать во всякий день по 40 верст. На следующий день вслед ему послан второй человек, и приказано ему проходить в день по 45 верст. На какой день второй человек догонит первого?» Или задача «Сколько стоит кафтан?» [9, с. 21]: «Хозяин нанял работника на год и обещал ему дать 12 рублей и кафтан. Но тот, проработав только 7 месяцев, захотел уйти. При расчете он получил кафтан и 5 рублей. Сколько стоит кафтан?»

Сегодня можно провести параллель между старинными занимательными задачами и заданиями, которые даются современным школьникам при международных исследованиях учебных достижений учащихся разных стран, в том числе и России (например, TIMSS, PISA [17; 18]). Основной акцент в таких заданиях делается на применение полученных математических знаний в конкретных жизненных ситуациях.

В Концепции федеральных государственных образовательных стандартов общего образования делается акцент на организацию учебного 
взаимодействия учащихся, что является следствием деятельностной парадигмы образования. В этом плане серьезным педагогическим потенциалом обладают технологии группового обучения. Интерес к групповым формам обучения повысился в начале 90-х гг. XX века. Известно, что уровень усвоения материала при работе в группах может достигать $50 \%$, но главное - не только в уровне знаний, а также в том, что в ситуации делового общения и сотрудничества происходит самораскрытие и саморазвитие личности.

Среди технологий группового обучения можно рассмотреть следующие:

- Проектное обучение (групповые проекты) [2; 10; 11; 14]. Цель данного обучения - создать условия, при которых учащиеся: самостоятельно и охотно приобретают недостающие знания из разных источников; учатся пользоваться приобретенными знаниями для решения познавательных и практических задач; приобретают коммуникативные умения, работая в различных группах; развивают исследовательские умения; развивают системное мышление. Выделяют следующие стадии разработки проекта:

1) Разработка проектного задания (выбор темы проекта; выделение подтем в темах проекта; формирование творческих групп; подготовка материалов к исследовательской работе - формулировка вопросов, на которые нужно ответить, задание для команд, отбор литературы; определение форм выражения итогов проектной деятельности).

2) Разработка проекта.

3) Оформление результатов.

4) Презентация.

5) Рефлексия.

Обучение в сотрудничестве (cooperative learning) [13]. Так в современной зарубежной педагогической литературе называют работу в малых группах. Эта форма организации обучения распространена в школах США, Англии, Канады, Японии, Израиля и других странах. При разработке занятий следует помнить, что основные идеи на уроке - общность цели и задач, индивидуальная ответственность и равные возможности успеха. Именно сотрудничество, а не соревнование лежит в основе обучения в группе.

Представим работу в рамках технологии обучения в сотрудничестве на занятии по методике обучения математике в начальной школе в рамках темы «Интегративные связи курса математики начальной школы с другими учебными предметами». По данной теме запланирована экскурсия в Музей леса г. Челябинска студентов 4 курса факультета подготовки учителей начальных классов. При этом студенты предварительно получают инструктаж от преподавателя о распределении заданий. 
Цели экскурсии:

- знакомство с интегративными связями уроков математики и окружающего мира в начальной школе;

- оценка возможностей музейной сферы г. Челябинска в организации и проведении экскурсий для младших школьников.

Основание для проведения экскурсии: распоряжение декана факультета (указывается номер и дата распоряжения).

Устанавливается дата проведения экскурсии, время и место сбора. Вводную беседу и инструктаж по технике безопасности проводит преподаватель.

Задание для студентов (выполняется в парах):

1. Во время проведения экскурсии каждому фиксировать информацию от экскурсовода.

2. В конспекте отразить возможности предмета «Окружающий мир» для обеспечения содержательной стороны уроков математики, а также для усиления воспитательной значимости уроков математики в начальной школе. Свои мысли отразить в стенгазете «Мы были в Музе леса», которую нужно разместить в коридоре факультета (устанавливается срок сдачи газеты).

3. Также в конспекте отметить, насколько доступна, по Вашему мнению, информация, подаваемая экскурсоводом, для детей младшего школьного возраста.

4. Определить, какая пара студентов будет готовить статью в университетскую газету «Молодой Учитель» с описанием экскурсии. Для них задание № 5 отменено (устанавливается срок выполнения).

5. Определить, какое животное, представленное в Музее леса, вы выберите для составления интегративных заданий по математике и окружающего мира для младших школьников. Вписать его в таблицу, приведенную ниже:

\begin{tabular}{|c|c|c|}
\hline $\begin{array}{l}\text { № } \\
\text { П/ח }\end{array}$ & Ф.И.О. студентов & Животное (для составления заданий) \\
\hline 1. & $\begin{array}{l}1 . \\
2 .\end{array}$ & \\
\hline 2. & $\begin{array}{l}1 . \\
2 .\end{array}$ & \\
\hline$n$. & $\begin{array}{l}1 . \\
2 .\end{array}$ & $\begin{array}{l}\text { Вместо составления заданий про животное - статья } \\
\text { в университетскую газету «Молодой Учитель» }\end{array}$ \\
\hline
\end{tabular}

Само задание:

Сначала подобрать адаптированный для младших школьников текст о животном (из энциклопедии, справочника, учебника, Интернета, книг о животных и т. д. с обязательным указанием использованных источников). 
Составить к тексту 4-5 заданий по математике для младших школьников с опорой на информацию о выбранном животном (устанавливается срок выполнения).

Примечание: можно воспользоваться образцами практических задач по математике, представленных, например, в сборнике УМК «Перспективная начальная школа» [5].

Кроме названных, популярными сегодня в свете решения задач, которые общество ставит перед образованием, являются диалоговые технологии развития творческих способностей обучающихся. Среди них выделим следующие:

Обучение, погруженное в общение $[11 ; 13]$. Термин «интерактивность» (или «открытость к общению») в последнее время включается в оборот педагогической науки как признание необходимости равноактивного общения субъектов образовательного процесса учителя и учащихся, общение, основанное на диалоговых формах процесса познания. Здесь нужно учитывать, что диалог понимается как форма взаимной деятельности учителей и учащихся с учетом их индивидуальностей, своеобразия воззрений и отношений с миром; диалог - это возможность взаимодействия друг с другом, предполагающая: равенство позиций участников, уважение и доверие друг к другу; готовность принимать позицию другого человека; особую атмосферу, способствующую искренности в выражении мыслей и чувств.

Технологии игрового обучения [2; $3 ; 11]$. В отличие от традиционного обучения, где дидактические игры выполняют вспомогательную роль (иллюстрации, стимулирование интереса, эмоционально-привлекательный фон), в развивающем обучении учебная игра моделирует процесс исследования реальной или имитационной проблемной ситуации, самостоятельного принятия решения в соответствии с правилами игры и моделью социального взаимодействия, оценочную деятельность при анализе принятых решений и достигнутых результатов (в том числе учебных). Варианты технологий на основе учебной игры различаются по целевой направленности, способу моделирования, содержанию деятельности, детерминированности деятельности участников правилами или руководством учителя, степенью имитации реальных проблем и процессов и т. д. Важно помнить, что инвариантными элементами учебного процесса на основе учебной игры являются следующие этапы: ориентация (педагог представляет изучаемую тему, знакомит с основными положениями, которые в ней используются; дает характеристику имитации 
и игровых правил, общий обзор хода игры); подготовка к проведению (педагог излагает сценарий, останавливаясь на игровых задачах, правилах, ролях, игровых процедурах, правилах подсчета очков, примерном типе решения в ходе игры; между участниками распределяются роли; каждому участнику вручается функциональное описание роли и его задачи, что повышает эффективность и организованность игры; создается игровая атрибутика); проведение игры.

Примером применения игровой технологии может стать проведение деловой игры в жанре турнира эрудитов «Знатоки методики обучения математике в начальной школе». Игра проводится для студентов 3 курса и имеет своей целью обобщить знания студентов по основным разделам методики обучения математике (в рамках изученных тем) перед выходом на первую педагогическую практику в качестве учителя начальных классов. Подготовка: примерно за 1 месяц группе сообщается о проведении игры и запрашивается состав участников команд (не менее 3 команд). Кроме того, отдельно готовятся двое ведущих.

Команды получают информацию о содержании и условиях оценивания выступлений. Название и содержание конкурсов, а также параметры оценивания и правила начисления баллов приведены в табл. 2.

Таблица 2

Описание конкурсов турнира эрудитов «Знатоки методики обучения математике в начальной школе»

\begin{tabular}{|c|c|c|c|}
\hline $\begin{array}{c}\text { № } \\
\Pi / \Pi\end{array}$ & $\begin{array}{l}\text { Название } \\
\text { конкурса }\end{array}$ & Содержание конкурса & $\begin{array}{c}\text { Параметры оценивания и правила } \\
\text { начисления баллов }\end{array}$ \\
\hline 1. & $\begin{array}{l}\text { Привет- } \\
\text { ствие }\end{array}$ & $\begin{array}{l}\text { Название } \\
\text { Девиз } \\
\text { Символика } \\
\text { Наличие бейджиков } \\
\text { с именем и отчеством }\end{array}$ & $\begin{array}{l}\text { Оценивается наличие, соответствие } \\
\text { тематике Турнира, творческий подход, } \\
\text { максимум - } 5 \text { баллов. } \\
\text { Оценивается отдельно - } 1 \text { балл, если } \\
\text { у всех членов команды есть бейджи; } \\
0 \text { баллов - если хотя бы у одного } \\
\text { его нет. }\end{array}$ \\
\hline 2. & Вели & $\begin{array}{l}\text { Перевод единиц, } \\
\text { действия с именован- } \\
\text { ными числами }\end{array}$ & $\begin{array}{l}\text { Максимум - } 6 \text { баллов, за каждую ошиб- } \\
\text { ку снимается } 1 \text { балл; за скорость выпол- } \\
\text { нения может быть начислен } 1 \text { балл. } \\
\end{array}$ \\
\hline 3. & $\begin{array}{l}\text { Цифровая } \\
\text { каллигра- } \\
\text { фия }\end{array}$ & $\begin{array}{l}\text { Прописи цифр } \\
\text { и текста на доске и на } \\
\text { листах в клетку }\end{array}$ & $\begin{array}{l}\text { Максимум - } 6 \text { баллов, оценивается } \\
\text { правильность написания цифр, акку- } \\
\text { ратность, соразмерность элементов }\end{array}$ \\
\hline
\end{tabular}




\begin{tabular}{|c|c|c|c|}
\hline \begin{tabular}{|l} 
№ \\
П/ח
\end{tabular} & $\begin{array}{l}\text { Название } \\
\text { конкурса }\end{array}$ & Содержание конкурса & $\begin{array}{c}\text { Параметры оценивания и правила } \\
\text { начисления баллов }\end{array}$ \\
\hline 4. & $\begin{array}{l}\text { Устные } \\
\text { и пись- } \\
\text { менные } \\
\text { вычисле- } \\
\text { ния }\end{array}$ & $\begin{array}{l}\text { Для каждой команды } \\
2 \text { примера: } \\
\text { 1) разбор устного } \\
\text { приема вычисления } \\
\text { с записью у доски; } \\
\text { 2) разбор письменного } \\
\text { приема - алгоритм } \\
\text { вычислений в столбик } \\
\text { (выполняют } 2 \text { челове- } \\
\text { ка у доски. }\end{array}$ & $\begin{array}{l}\text { Максимум - } 6 \text { баллов, по } 3 \text { за каждый } \\
\text { прием; оценивается правильность } \\
\text { записи и решения, грамотность речи, } \\
\text { последовательность выполнения; за } \\
\text { ошибки баллы могут быть сняты. }\end{array}$ \\
\hline 5. & \begin{tabular}{|l|} 
Конкурс \\
физмину- \\
ток «Кто \\
больше?»
\end{tabular} & $\begin{array}{l}\text { Команды поочерёдно } \\
\text { по одному называ- } \\
\text { ют физминутки без } \\
\text { повторений и демон- } \\
\text { стрируют движения. }\end{array}$ & $\begin{array}{l}\text { Выигрывает та команда, которая на- } \\
\text { зовёт последнюю физминутку. } \\
\text { Команда-победитель получает } 6 \text { бал- } \\
\text { лов, 2-я команда - } 4 \text { балла; } 3 \text {-я ко- } \\
\text { манда - } 2 \text { балла. } \\
\text { Баллы могут быть не начислены, если } \\
\text { физминутки не названы вообще. }\end{array}$ \\
\hline 6. & $\begin{array}{l}\text { Конкурс } \\
\text { капитанов }\end{array}$ & $\begin{array}{l}\text { Работа над простой } \\
\text { задачей: капитаны } \\
\text { должны определить } \\
\text { тип задачи и провести } \\
\text { методический разбор } \\
\text { задачи. }\end{array}$ & $\begin{array}{l}\text { Максимум - } 6 \text { баллов, оценивает- } \\
\text { ся правильность определения типа } \\
\text { задачи и грамотность в выполнении } \\
\text { разбора задачи. }\end{array}$ \\
\hline 7. & $\begin{array}{l}\text { Матема- } \\
\text { тический } \\
\text { диктант }\end{array}$ & $\begin{array}{l}\text { Устные вычисления - } \\
10 \text { примеров: работа } \\
1 \text { человека на листах - } \\
\text { запись только ответа. }\end{array}$ & $\begin{array}{l}\text { Максимум - } 5 \text { баллов (по 0,5 балла } \\
\text { за правильность выполнения одного } \\
\text { примера), параллельно идёт следую- } \\
\text { щий конкурс - см. п. } 8 .\end{array}$ \\
\hline 8. & $\begin{array}{l}\text { Решение } \\
\text { уравнения }\end{array}$ & $\begin{array}{l}\text { На доске один из } \\
\text { участников команды } \\
\text { решает уравнение, } \\
\text { которое записано на } \\
\text { карточке. }\end{array}$ & $\begin{array}{l}\text { Максимум - } 5 \text { баллов; оценивается } \\
\text { грамотность работы над уравнением, } \\
\text { отсутствие ошибок - иначе баллы } \\
\text { могут быть сняты, полнота всех этапов } \\
\text { работы над уравнением. }\end{array}$ \\
\hline
\end{tabular}

В качестве членов жюри привлекаются преподаватели по методикам обучения предметов в начальной школе (обязательно по методике обучения математике), а также преподаватели по математике.

В ходе игры моделируются ситуации, с которыми студенты встретятся на практике, то есть моделируется перенос знаний из учебной среды в реальную, при этом обучающимся нужно незамедлительно принять конкретное решение (определить тип задачи, выполнить разбор уравнения и т. д.) по выполнению задания, которое они видят впервые. 
В ходе подготовки к такой игре наблюдается сплочение участников команды, а главное - их обращение к темам дисциплины, осознание теоретических основ методических вопросов, детальный разбор затруднительных моментов.

Обращение к диалоговым технологии обучения весьма актуально при реализации дисциплин по выбору по вариативным системам обучения в начальной школе, реализуемых на выпускном курсе бакалавриата: «Психолого-педагогические основы вариативного обучения в начальной школе», «Методические основы обучения русскому языку и литературе в вариативных системах начального образования», «Методические основы обучения математике в вариативных системах начального образования», «Методические основы обучения естествознанию в вариативных системах начального образования». Преподавание данных дисциплин по выбору происходит одновременно. Студенты к этому времени уже имеют багаж накопленных за предыдущие курсы теоретических знаний и опыт, полученный на педагогической практике. В этой связи они могут не только воспринимать информацию, пусть и подаваемую с помощью различных активных методов обучения, но и приводить примеры из практики, включаться в диалог, демонстрируя свое отношение и уточняя ключевые моменты тех или иных вариативных систем начального образования. В период, предшествующий выпуску и трудоустройству, наблюдается явная заинтересованность при получении знаний и обсуждении методических особенностей систем обучения, действующих в начальной школе.

Подробнее представим работу в рамках технологии развития критического мышления через чтение и письмо $[2 ; 4 ; 10]$. Среди преимуществ указанной технологии - развитие навыков критического анализа (при этом под критическим мышлением подразумевается не поиск негативных сторон объекта, а стремление проверить информацию, уточнить ее, рассмотреть полученные данные с разных позиций), активизация образовательного процесса, повышение самостоятельности обучаемых, учет их индивидуальных особенностей в процессе работы с информацией, формирование личностного отношения к изучаемому материалу.

Процесс обучения в рамках технологии развития критического мышления строится на основе смены трех фаз (этапов). На первой фазе - вызова - студенты «вспоминают», что им известно по изучаемому вопросу, систематизируют информацию до ее изучения; задают вопросы, на которые хотели бы получить ответ, формулируют собственные цели. Следующая фаза - осмысления - является основной. Обучаемые читают (слушают) текст, используя предложенные преподавателем активные методы чтения, делают пометки на полях или ведут записи по мере осмысления 
новой информации, отслеживают понимание при работе с изучаемым материалом, активно конструируют (корректируют) цели своего учения. Фаза рефлексии считается завершающей. Студенты соотносят получаемую информацию с уже известной, используя знания, приобретенные на стадии осмысления. Производят отбор информации, наиболее значимой для реализации сформулированной ранее индивидуально цели учения, самостоятельно выстраивают причинно-следственные связи.

На занятиях по методике обучения математике в начальной школе обращение к технологии развития критического мышления не просто возможно, но и необходимо, особенно учитывая то, что студенты могут работать в группах, а это обычно вызывает повышенную активность, заинтересованность, ответственность за получение и представление качественного результата своей работы.

При изучении темы «Организационные формы учебной работы по математике в начальных классах» после знакомства студентов со значением и методикой проведения экскурсий по математике в начальной школе [15] целесообразно организовать работу в группах, во время которой обучаемые будут строить кластеры по различных содержательным направлениям математических экскурсий. Кластер (от англ. - гроздь) это способ графической организации материала, позволяющий сделать наглядными те мыслительные процессы, которые происходят при погружении в тот или иной текст. Последовательность действий при построении кластера проста и логична:

1. Посередине чистого листа (классной доски) написать ключевое слово или тезис, которые являются «сердцем» текста.

2. Вокруг «накидать» слова или предложения, выражающие идеи, факты, образы, подходящие для данной темы («планета и ее спутники»).

3. Эти слова или предложения соединить прямыми линиями с »ердцем» текста. У каждого из «спутников», в свою очередь, тоже появляются «спутники», устанавливаются новые логические связи. В итоге получается структура, которая графически отображает размышления, определяет информационное поле данного текста. В нашем случае студенты высказывают свои соображения по теме «Содержание математических экскурсий в начальной школе», возникшие после прочтения текста, группируют их, рисуя маркерами некоторое подобие грозди винограда на больших листах. При этом в группе формируется общее мнение. Среди тем, предназначенных для совместного прочтения и обсуждения, следующие: «Отношения», «Числа и их запись», «Арифметические действия», «Алгебраический материал», «Средства измерения», «Задача и ее решение», «Геометрический материал». На заключительном этапе группы 
представляют свои разработки, отвечая на вопросы студентов и преподавателя. Следует отметить, что обсуждение этой темы всегда проходит красочно в прямом и переносном смысле. Имеет смысл дополнить данный прием технологиями «Коллаж» и »Шесть шляп мышления».

Преподавателю лучше предусмотреть, чтобы количество отрывков текста совпадало с числом человек в группе. В этом случае уместно применить и такую стратегию, как «Зигзаг», где каждый член группы становится экспертом по какому-то вопросу. На стадии осмысления обучаемые делятся на группы, читают текст, не вдаваясь в детали, и кратко его обсуждают. Каждому члену группы выдается свой экспертный лист, обучающиеся работают со своим отрывком, составляя опорный конспект. Затем они создают новые группы - группы экспертов, в которых объединены «специалисты» по отдельным вопросам. Их задачей является вторичное чтение текста, отбор материала и его структурирование, дополнение, подготовка и представление данного фрагмента в своих рабочих группах и подготовка к презентации. На стадии рефлексии студенты возвращаются в свои «родные» группы и по очереди объясняют другим членам группы свой отрывок, пользуясь общей презентационной схемой. На общей презентации особое внимание уделяется трудным вопросам.

Отметим, что мы использовали технологию развития критического мышления лишь на практических занятиях. Однако на лекциях применение методов и приемов данной технологии также возможно (например, стратегия «Бортовой журнал» совмещает прослушивание студентом лекционного материала и самостоятельную работу обучаемого).

Отличительной особенностью урока в современной школе является то обстоятельство, что использование различного рода технологий, методов и приемов обучения учащихся осуществляется в условиях ИКТ-насыщенной образовательной среды. В настоящее время различными разработчиками создано достаточно большое количество учебных материалов на цифровой основе, так называемых цифровых образовательных ресурсов. Хотя правильнее их назвать электронными учебными материалами (или ресурсами) нового поколения. Конечно, использование компьютеров не является главной целью. Как отмечает М.М. Поташник [12, с. 130], сам факт использования или неиспользования компьютеров (без специального анализа) ничего не говорит о результативности урока и не может служить основанием положительной оценки урока. Важно, чтобы учитель видел очевидные преимущества использования электронных учебных материалов, в том числе электронных учебников, в педагогической практике. А ведь они бесспорны: экономия времени, индивидуализация обучения, наличие обучающих и контролирующих 
программ, динамическая наглядность (построение геометрических фигур, задачи на движение и т. д.).

Безусловно, студентам недостаточно получения знаний только из лекций и семинаров. Целесообразно обращение преподавателей высшей школы к организации самостоятельной работы студентов по исследованию вопросов, связанных с процессом формирования универсальных учебных действий и предметных результатов. При этом необходимо учитывать, что самостоятельная работа - это не только самостоятельное выполнение заданий, полученных от преподавателя, но и инициативная, творческая работа обучающегося по развитию своих способностей, удовлетворению профессиональных потребностей, самопознанию и осмыслению профессии.

Итак, важным условием формирования у младших школьников универсальных учебных действий является грамотное использование учителем современных образовательных технологий. При подготовке студентов - будущих учителей начальных классов - следует не только знакомить их с современными технологиями, применяемыми в начальной школе (кейс-технология, игровая технология, проектное обучение и др.), но и проводить обучение с помощью этих технологий. Они не только содействуют формированию умений критического анализа, помогают эффективнее осмыслить и запомнить материал, но и развивают исследовательский и творческий потенциал обучаемых, а при работе в группах реализуют также социальную и коммуникативную функции.

\section{Библиографический список:}

1. Гузеев, В. В. Познавательная самостоятельность учащихся и развитие образовательной технологии [Текст] / В. В. Гузеев. - М. : НИИ школьных технологий, 2004. - 128 с.

2. Даутова, О. Б. Современные педагогические технологии в профильном обучении [Текст]: учеб.-метод. пособие для учителей / О. Б. Даутова, О. Н. Крылова; под ред. А. П. Тряпицыной. - СПб. : KAPO, 2006. - $176 \mathrm{c}$.

3. Загвязинский, В. И. Теория обучения: Современная интерпретация [Текст] / В. И. Загвязинский. - М. : изд. центр «Академия», 2004. - 192 с.

4. Заир-Бек, С. И. Развитие критического мышления на уроке [Текст]: пособие для учителя / С. И. Заир-Бек, И. В. Муштавинская. М. : Просвешение, 2004. - 175 с.

5. Захарова, О. А. Практические задачи по математике. Подготовка к олимпиаде [Текст] : 3-й класс : учеб. пособие / О.А. Захарова; под ред. Р.Г. Чураковой. - М. : Академкнига/Учебник, 2010. - 64 с. 
6. Как проектировать универсальные учебные действия в начальной школе: от действия к мысли [Текст] / А. Г. Асмолов и др. - М. : Просвещение, 2011. - 151 с. - (Стандарты второго поколения).

7. Лакоценина, Т. П. Современный урок. Часть 4 [Текст] : практич. пособие / Т. П. Лакоценина, Е. Е. Алимова, Л. М. Оганезова. - Ростов н/Д. : Учитель, 2007. - 240 с.

8. Морева, Н. А. Современная технология учебного занятия [Текст] / Н. А. Морева. - М. : Просвешение, 2007. - 158 с.

9. Олехник, С. Н. Старинные занимательные задачи [Текст] / С. Н. Олехник, Ю. В. Нестеренко, М. К. Потапов. - М. : Наука. Гл. редакция физ.-мат. лит-ры, 1985. - 160 с.

10. Осмоловская, И. М. Дидактика [Текст] / И. М. Осмоловская. М. : изд. центр «Академия», 2006. - 240 с.

11. Педагогические технологии [Текст] : учеб. пособие / под общ. ред. В. С. Кукушина. - М. : ИКЦ «МарТ» : Ростов н/Д : изд. центр «MapT», 2006. - $336 \mathrm{c}$.

12. Поташник, М. М. Требования к современному уроку [Текст] : метод. пособие / М. М. Поташник. - М. : Центр педагогического образования, 2007. -272 c.

13. Селевко, Г. К. Энциклопедия образовательных технологий [Текст] : в 2 т. / Г. К. Селевко. - М. : НИИ школьных технологий, 2006.

14. Сергеев, И. С. Как организовать проектную деятельность учащихся [Текст]: практич. пособие / И. С. Сергеев. - М. : АРКТИ, 2006. $-80 \mathrm{c}$.

15. Смолеусова, Т. В. Уроки-экскурсии по математике в начальной школе [Текст] : метод. пособие / Т. В. Смолеусова. - М. : ТЦ Сфера, 2005. - $112 \mathrm{c}$.

16. Фридман, Л. М. Сюжетные задачи по математике. История, теория, методика [Текст] / Л. М. Фридман. - М. : Школьная Пресса, 2002. - 208 с.

17. http://www.centeroko.ru - Центр оценки качества образования Института содержания и методов обучения РАО.

18. http://www.timssandpirls.bc.edu - Международный координационный центр исследований «TIMSS and PIRLS». 


\title{
РЕАЛИЗАЦИЯ ЛИЧНОСТНЫХ ОСОБЕННОСТЕЙ УЧИТЕЛЕЙ И ОБУЧАЮЩИХСЯ В ОБРАЗОВАТЕЛЬНОМ ПРОЦЕССЕ
}

\author{
Н.А. Белоусова, Н.В. Мамылина
}

Для учителей активно занимающихся коммуникативной деятельностью, на определенном её этапе бывает характерным неожиданная потеря интереса к ней, появление формального отношения к своим обязанностям, наличие конфликтов с коллегами по непринципиальным вопросам. В дальнейшем у них обычно развиваются соматические заболевания и невротические расстройства. Причиной подобных изменений является длительное воздействие эмоционального стресса, приводящее к так называемому «синдрому профессионального (психического) выгорания», под которым понимается состояние физического, эмоционального, умственного истощения, проявляющееся в профессиях эмоциональной сферы [1, 2].

Необходимо отметить, что профессия учителя обладает огромной социальной важностью и требования общества к личности педагога возрастают с каждым годом. Способность к сопереживанию (эмпатии) признается одним из самых важных качеств учителя, но учителей зачастую не готовят к возможной эмоциональной перегрузке, целенаправленно не формируют у них соответствующих знаний, умений, личностных качеств, которые необходимы для преодоления эмоциональных трудностей профессии. Особенно это характерно для учителей начальных классов, которые в своей профессиональной деятельности имеют дело с детьми младшего школьного возраста, имеющими недостаточно сформированный психический статус личности, низкий уровень лабильности нервной системы, связанный с её функциональной незрелостью. В связи с этим профессиональный труд учителя начальных классов отличает очень высокая эмоциональная загруженность, предельно высокая ответственность, насыщенность факторами, вызывающими профессиональное выгорание.

Следует указать, что «синдром профессионального выгорания» включает в себя три основные составляющие: эмоциональную истощенность, деперсонализацию и редукцию профессиональных достижений.

Эмоциональное истощение ощущается учителем как эмоциональное перенапряжение, опустошенность, исчерпанность собственных эмоциональных ресурсов организма. Педагог чувствует, что уже не может 
полностью отдаваться работе как прежде, ощущает приглушенность, притупленность собственных эмоций, что может привести к эмоциональным срывам.

Деперсонализацию трактуют как тенденцию развития негативного, равнодушного отношения к раздражителям. В итоге в межличностных контактах педагога появляются обезличенность, формальность, негативные установки, имеющие скрытый характер, внутреннее сдерживаемое раздражение, которое со временем может проявляться наружу в виде вспышек раздражения или конфликтных ситуаций.

Редуцирование личных (персональных) достижений педагога может проявляться в виде снижения чувства компетентности в своей работе, недовольстве собой и окружающими, уменьшении ценности своей деятельности, негативном самовосприятии в профессиональной сфере. При этом у учителя может возникать чувство вины за собственные негативные проявления или чувства, снижаться профессиональная и личная самооценки, появляться чувство собственной несостоятельности и безразличия к работе.

Выделяются три основные стадии синдрома профессионального выгорания у учителя:

- для первой начальной стадии характерным является наличие у учителей незначительных сбоев на уровне выполнения отдельных функций, например, забывание внести нужную запись в документацию; вспомнить, задавался ли ученику планируемый вопрос; неточности в выполнении каких-либо двигательных действий и т. д. В результате этого учитель боится ошибиться, возрастает степень контроля за своими действиями, наблюдается многократная проверка выполнения рабочих действий на фоне ощущения нервно-психической напряженности;

- для второй стадии характерно снижение интереса к работе; потребности в общении с коллегами, учениками, друзьями; нарушение временной ориентации; нарастание апатии к концу недели; появление устойчивых соматических симптомов, сопровождающихся головными болями по вечерам, нарушением ритма сна, склонностью к простудным заболеваниям, повышенной раздражительностью;

- собственно личностное выгорание является третьей стадией описываемого синдрома. Для данной стадии характерны полная потеря интереса к своей профессиональной деятельности и окружающей жизни вообще, эмоциональное безразличие, нежелание видеть окружающих людей и общаться с ними, ощущение постоянного отсутствия сил.

Находясь на первых стадиях синдрома профессионального выгорания, учитель, как правило, не осознает его симптомы и изменения, их 
в этот период легче заметить со стороны. Следует обращать особое внимание на факторы, способствующие развитию этого явления, так как данный синдром легче предупредить, чем лечить.

Среди факторов, вызывающих синдром профессионального выгорания, выделяют группы организационных факторов, а также индивидуальные характеристики самих профессионалов, рассмотрим их более подробно. К группе организационных факторов относят следующие:

1) неопределенность или недостаток ответственности. Если учитель самостоятелен и независим в своей деятельности, у него имеется возможность принимать важные решения, то угроза профессионального выгорания уменьшается;

2) появлению синдрома профессионального выгорания педагогов способствует многочасовой график работы, имеющей трудноизмеримое содержание, требующей исключительной продуктивности или соответствующей подготовки; важным моментом является недооценка руководством качества труда учителя;

3) повышенные нагрузки, сверхурочная работа учителя стимулируют развитие синдрома профессионального выгорания; следует отметить, что перерывы в работе оказывает положительный эффект и снижают уровень выгорания, но этот эффект носит временный характер (уровень профессионального выгорания частично повышается через три дня после возвращения к работе и полностью восстанавливается через три недели от начала профессиональной деятельности) $[1,2,6]$;

4) социальная поддержка со стороны коллег, руководителей, членов семьи, окружающих людей играет решающую роль в предотвращении синдрома профессионального выгорания у педагога, моделируя определённым образом так называемую обратную связь.

Среди индивидуальных характеристик самих профессионалов, вносящих определённый вклад в появление синдрома профессионального выгорания, можно отметить возраст (склонность более молодых по возрасту к выгоранию объясняется наличием эмоционального напряжения, сопровождаемого реальную действительность, часто не соответствуюшую их ожиданиям; семейное положение (более высокая степень предрасположенности к выгоранию отмечается у лиц преимущественно мужского пола, не состоящих в браке). Личностные особенности педагога также играют большую роль в возникновении синдрома профессионального выгорания.

Считается, что личностная выносливость (способность личности осуществлять контроль за жизненными ситуациями и гибко реагировать на различного рода изменения в окружающей действительности) тесно 
связана со всеми тремя компонентами профессионального выгорания. Учителя, имеющие высокий уровень личностной выносливости, имеют низкий уровень профессионального выгорания. Кроме того, педагоги, владеющие активной тактикой сопротивления эмоциональному стрессу, как правило, имеют низкий уровень профессионального выгорания. Среди других характеристик личностных особенностей педагога наиболее тесные связи с профессиональным выгоранием имеет тревожность.

Выявлена тесная связь между синдромом профессионального выгорания и »локусом контроля» человека. При наличии внутреннего локуса контроля человек большей частью принимает ответственность за события, происходящие в его жизни, на себя, объясняя их своим поведением, характером, имеющимися способностями. При преобладании внешнего локуса контроля человек имеет склонность приписывать ответственность за все происходящее внешним факторам, находя причины в других людях, в окружающей среде и т. п. Отмечается положительная корреляционная связь между внешним локусом контроля и составляющими профессионального выгорания [1, 2, 6, 7].

Склонность к синдрому профессионального выгорания в большей степени выражена у людей, реагирующих на стресс по типу А. Люди данного типа реагирования предпочитают бурный темп жизни, любят преодоление трудностей, склонны к конкурентной борьбе, испытывают потребность держать все под личным контролем. В их представлении настоящий специалист - это образец профессиональной неуязвимости и совершенства, в связи с этим они ассоциируют свой труд с предназначением, миссией, поэтому у них стирается грань между работой и личной жизнью.

По нашему мнению, синдром профессионального выгорания является реакцией на стрессовые воздействия. По мнению В.В. Бойко, профессиональное выгорание представляет выработанный личностью механизм психологической защиты, включающий полное или частичное исключение эмоций в ответ на избранные психотравмирующие воздействия $[1,3]$.

Рассмотрим основные направления профилактической работы, касающейся профессионального выгорания.

1. Организация профессиональной деятельности. В целях профилактики профессионального выгорания необходимо обеспечить педагогам перспективу профессионального роста, самосовершенствования, рассмотреть возможность материального поощрения, четко распределить обязанности в соответствии с должностными инструкциями. Особое внимание со стороны администрации учебного заведения должно быть направлено на поддержание благоприятной психологической атмосферы в педагогическом коллективе. 
Немаловажную роль в системе профилактики синдрома профессионального выгорания занимает рациональная организация рабочего места и времени педагогов. Речь идёт о создании благоприятных условий во время рабочего дня, об обеспеченности учебно-методическими пособиями и справочными материалами, о высоком уровне технической оснащенности классного кабинета, соответствующего нормам санитарногигиенических требований. Кроме того, в педагогической деятельности важную роль играет рациональная организация труда и отдыха учителей и детей, направленная на поддержание оптимальной умственной работоспособности и восстановление энергетического баланса организма.

2. Коррекция психологического климата в коллективе, направленная на создание психологического комфорта, целостного и продуктивного взаимодействия всех педагогов и сотрудников, атмосферы сотрудничества и взаимоуважения.

3. Индивидуальная работа с педагогами, включающая три основных направления, соответствующие выявленным аспектам профессионального выгорания.

Первое направление индивидуальной работы направлено на развитие креативности у педагогов, т. е. формирование быстроты, гибкости, точности, оригинальности мышления, что значительно расширяет психическую сферу и является мощным фактором развития личности учителя. Для таких педагогов характерна гибкость мыслительных процессов, лабильность нервной системы, способность к активному творчеству, отказ от стереотипов.

Второе направление индивидуальной работы касается нивелирования влияния негативных профессиональных и личностных факторов на профессиональную деятельность учителя. Учитель должен уметь разрешать конфликтные ситуации в классе, находить конструктивные решения, обладать способностью достигать поставленные цели.

Третье направление индивидуальной работы с педагогами должно быть направлено на профилактику стрессовых состояний, возникающих в связи с напряженной деятельностью. У педагогов необходимо формировать навыки саморегуляции, обучать техникам релаксации, формировать навыки контроля собственного физического и психического состояний, что будет способствовать повышению устойчивости к различного рода стрессам.

Следует указать, что система профилактических мероприятий относительно синдрома профессионального выгорания сотрудников в педагогическом коллективе, должна быть комплексной, организационной, направленной на коррекцию нарушений психического состояния 
учителей, улучшение психологического климата в коллективе, оптимизацию труда педагога.

В связи с вышесказанным, на наш взгляд, актуальным является учет типологических особенностей нервной системы учеников при использовании учителем различных приемов и методов обучения. Зная типологические особенности личности учеников, учитель может по отношению к ним использовать приемы, облегчающие их учебную деятельность и взаимодействие. В отношении учеников со слабой нервной системой в профессиональной деятельности учителя полезными могут быть следующие правила:

- не ставить «слабого» в ситуацию неожиданного вопроса и быстрого ответа на него; нужно дать ученику достаточно времени на обдумывание и подготовку ответа;

- в зависимости от поставленного вопроса желательно требовать ответ в письменной форме, а не в устной;

- нельзя давать для усвоения в ограниченный промежуток времени большой, разнообразный, сложный материал; нужно постараться разбить его на части и давать их постепенно по мере усвоения;

- лучше всего не спрашивать новый, только что изложенный на уроке учебный материал, следует отложить опрос на следующее занятие, дав возможность ученику лучше подготовиться дома к ответу;

- путем построения правильной тактики опросов и поощрения нужно формировать у ученика уверенность в своих силах, в своих знаниях;

- следует осторожно оценивать неудачи ученика, ведь он сам к ним относится очень болезненно;

- во время письменного опроса нужно дать время для проверки и исправления написанного;

- следует реже отвлекать и переключать внимание ученика; нужно создавать спокойную, не напряжённую обстановку на уроках.

Учителю следует учитывать и то, что дается легче ученикам со слабой нервной системой:

1) они относительно хорошо справляются с задачами монотонного характера (когда требуется решить большое количество задач одного типа на уроке или выполнить несколько сходных упражнений);

2) они легче действуют по шаблону, по схеме;

3) любят работать обстоятельно, шаг за шагом выполняя задание, поэтому для них благоприятны ситуации, требующие последовательной, планомерной работы; они не отвлекаются, не перескакивают от одного действия к другому, не забегают вперед, а выполняют их в строгой последовательности; 
4) склонны планировать предстоящую деятельность, любят составлять планы в письменной форме; поэтому они успешнее в тех видах деятельности, которые требуют предварительной и тщательной подготовки; за счет этого они могут самостоятельно проникать в более глубокие связи и отношения внутри учебного материала; они глубже и обстоятельнее усваивают учебный материал и поэтому имеют преимущество в ситуациях, где требуется понимание и знание предмета сверх школьной программы;

5) склонны к систематизации знаний, что также обеспечивает им большую глубину усвоения учебного материала;

6) предпочитают при ответе и при усвоении материала использовать внешние опоры, поэтому разнообразные виды наглядного изображения - графики, схемы, рисунки, диаграммы, таблицы - облегчают им учебную деятельность; вследствие этого они имеют преимущество, когда учитель требует наглядного изображения, например, ситуации или условий задачи;

7) склонны к тщательному контролю за выполнением учебных заданий и проверке полученных результатов; если им дают это делать, они допускают меньше ошибок, чем ученики с сильной нервной системой.

Работа с учениками с инертностью нервных процессов требует от учителя соблюдения следующих ограничений:

1) не требовать от них немедленного включения в работу, так как их активность на уроке возрастает постепенно;

2) не очень разнообразить задания, так как некоторым из учеников в таких условиях очень трудно работать;

3) не требовать от ученика быстрого изменения неудачных формулировок, ему необходимо время на обдумывание нового ответа;

4) не настаивать на импровизации ученика: он предпочитает следовать общепринятым стандартом в ответах;

5) не проводить опрос учеников в начале урока;

6) избегать ситуаций, когда требуется быстрый устный ответ на неожиданный вопрос;

7) в момент выполнения задания не отвлекать, не переключать внимание ученика на что-либо другое;

8) не заставлять ученика отвечать на новый, только что пройденный материал, опрос следует отложить на более позднее время.

При этом учителю следует иметь в виду, что ученики с инертностью нервных процессов могут работать относительно долго, не отвлекаясь на посторонние реплики; успешно выполняют монотонные виды работ 
в течение достаточного количества времени; полностью выслушивают объяснения учителя и только после этого начинают выполнять задание; склонны к самостоятельному выполнению заданий; активны в работе по пройденному материалу, так как у них лучше развита долговременная память, чем кратковременная; легче выполняют самостоятельную работу, чем фронтальную.

Следует помнить, что ученики с сильной и подвижной нервной системой в определенных ситуациях могут иметь свои трудности в обучении. Чтобы принять их во внимание, учителю следует помнить, что недостатки лиц со слабой и инертной нервной системой являются достоинствами лиц с сильной и подвижной нервной системой и наоборот. Поэтому все, что сказано выше об учениках со слабой и инертной нервной системой следует отнести к ученикам с сильной и подвижной нервной системой, но с обратным знаком [6, 8].

При психическом напряжении изменения поведения касаются нарушения процессов научения, проявляются персеверацией, нарушением психомоторной координации. Страдает качество восприятия, сложные формы целенаправленной деятельности, ее планирование и оценка. Роль типа личности в характере ответного поведения при стрессовых условиях существенна. По В.Н. Мясищеву, в экстремальных условиях у импрессивных личностей имеется склонность к заторможенности внешней реакции и усилению вегетативных реакций, к повышению уровня катехоламинов, особенно в значимых ситуациях $[4,5]$. У экспансивных личностей ярко выражены как внешние, так и внутренние (вегетативные) реакции, что соответствует их тенденции к внешнему разряду своих переживаний. У темпераментных, честолюбивых людей в день работы выделение норадреналина в дневное время большее, чем у людей с противоположными чертами характера. В связи с этим приобретает важность индивидуальная оценка ситуаций, вызывающих эмоциональный дискомфорт у человека. Подобная оценка должна быть основана на предыдущем опыте человека, генетической предрасположенности и индивидуальной чувствительности организма.

Итак, процесс обучения во многом провоцирует стресс реакцию для учителя и обучающегося, поэтому учет в процессе реализации стандарта психофизиологических и психологических (личностных) особенностей на наш взгляд будет способствовать создания комфортной психологической атмосферы и сохранению здоровья учителей и обучающихся. 


\section{Библиографический список:}

1. Гнездилов, А.В. Психология и психотерапия потерь / А.В. Гнездилов. - СПб.: Издательство «Речь», 2004. - 162 с.

2. Зборовская, И.В. Саморегуляция психической устойчивости учителя / И.В. Зборовская // Прикладная психология. - 2001. № 6. - С. 55-65.

3. Китаев-Смык, Л.А. Психология стресса. Психологическая антропология стресса / Л.А. Китаев-Смык. - М.: Академический Проект, 2009. - 943 c.

4. Лазаренко, В.В. Роль цитокинов в адаптационных процессах организма студентов к психоэмоциональному стрессу / В.В. Лазаренко, Я.В. Латюшин, В.И. Павлова, Н.В. Мамылина, Ю.Г. Камскова. - Троицк: изд-во ИП Кузнецова Н.Н. - 2010. - 226 с.

5. Мамылина, Н.В. Психофизиологические особенности реакции организма человека на эмоциональное напряжение во время экзамена / Н.В. Мамылина, С.В. Буцык, Ю.Г. Камскова. - Челябинск: изд-во ЧГАКИ. - 2010. - $207 \mathrm{c.}$

6. Орел, В.Е. Феномен «выгорания» в зарубежной психологии: эмпирические исследования и перспективы / В.Е. Орел // Психологический журнал. - 2001. - Т. 22. - № 1. - С. 90-101.

7. Формалюк, Т.В. Синдром «эмоционального сгорания» как показатель профессиональной дезадаптации учителя / Т.В. Формалюк // Вопросы психологии. - 1994. - № 6. - С. 57-64. 


\section{ФОРМИРОВАНИЕ КУЛЬТУРЫ ЗДОРОВОГО И БЕЗОПАСНОГО ОБРАЗА ЖИЗНИ ОБУЧАЮЩИХСЯ}

Н.А. Белоусова

Программа формирования культуры здорового и безопасного образа жизни обучающихся в соответствии с определением Стандарта это комплексная программа формирования их знаний, установок, личностных ориентиров и норм поведения, обеспечивающих сохранение и укрепление физического и психологического здоровья как одного из ценностных составляющих, способствующих познавательному и эмоциональному развитию ребёнка, достижению планируемых результатов освоения основной образовательной программы начального общего образования. В контексте реализации приоритетных национальных проектов «Образование» и »Здоровье» активизировался процесс разработки подходов к созданию и реализации здоровьесберегающих технологий. В частности, в последнее время в школьную практику внедряют комплексные здоровьесберегающие образовательные технологии, целью которых является не только повышение качества самого педагогического процесса, но и сохранение, и укрепление здоровья учащихся (Н.А. Алексеев, 2006; А.А. Плигин, 2007, А.Г. Сухарев, 2012 и др.) [6].

Программа формирования культуры здорового и безопасного образа жизни на ступени начального общего образования сформирована с учётом факторов, оказывающих существенное влияние на состояние здоровья детей:

- неблагоприятные социальные, экономические и экологические условия; В частности, в индустриально развитых районах РФ проблема здоровья населения рассматривается в контексте эволюционно-экологического подхода, в рамках которого определяется какими должны быть оптимальные реакции организма человека на многочисленные факторы среды обитания;

- факторы риска, имеющие место в образовательных учреждениях, которые приводят к дальнейшему ухудшению здоровья детей и подростков от первого к последнему году обучения.

Реакция на конкретные условия существования связана с перераспределением жизненных ресурсов организма между его основными потребностями (ростом, поддержанием жизнедеятельности, репарацией, затратами на учебную или профессиональную деятельность и др.). Любой внешний стимул (в том числе и учебная нагрузка) должен быть 
достаточным, чтобы повышать активность и не превышать по силе, интенсивности и длительности адаптационно-компенсаторные возможности организма, которые характеризуют «цену адаптации».

Чувствительность к воздействиям при одновременной к ним инертности по своей природе, обусловливающей временной разрыв между воздействием и результатом, который может быть значительным, достигая нескольких лет, и тем самым между начальным и существенным проявлением неблагополучных популяционных сдвигов в здоровье детей и подростков и всего населения страны в целом.

Проблема индивидуального здоровья в условиях резкого изменения социально-психологического уклада, нарастающего экологического напряжения, модернизации системы образования является одной из самых сложных и актуальных и не может рассматриваться изолировано от общих проблем человечества.

В современных популяциях людей формируются новые гено-фенотипические варианты свойств человека - морфотипы, которые формировались в соответствии с теми или иными географическими и социальными условиями. Ритмы жизни, урбанизация, миграция, в целом современные экологические изменения, предъявляют к людям новые требования. Более адаптивны генофенотипические свойства людей, которые наиболее адекватно удовлетворяют современным психофизиологическим, социальным, экологическим потребностям жизни. Морфоанатомические преимущества (свойства) все более лишаются своего первостепенного значения. Наоборот: функциональные и психофизиологические свойства (скорость реакции, ритмичность, толерантность и т. д.) становятся ведущими в механизмах адаптации в условиях современной среды обитания.

Приспособительные (или адаптационные) возможности организма могут рассматриваться как мера здоровья (Баевский, Берсенева, 1997) [1]. Здоровье человека складывается из трех основных составляющих (Агаджанян, 1997) [1].: физико-химическая, структурно-функциональная, психоэмоциональная.

Современные подходы к оценке «здоровья базируются на основополагающих теоретических представлениях о единстве организма с окружающей его средой (И.М. Сеченов, И.В. Давыдовский). Учение об адаптации, теория гомеостаза, теория функциональных систем и представления биологической кибернетики о системах управления в живом организме являются научно-методической основой современных представлений о здоровье.

Наиболее эффективным путём формирования культуры здорового и безопасного образа жизни является направляемая и организуемая взрослыми (учителем, воспитателем, психологом, взрослыми в семье) 
самостоятельная работа, способствующая активной и успешной социализации ребёнка в образовательном учреждении, развивающая способность понимать своё состояние, знать способы и варианты рациональной организации режима дня и двигательной активности, питания, правил личной гигиены.

Однако только знание основ здорового образа жизни не обеспечивает и не гарантирует их использования, если это не становится необходимым условием ежедневной жизни ребёнка в семье и образовательном учреждении.

Разработка программы формирования культуры здорового и безопасного образа жизни, а также организация всей работы по её реализации должна строиться на основе научной обоснованности, последовательности, возрастной и социокультурной адекватности, информационной безопасности и практической целесообразности.

Таким образом, одной из важнейших детерминант здоровья принято считать окружающую среду и условия жизни населения.

Сегодня в мировых классификаторах насчитывается около 10 тыс. форм болезней, причем более $80 \%$ из них является следствием экологического напряжения.

Не случайно, что в наши дни именно человек стал предметом глубоких экологических исследований. В результате социального и научнотехнического прогресса природа преобразуется настолько быстро, что встает вопрос о соизмеримости ее изменения с эволюционно обусловленными адаптационными возможностями человека.

Созданная человеком среда обитания теперь воздействует на его собственный организм, на биологические и социальные процессы, вызывая изменения: структуры заболеваемости и смертности, параметров воспроизводства и миграции населения, а также такого интегрального показателя, как продолжительность жизни.

Специально следует отметить развитие концепции саногенеза (Павленко, 1980). Саногенез рассматривается как динамическая система защитно-приспособительных механизмов, возникающая на стадии предболезни, развивающаяся на протяжении всего периода болезни и направленная на восстановление механизмов саморегуляции. В данном случае речь идет о механизмах мобилизации функциональных резервов организма, которые обеспечивают формирование новых функциональных систем, обеспечивающих защиту и развитие компенсаторно-приспособительных процессов.

Несмотря на увеличение потока информации (а иногда вопреки ему), наблюдается низкий уровень знаний о здоровье, о здоровом образе жизни, о методах самозащиты и самокоррекции. 
В связи с выше изложенным широкое распространение в образовательных учреждениях должны получить здоровьесберегающие технологии.

Технология в любой сфере - это деятельность, в максимальной мере отражающая объективные законы данной предметной сферы, построенная в соответствии с логикой развития этой сферы и потому обеспечивающая наибольшее для данных условий соответствие результата деятельности предварительно поставленным целям. Здоровьесберегающая педагогическая деятельность по-новому выстраивает отношения между образованием и воспитанием, переводит воспитание в рамки человекообразующего и жизнеобеспечивающего процесса, направленного на сохранение и приумножение здоровья ребенка или подростка. Здоровьесберегающие педагогические технологии должны обеспечить развитие природных способностей человека: интеллекта, нравственных и эстетических чувств, потребности в деятельности, овладении первоначальным опытом общения с людьми, природой, искусством.

Здоровьесберегающие технологии предполагают активное участие самого обучающегося в освоении культуры человеческих отношений, в формировании опыта здоровьесбережения, который приобретается через постепенное расширение сферы общения и деятельности учащегося, развитие его саморегуляции (от внешнего контроля к внутреннему самоконтролю), становление самосознания и активной жизненной позиции на основе воспитания и самовоспитания, формирования ответственности за свое здоровье, жизнь и здоровье других людей (Е.П. Ильин, 1998) [4].

Здоровьесберегающая технология - это:

- условия обучения в школе (отсутствие стресса, адекватность требований, адекватность методик обучения и воспитания);

- рациональная организация учебного процесса (в соответствии с возрастными, половыми, индивидуальными особенностями и гигиеническими требованиями);

- соответствие учебной и физической нагрузки возрастным возможностям ребенка или подростка;

- необходимый, достаточный и рационально организованный двигательный режим (Л.П. Вашлаева, Т.С. Панина, 2002) [3].

Данные принципы и подходы отражены в образовательном стандарте.

Программа формирования культуры здорового и безопасного образа жизни ставит перед участниками образовательного процесса следующие задачи:

- сформировать представление о позитивных и негативных фактоpax, влияющих на здоровье, в том числе о влиянии на здоровье позитивных и негативных эмоций, получаемых от общения с компьютером, просмотра телепередач, участия в азартных играх; 
- дать представление с учётом принципа информационной безопасности о негативных факторах риска здоровью детей (сниженная двигательная активность, инфекционные заболевания, переутомления и т. п.), о существовании и причинах возникновения зависимостей от табака, алкоголя, наркотиков и других психоактивных веществ, их пагубном влиянии на здоровье;

- сформировать представление об основных компонентах культуры здоровья и здорового образа жизни:

- научить выполнять правила личной гигиены и развить готовность на основе их использования самостоятельно поддерживать своё здоровье;

- сформировать представление о правильном (здоровом) питании, его режиме, структуре, полезных продуктах;

- сформировать представление о рациональной организации режима дня, учёбы и отдыха, двигательной активности, научить ребёнка составлять, анализировать и контролировать свой режим дня;

- обучить элементарным навыкам эмоциональной разгрузки (релаксации);

- сформировать навыки позитивного коммуникативного общения;

- научить обучающихся делать осознанный выбор поступков, поведения, позволяющих сохранять и укреплять здоровье;

- сформировать потребность ребёнка безбоязненно обращаться к врачу по любым вопросам состояния здоровья, в том числе связанным с особенностями роста и развития.

Система имеет ниже названные составляющие.

1. Использование данных мониторинга состояния здоровья учащихся, проводимого медицинскими работниками, и собственных наблюдений в процессе реализации образовательной технологии, ее коррекция в соответствии с имеющимися данными.

2. Учет особенностей возрастного развития школьников и разработка образовательной стратегии, соответствующей особенностям памяти, мышления, работоспособности, активности и т. д. учащихся данной возрастной группы.

3. Создание благоприятного эмоционально-психологического климата в процессе реализации технологии.

4. Использование разнообразных видов здоровьесберегающей деятельности учащихся, направленных на сохранение и повышение резервов здоровья, работоспособности (А.Т. Тутатчиков, 2006).

Цель педагогической (образовательной) технологии - достижение заданного образовательного результата в обучении, воспитании, развитии. 
Классификация здоровьесберегающих технологий осуществляется по ряду признаков, например по характеру действия они разделяются на 4 группы:

1. Защитно-профилактические технологии. Направлены на защиту человека от неблагоприятных для здоровья воздействий. К таким технологиям относятся: выполнение санитарно-гигиенических требований, регламентированных СанПиНами; поддержание чистоты и проведение прививок с целью предупреждения инфекций; ограничение предельного уровня учебной нагрузки, исключающего наступление состояния переутомления учащихся; использование страховочных средств и защитных приспособлений в спортзалах с целью профилактики травматизма и т. п. Большая часть того, что в образовательное учреждениях традиционно понимается под здоровьесберегающими технологиями, как раз и относится к этой группе.

2. Компенсаторно-нейтрализующие технологии. При их использовании ставится задача восполнить недостаток того, что требуется организму для полноценной жизнедеятельности, или хотя бы частично нейтрализовать негативные воздействия в тех случаях, когда полностью защитить человека от них не представляется возможным. Это, например, физкультминутки и физкультпаузы, в какой-то мере нейтрализующие неблагоприятное воздействие статичности уроков, недостаточность физической нагрузки, эмоциональные разрядки, или «минутки покоя», снижающие стрессогенные воздействия, психоэмоциональное напряжение.

3. Стимулирующие технологии. Позволяют активизировать собственные силы организма, использовать его ресурсы для выхода из нежелательного состояния. Типичные примеры - температурное закаливание, физические нагрузки. В психотерапии немало приемов, помогающих вывести пациента из состояния депрессии, уныния, фрустрации.

4. Информационно-обучающие технологии. Обеспечивает учащимся уровень грамотности, необходимый для эффективной заботы о здоровье - своем и своих близких, помогают и воспитании культуры здоровья. К таким технологиям относятся образовательные, просветительские и воспитательные программы, адресованные учащимся, их родителям и педагогам (Шибкова Д.3., 1998-2001, В.Ф. Черник, 2004) [5,7].

По организационным особенностям здоровьесберегающие приемы и методы, используемые в образовательных учреждениях, подразделяются на обеспечивающие и реконструирующие. Первые создают необходимые условия проведения образовательного процесса и по большей части регламентированы в СанПиНах. Вторые нацелены на привнесение новых элементов, условий, не предусмотренных нормативными документами. Например, создание в образовательном учреждении фитобара, 
кабинета физиотерапии, цветовой подсветки в классах, аудиосопровождения уроков, оздоровительно-психологических тренингов для учащихся и педагогов и т. д.

Основную группу технологий здоровьесберегающей педагогики составляют образовательные здоровьесберегающие технологии, которые подразделяются на три подгруппы:

- организационно-педагогические технологии (ОПТ), определяющие структуру учебного процесса, частично регламентированную в СанПиНах, способствующую предотвращению переутомления, гиподинамии и других дезадаптационных состояний;

- психолого-педагогические технологии (ППТ), связанные с непосредственной работой педагога на уроке. Сюда же относится и психолого-педагогическое сопровождение всех элементов образовательного процесса;

- учебно-воспитательные технологии (УВТ), включающие программы по обучению грамотной заботе о своем здоровье и формированию культуры здоровья учащихся, мотивации их к падению здорового образа жизни, предупреждению вредных и привычек, предусматривающие также проведение организационно-воспитательной работы после уроков [2].

Отдельное место занимают еще две группы технологий, традиционно реализуемых вне учреждения профессионального образования, но в последнее время все чаще включаемых во внеурочную работу учреждения профессионального образования:

- социально адаптирующие и личностно развивающие технологии (САЛРТ) включают технологии, обеспечивающие укрепление психологического здоровья учащихся, повышение ресурсов психологической адаптации личности. Сюда относятся разнообразные социально-психологические тренинги, программы социальной и семейной педагогики, к участию в которых целесообразно привлекать не только учащихся, но и их родителей, а также педагогов;

- лечебно-оздоровительные технологии (ЛОТ) составляют самостоятельные медико-педагогические области знаний: лечебную педагогику и лечебную физкультуру, воздействие которых обеспечивает восстановление физического здоровья учащихся.

Согласно образовательному стандарту организация работы образовательного учреждения по формированию у обучающихся культуры здорового образа жизни осуществляется в два этапа.

Первый этап - анализ состояния и планирование работы образовательного учреждения по данному направлению, в том числе по:

- организации режима дня детей, их нагрузкам, питанию, физкультурно-оздоровительной работе, сформированности элементарных 
навыков гигиены, рационального питания и профилактике вредных привычек;

- организации просветительской работы образовательного учреждения с учащимися и родителями (законными представителями);

- выделению приоритетов в работе образовательного учреждения с учётом результатов проведённого анализа, а также возрастных особенностей обучающихся на ступени начального общего образования.

Bmopoй эman - организация работы образовательного учреждения по данному направлению.

1. Просветительско-воспитательная работа с обучающимися, направленная на формирование ценности здоровья и здорового образа жизни, включает:

- внедрение в систему работы образовательного учреждения дополнительных образовательных программ, направленных на формирование ценности здоровья и здорового образа жизни, которые должны носить модульный характер, реализовываться во внеурочной деятельности либо включаться в учебный процесс;

- лекции, беседы, консультации по проблемам сохранения и укрепления здоровья, профилактике вредных привычек;

- проведение дней здоровья, конкурсов, праздников и других активных мероприятий, направленных на пропаганду здорового образа жизни;

- создание в школе общественного совета по здоровью, включающего представителей администрации, учащихся старших классов, родителей (законных представителей), преставителей детских физкультурнооздоровительных клубов.

2. Просветительская и методическая работа с педагогами, специалистами и родителями (законными представителями), направленная на повышение квалификации работников образовательного учреждения и повышение уровня знаний родителей (законных представителей) по проблемам охраны и укрепления здоровья детей, включает:

- проведение соответствующих лекций, семинаров, круглых столов и т. п.;

- приобретение для педагогов, специалистов и родителей (законных представителей) необходимой научно-методической литературы;

- привлечение педагогов, медицинских работников, психологов и родителей (законных представителей) к совместной работе по проведению оздоровительных мероприятий и спортивных соревнований.

Системная работа на ступени начального общего образования по формированию культуры здорового и безопасного образа жизни может быть представлена в виде пяти взаимосвязанных блоков: 


\begin{tabular}{|c|c|}
\hline $\begin{array}{c}\text { Составляющие деятель- } \\
\text { ности образовательного } \\
\text { учреждения по формиро- } \\
\text { ванию культуры здорового } \\
\text { и безопасного образа жизни }\end{array}$ & Содержание деятельности \\
\hline $\begin{array}{l}\text { Здоровьесберегающая ин- } \\
\text { фраструктура образователь- } \\
\text { ного учреждения }\end{array}$ & $\begin{array}{l}\text { • соответствие состояния и содержания здания } \\
\text { и помещений образовательного учреждения } \\
\text { санитарным и гигиеническим нормам, нормам } \\
\text { пожарной безопасности, требованиям охраны } \\
\text { здоровья и охраны труда обучающихся; } \\
\text { • наличие и необходимое оснащение помещений } \\
\text { для питания обучающихся, а также для хранения } \\
\text { и приготовления пищи; } \\
\text { • организацию качественного горячего питания } \\
\text { учащихся, в том числе горячих завтраков; } \\
\text { • оснащённость кабинетов, физкультурного зала, } \\
\text { спортплощадок необходимым игровым и спор- } \\
\text { тивным оборудованием и инвентарём; } \\
\text { • наличие помещений для медицинского персонала; } \\
\text { • наличие необходимого (в расчёте на количество } \\
\text { обучающихся) и квалифицированного состава спе- } \\
\text { циалистов, обеспечивающих оздоровительную рабо- } \\
\text { ту с обучающимися (логопеды, учителя физической } \\
\text { культуры, психологи, медицинские работники). }\end{array}$ \\
\hline $\begin{array}{l}\text { Рациональная организа- } \\
\text { ция учебной и внеучебной } \\
\text { деятельности обучающихся, } \\
\text { направленная на повышение } \\
\text { эффективности учебного } \\
\text { процесса, снижение при этом } \\
\text { чрезмерного функционального } \\
\text { напряжения и утомления, } \\
\text { создание условий для снятия } \\
\text { перегрузки, нормального чере- } \\
\text { дования труда и отдыха }\end{array}$ & $\begin{array}{l}\text { • соблюдение гигиенических норм и требований } \\
\text { к организации и объёму учебной и внеучебной } \\
\text { нагрузки (выполнение домашних заданий, заня- } \\
\text { тия в кружках и спортивных секциях) учащихся } \\
\text { на всех этапах обучения; } \\
\text { • использование методов и методик обучения, } \\
\text { адекватных возрастным возможностям и особен- } \\
\text { ностям обучающихся (использование методик, } \\
\text { прошедших апробацию); } \\
\text { • введение любых инноваций в учебный процесс } \\
\text { только под контролем специалистов; } \\
\text { • строгое соблюдение всех требований к исполь- } \\
\text { зованию технических средств обучения, в том } \\
\text { числе компьютеров и аудиовизуальных средств; } \\
\text { • индивидуализация обучения (учёт индивиду- } \\
\text { альных особенностей развития: темпа развития } \\
\text { и темпа деятельности), работа по индивидуальным } \\
\text { программам начального общего образования; } \\
\text { • ведение систематической работы с детьми } \\
\text { с ослабленным здоровьем и детьми с ограничен- } \\
\text { ными возможностями здоровья, посещающими } \\
\text { специальные медицинские группы под строгим } \\
\text { контролем медицинских работников. }\end{array}$ \\
\hline
\end{tabular}




\begin{tabular}{|c|c|}
\hline $\begin{array}{c}\text { Составляющие деятель- } \\
\text { ности образовательного } \\
\text { учреждения по формиро- } \\
\text { ванию культуры здорового } \\
\text { и безопасного образа жизни }\end{array}$ & Содержание деятельности \\
\hline $\begin{array}{l}\text { Эффективная организация } \\
\text { физкультурно-оздорови- } \\
\text { тельной работы, направ- } \\
\text { ленная на обеспечение } \\
\text { рациональной организации } \\
\text { двигательного режима } \\
\text { обучающихся, нормально- } \\
\text { го физического развития } \\
\text { и двигательной подготов- } \\
\text { ленности обучающихся } \\
\text { всех возрастов, повышение } \\
\text { адаптивных возможностей } \\
\text { организма, сохранение } \\
\text { и укрепление здоровья об- } \\
\text { учающихся и формирование } \\
\text { культуры здоровья }\end{array}$ & $\begin{array}{l}\text { • полноценную и эффективную работу с обучаю- } \\
\text { щимися всех групп здоровья (на уроках физкуль- } \\
\text { туры, в секциях и т. п.); } \\
\text { • рациональную и соответствующую органи- } \\
\text { зацию уроков физической культуры и занятий } \\
\text { активно-двигательного характера на ступени } \\
\text { начального общего образования; } \\
\text { • организацию занятий по лечебной физкультуре; } \\
\text { • организацию часа активных движений (дина- } \\
\text { мической паузы) между 3-м и 4-м уроками; } \\
\text { • организацию динамических перемен, физкульт- } \\
\text { минуток на уроках, способствующих эмоцио- } \\
\text { нальной разгрузке и повышению двигательной } \\
\text { активности; } \\
\text { • организацию работы спортивных секций и соз- } \\
\text { дание условий для их эффективного функциони- } \\
\text { рования; } \\
\text { • регулярное проведение спортивно-оздорови- } \\
\text { тельных мероприятий (дней спорта, соревнова- } \\
\text { ний, олимпиад, походов и т. п.). }\end{array}$ \\
\hline $\begin{array}{l}\text { Реализация дополнитель- } \\
\text { ных образовательных про- } \\
\text { грамм }\end{array}$ & $\begin{array}{l}\text { • внедрение в систему работы образовательного уч- } \\
\text { реждения программ, направленных на формирова- } \\
\text { ние ценности здоровья и здорового образа жизни, } \\
\text { в качестве отдельных образовательных модулей или } \\
\text { компонентов, включённых в учебный процесс; } \\
\text { • проведение дней здоровья, конкурсов, празд- } \\
\text { ников и т. п.; } \\
\text { • создание общественного совета по здоровью, } \\
\text { включающего представителей администрации, } \\
\text { учащихся старших классов, родителей (закон- } \\
\text { ных представителей), разрабатывающих и реа- } \\
\text { лизующих школьную программу «Образование } \\
\text { и здоровье». } \\
\text { Программы, направленные на формирование цен- } \\
\text { ности здоровья и здорового образа жизни, пред- } \\
\text { усматривают разные формы организации занятий: } \\
\text { • интеграцию в базовые образовательные дис- } \\
\text { циплины; } \\
\text { • проведение часов здоровья; }\end{array}$ \\
\hline
\end{tabular}




\begin{tabular}{|c|c|}
\hline $\begin{array}{c}\text { Составляющие деятель- } \\
\text { ности образовательного } \\
\text { учреждения по формиро- } \\
\text { ванию культуры здорового } \\
\text { и безопасного образа жизни }\end{array}$ & Содержание деятельности \\
\hline & $\begin{array}{l}\text { • факультативные занятия; } \\
\text { - занятия в кружках; } \\
\text { • проведение досуговых мероприятий: конкур- } \\
\text { сов, праздников, викторин, экскурсий и т. п.; } \\
\text { • организацию дней здоровья. }\end{array}$ \\
\hline $\begin{array}{l}\text { Просветительская работа } \\
\text { с родителями (законными } \\
\text { представителями) }\end{array}$ & $\begin{array}{l}\text { • лекции, семинары, консультации, курсы по } \\
\text { различным вопросам роста и развития ребёнка, } \\
\text { его здоровья, факторам, положительно и отрица- } \\
\text { тельно влияющим на здоровье детей и т. п.; } \\
\text { • приобретение для родителей (законных пред- } \\
\text { ставителей) необходимой научно-методической } \\
\text { литературы; } \\
\text { • организацию совместной работы педагогов } \\
\text { и родителей (законных представителей) по } \\
\text { проведению спортивных соревнований, дней } \\
\text { здоровья, занятий по профилактике вредных } \\
\text { привычек и т. п. }\end{array}$ \\
\hline
\end{tabular}

Результат совокупного воздействия на учащихся всех здоровьесберегающих технологий должен оцениваться с помощью комплекса методов медико-психолого-педагогической диагностики, мониторинга. Постоянное получение обратной связи позволяет своевременно вносить в работу необходимые коррективы (М.П. Дорошкевич, М.А. Нашкевич, Д.М. Муравьева, В.Ф. Черник, 2004) [5].

В рамках биологического подхода к проблеме «здоровье человека» организм рассматривается как многоуровневая система, в которой структурно-функциональные сдвиги за пределы «нормы реакции» на одном из уровней организации компенсируются на других уровнях, благодаря реализации эволюционно закрепленных универсальных механизмов саморегуляции.

У каждой системы организма в любом периоде онтогенеза существует собственная физиологическая норма.

Анализ показателей функционального состояния различных систем организма обследуемого позволяет выявить их отклонение от возрастной динамики изменений данных показателей, соответствующей популяционному эталону (Б.И. Ткаченко, 2001). 
Реализация инновационных методов обучения, различных вариантов развивающего обучения должна включать такие прогностические формы деятельности, которые позволили бы гармонизировать систему образования с повышением уровня здоровья обучающихся.

Решение такой задачи требует применения адекватных средств контроля и наличия соответствующих критериев оценки функционального состояния организма на разных этапах его развития. На современном этапе развития образования имеющиеся средства и критерии не имеют четко выстроенной системы и находятся в состоянии апробации. Научной школой профессора Д.3. Шибковой внедрено программное обеспечение «Мониторинг физического развития, физической подготовленности и здоровья школьников» [7]. Программа охватывает широкий спектр показателей, но не учитывает психофизиологической и психологической составляющих. Множественность критериев оценки уровня культуры здорового и безопасного образа жизни ставит следующие проблемы:

- многообразий критериев вызывает затруднения в отборе не только более значимых, но и требует установить корреляционные зависимости многообразием показателей;

- возникает вопрос, что использовать в качестве группы критериев - качество освоения содержания, качество применения знаний в повседневной деятельности или совокупность показателей характеризующих функциональное состояние организма.

Проблема обозначена и решение этой проблемы, несомненно, дело ближайшего будущего.

Итак, выводы:

1. При многообразии существующих здоровьесберегающих технологий каждому образовательному учреждению необходимо будет разрабатывать свою технологию, так как в основе работы по формированию культуры здорового и безопасного образа жизни лежит характеристика популяции обучающихся, а также возможности конкретной окружающей и образовательной среды [2].

2. От выше названных условий будет зависеть и содержание программы мониторинга уровня сформированности культуры здорового и безопасного образа жизни.

\section{Библиографический список:}

1. Агаджанян Н.А. Проблемы адаптации и учение о здоровье / Н.А. Агаджанян, Р.М. Баевский, А.П. Берсенева. - М.: Изд-во РУДН, 2006. -284 c. 
2. Белоусова Н.А. Программа комплексной коррекции нарушений осанки у подростков в условиях образовательного учреждения: научнометодическое пособие/ Н.А. Белоусова, Д.З. Шибкова. - Челябинск: Полиграф-Мастер, 2013.-159 с.

3. Вашлаева Л.П., Панина Т.С. Здоровьесберегающее образование: теорет. и приклад. аспекты: сб. ст./ Перм. гос. пед. ун-т. - Пермь: Кн. мир; Звезда, 2002. - 205 с.

4. Ильин Е.П. Психофизиология состояний человека. - СанктПитербург, 2005. - 412 с.

5. Основы валеологии и школьной гигиены :учеб.пособие для вузов / авт. Дорошкевич М.П., Нашкевич М.А., Муравьева Д.М., Черник В.Ф.Минск: Высш.шк., 2004. - 238 с.: ил.

6. Сухарев А.Г. Образовательная среда и здоровье учащихся. Научнометодическое пособие. М.: МИОО, 2012- 256 с.

7. Шибкова Д.3. Организация здоровьесберегающей среды с использованием автоматизированной программы «Мониторинг здоровья»: монография / Д.3. Шибкова, П.А. Байгужин. - Челябинск: Изд-во Челяб. гос. пед. ун-та, 2001.-165 с. 


\section{ГАава 3. ПОВЫШЕНИЕ ПРОФЕССИОНАЯЬНОЙ КОМПЕТЕНТНОСТИ УЧИТЕЯЕЙ НАЧАЛЬНЫХ КЛАССОВ В УСЛОВИЯХ РЕАЛИЗАЦИИ ФГОС НОО}

М.А. Худякова

\section{1. Понятие компетентности как интегрального свойства личности. Профессиональная компетентность педагога}

Во всех исследованиях по проблемам интеллекта компетентность понимается как одно из свойств, в котором объединяются, интегрируются другие свойства интеллекта. М.А. Холодная под интеллектуальной компетентностью понимает особый тип организации знаний, обеспечивающий возможность принятия эффективных решений в определенной предметной области деятельности и выдвигает требования к подобного рода знаниям в виде разнообразия; артикулированности; гибкости; быстроты актуализации в данный момент в нужной ситуации; возможности применения в широком спектре ситуаций; выделенности ключевых элементов; категориальности; владения декларативным и процедурным знаниями; наличия знания о собственном знании.

Такой подход, достаточный для исследований по психологии и направленный на выявление психических свойств личности, недостаточен для исследований по педагогике, выявляющих условия успешности обучения и воспитания индивида. К этому надо добавить, что другие исследователи компетентности отмечают ее новые стороны. Так, Дж. Равен замечает: «Основанное на ценностях понимание социальных процессов играет центральную роль в компетентном поведении и должно учитываться при любой осмысленной оценке компетентности. Основным источником некомпетентного профессионального поведения в современном обществе оказывается неспособность и нежелание людей предпринимать что бы то ни было в отношении многочисленных социальных, организационных и политических ограничений, находящихся за пределами их прямых служебных обязанностей» [18, с. 69]. 
Концепция педагогической категории «компетентность»

На наш взгляд, структура компетентности определяется ее функциями. Мы проведем анализ этой структуры по схеме:

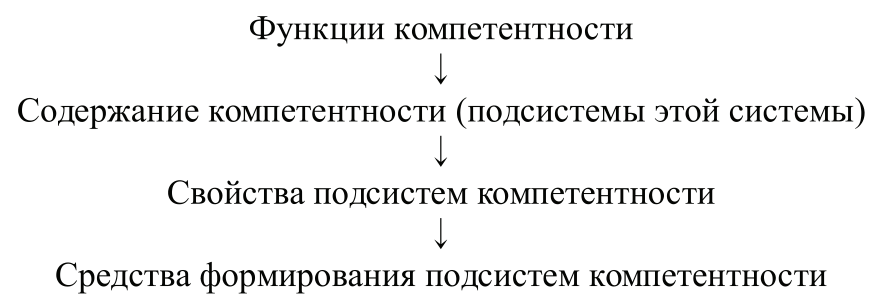

1. Первая группа функций компетентности - гносеологические функции - функции, направленные на адекватное восприятие, осмысление природных и социальных процессов действительного мира: отражение, познание, моделирование мира.

Познание - высшая форма отражения объективной действительности. Индивид познает мир, овладевая коллективно выработанной, объективированной системой знаний, передаваемых от одного поколения к другому. Различают чувственное и логическое познание.

Чувственное познание выступает в форме образов, которые возникают в сознании человека в результате ощущения, восприятия, представления. Сущность данных познавательных действий заключается в том, что учащиеся с помощью органов чувств (слуха, зрения, осязания и обоняния) воспринимают внешние свойства, особенности, признаки изучаемых предметов и явлений. Результат этого восприятия состоит в формировании представлений как низшей формы знаний, так как в сознании человека сохраняются лишь внешние образы (признаки, свойства) воспринимаемых предметов и явлений и не раскрывается их сущность. В то же время чувственное познание - необходимое условие и основание любого осознания. Благодаря чувственному познанию реальности внешнего объективного мира становятся элементом внутреннего мира познающего субъекта, преобразуются сознанием и осваиваются им. Это первая стадия отражения материального мира в духовном, идеальном. Но именно на этом пути и возникает гносеологическое противопоставление материи и сознания. Сознание выступает здесь как некое устройство, с помощью которого субъект отражает действительность.

Формами логического познания являются понятия, суждения, умозаключения. Понятие невозможно без такого познавательного действия, как осмысление, в результате которого раскрывается сущность изучаемых 
предметов и явлений, и формируются научные понятия. Процесс осмысления включает в себя такие мыслительные действия, как анализ воспринимаемых внешних свойств и признаков изучаемых предметов и явлений; их логическую группировку, выделение свойств наиболее существенных и общих для всех подобного рода предметов и явлений; мысленное постижение причинно-следственных связей и формирование теоретических понятий или обобщающих выводов; проверку обоснованности и истинности сделанных выводов. Исследованиями в области педагогики установлено, что учащиеся гораздо труднее выделяют общие признаки предметов и явлений, нежели их различия. Результатом осмысления является понимание изучаемого материала и образование понятий как формы научного знания, в которой раскрывается сущность познаваемых предметов и явлений и которая выражается в виде законов, правил, выводов и других теоретических обобщений.

Логическое познание основано на том, что человек создает в своем сознании модель мира, отбрасывая тысячи свойств предмета, несущественных для данного исследования и наделяя предмет несуществующими идеальными свойствами. Таким образом, создание модели связано с определенным отбором содержания, который, конечно, зависит от субъективных качеств познающей личности. Гносеологическая модель носит комплексный характер, в ее создании участвует и чувственная сторона познания. Моделирование осуществляет пусть и искаженное, но целостное отражение действительности, оно обладает пространственной и временной определенностью, выполняет функцию идентификации предмета, включает в класс подобных предметов, осуществляет связь с другими классами и позволяет выявлять и формулировать закономерности отражаемого предмета, явления. Можно сказать, что моделирование объединяет чувственное и логическое познание, создавая образ предмета, который, конечно, не может быть идентичен предмету. По замечанию А. Пуанкаре, это «значило бы заставить целое войти в состав части» [16, с. 288].

Названные функции компетентности определяют ее первую структуру (подсистему) - систему знаний. Под системой понимают множество связанных между собой элементов, представляющих собой определенное целостное образование и характеризующееся такими качествами, как гибкость, динамичность, вариативность, адаптивность, стабильность, прогностичность, преемственность, целостность.

Говоря о сущности знания, следует иметь ввиду, что с одной стороны, оно обозначает результат научного познания, а с другой - выступает как предмет усвоения. По словам философа П.В. Копнина, знание - это 
совокупность идей человека, в которых выражено теоретическое овладение им предметом. В результате учебного познания учащиеся должны овладеть изучаемыми предметами. Но овладение - это не открытие новых теоретических идей, а познание того, что уже есть в науке, что нужно понять, сохранить в памяти, уметь воспроизводить и применять на практике.

В «Новейшем философском словаре» [12] выделяются следующие типы знаний (по уровню их функционирования):

- обыденное знание повседневной жизни;

- специализированное знание (научное, религиозное, философское и т. д.);

- практическое знание («предметное» - направленное на объекты, процессы, явления);

- метазнание - знание о знании и возможностях работы со знанием.

Знания нужны человеку для жизненной практики и духовного развития. В.В. Маланин и И.С. Утробин пишут, что «ценность знания, определяемая, в первую очередь, резко возрастающей сложностью труда, и само знание приобретает статус одного из решающих факторов развития общества на пороге третьего тысячелетия» [10, с. 20].

Владение методом научного познания означает уменье применять его к решению разнообразных вопросов, способность приходить самому к новому знанию, а также расширять сферу знания самостоятельными исследованиями.

Система знаний компетентного человека характеризуется следующими качествами:

- адекватность отражения, предполагающая соответствие между явлениями окружающего мира, процессами их переработки в мозгу и тем, что представлено в психических образованиях индивида;

- понимание мира (постижение его целостности и законов природы);

- отражение действительности сознанием выступает как форма ее моделирования;

- предицирование (снятие неопределенности, направление на понимание сути предмета, создание его образа);

- широта, определяемая множеством разных знаний о разном - разнообразием; энциклопедичностью знаний; кругозором.

- глубина (содержательность, уровень постижения истины, значительность проникновения в нее);

- системность, включающая полноту, целостность знания; осознание учащимися закономерных устойчивых связей; их иерархии (Л.Я. Зорина [8, с. 31] считает, что для достижения системности знаний «необходимо в содержание образования по основам наук, кроме предметных 
знаний, включать еще и специальные методологические знания»; такого же мнения придерживается и М.Н. Скаткин [7]);

- антропоморфизм (характерное для европейской культуры понимание организации действительного мира через соизмеримость с человеком, который мыслит себя в единстве с миром, т. е. человеческое содержание порядка мира; познание человеком самого себя);

- обобщенность, категориальность знания, т. е. знание, представленное в виде общих принципов, общих подходов, общих идей;

- диалектичность - отражение явлений действительности в их взаимосвязях и развитии; способность отражать противоречия действительности.

Эти качества знания формируются в процессе образования. Под образованием понимается результат обучения, т. е. совокупность систематизированных знаний, умений и навыков, взглядов и убеждений, а также определенный уровень развития познавательных сил, практической подготовки, достигнутый в результате учебно-воспитательной работы.

Умственное воспитание заключается в овладении учащимися знанием основ наук о природе, обществе, человеческом мышлении, в формировании на базе этого знания основ диалектико-материалистического мировоззрения, в развитии познавательных сил учащихся. Общее образование обеспечивает учащимся понимание закономерностей развития предметов и явлений объективного мира и вооружает простейшими навыками применения знаний на практике. Образование - это процесс движения от целей к результату, процесс взаимодействия педагогов с учащимися, когда те, участвуя в процессе обучения и учения, воспитания и самовоспитания, развития и саморазвития, становятся субъектом педагогической взаимодеятельности.

«Реальный интеллектуальный потенциал ребенка можно оценить только после включения двух факторов - обучения и учения» [23, с. 230]. На основе этой общей задачи М.А. Холодная предлагает свою систему обучения по «обогащающей модели», направленного на развитие индивидуального ментального опыта, на формирование соответствующих психических структур. Ее основные положения:

- каждый ребенок является носителем ментального опыта;

- адресатом педагогического воздействия является особенности состава и строения индивидуального ментального опыта;

- механизмы интеллектуального развития личности связаны с процессами, идущими в пространстве индивидуального ментального опыта и характеризующими его перестройку и обогащение, следствием чего является рост индивидуальных интеллектуальных способностей; 
- каждый ребенок имеет свой диапазон возможного наращивания интеллектуальных сил, и задача учителя заключается в оказании ему необходимой помощи средствами индивидуализации учебной и внешкольной деятельности ребенка;

- критерии эффективности учебного процесса, наряду с знаниями, умениями, навыками, связаны с основными показателями уровня интеллектуального развития личности в виде КИТСУ [23, с. 299]. Последняя аббревиатура расшифровывается следующим образом:

К - компетентность - особый тип организации знаний, обеспечивающий возможность принятия эффективных решений.

И - инициатива - желание самостоятельно отыскивать новую информацию, выдвигать идеи, осваивать новые области деятельности.

Т - творчество - процесс создания субъективно нового, способность порождать оригинальные идеи и использовать нестандартные способы деятельности;

C - саморегуляция - умение произвольно управлять собственной интеллектуальной деятельностью, целенаправленно строить процесс самообучения (школьник сам себя учит);

У - уникальность ума - индивидуально своеобразные способы интеллектуального отношения к происходящему, выраженность индивидуальных познавательных стилей, сформированность индивидуальных интеллектуальных предпочтений; поддерживать уникальность ума обучаемого - высочайший уровень педагогического мастерства.

Обогащающая модель обучения реализована в проекте МПИ (математика, психология, интеллект; руководитель проекта Э.Г. Гельфман) для учащихся 5-9 классов.

Вместе с тем обогащающая модель обучения может быть реализована и на ступени начального общего образования. Если урок будет строиться с учетом положений: ученик - субъект учебной деятельности; разнообразие источников знания; динамичность структуры урока; поддержка инициативы ученика; формулирование целей индивидуальной или коллективной деятельности; критериальное оценивание.

С.Е. Шилов и В.К. Кальнева, обращаясь к проблемам качества образования, считают, что знания и умения представляются как компетенция в действии: «Компетенцию можно рассматривать как возможность установления связи между знанием и ситуацией или, в более широком смысле, как способность найти, обнаружить процедуру (знание и действие), подходящую для проблемы [24, с. 72]. Далее они указывают на то, что компетенция не может быть определена только через определенную сумму знаний и умений, так как «значительная роль в ее проявлении 
принадлежит обстоятельствам. Быть компетентным означает умение мобилизовать в данной ситуации полученные знания и опыт» [там же, с. 81].

Основная задача высшей школы заключается в подготовке квалифицированных специалистов. В.В. Орлов, разрабатывая концепцию образования, говорит: «Одной из важнейших целей университетского образования является развитие интеллектуальных способностей, интеллектуальной культуры личности, от чего коренным образом зависит интеллектуальная культура общества. Интеллектуализация образования обеспечивается фундаментализацией образования, изучением смежных дисциплин, участием в научной работе, изучением дисциплин, направленных на воспитание интеллекта» [15, с. 10].

Но образование можно рассматривать и как результат, который фиксирует факт присвоения личностью ценностей, рождающихся в процессе образовательной деятельности и являющихся значимыми для экономического, нравственного, интеллектуального состояния каждого человека. Б.С. Гершунский [3] в качестве образовательных результатов рассматривает:

- грамотность (гуманитарные, естественнонаучные аспекты первоначального познания мира в их гармонии и взаимодействии);

- образованность - это грамотность, доведенная до общественно и личностно необходимого максимума. Она предполагает наличие достаточно широкого кругозора по самым различным вопросам жизни человека и общества и определенную избирательность по глубине понимания проблем окружающей действительности; образованность характеризует личностные образовательные приобретения;

- профессиональная компетентность, определяющаяся уровнем собственного профессионального образования, опытом, индивидуальными способностями человека, его мотивированным стремлением к непрерывному самообразованию и самосовершенствованию, творческим и ответственным отношением к делу;

- культура - высшее проявление человеческой образованности и профессиональной компетентности;

- менталитет, в котором воплощаются основания мировоззрения и поведения человека.

2. Вторая функция компетентности - аксиологическая (оценочная), позволяющая соотнести отраженную реальность с взглядами, представлениями, убеждениями, идеалами личности и определяющая систему ценностей - систему нравственных и других социальных норм, принципов, идеалов, установок, их функционирование в конкретных исторических условиях.

В структуре компетентности эта функция формирует систему ценностей субъекта, которая характеризует цельность личности, верность 
идеалам, настойчивость в достижении поставленных перед собой целей. Аксиологическая система личности определяется ее общественными отношениями и опирается на систему мировоззренческих взглядов, представлений, убеждений:

- в брачно-семейных отношениях складываются первичные ценности: человек, жизнь, любовь, семья, семейное благополучие;

- производственные отношения расширяют систему ценностей, добавляя такие, как здоровье, работа, творчество, карьера, удовлетворение материальных потребностей;

- в политических отношениях определяются основополагающие ценности: свобода, равенство социальная справедливость, отечество, патриотизм и др.;

- правовые отношения формируют такие ценности, как закон, право, правовое государство;

- религиозные отношения направлены на соблюдение таких ценностей, как любовь к богу, жизнь по заветам бога, религиозная нравственность; с атеизмом сопряжено освобождение человека от влияния религии;

- в гносеологичесих отношениях ценностями являются знания, истина; в философских взглядах отражаются следующие ценности: суть явлений, смысл бытия, предназначение человека, познание мира;

- ценности педагогических отношений: образование, воспитание, развитие, культура;

- коммуникативные отношения отражают общение, дружбу, игру, досуг, развлечения;

- важнейшие ценности складываются в нравственных отношениях: добро, долг, честь, нравственное поведение, совесть, стремление принести пользу людям и др.;

- согласие, гражданский мир, благо нации (этноса) - такие ценности регулируются социально-психологическими отношениями;

- главная ценность эстетических отношений - красота.

Свойства системы ценностей проявляются в том, что в них выражены предельные ориентации знаний, интересов и предпочтений личности. Можно сказать, что ценность выражает способ существования личности и выступает в качестве наиболее высокого уровня социальной регуляции, a ее усвоение отдельной личностью составляет основу социализации этой личности. Выделяют социальные и личностные ценности, взаимопереходы которых определяют взаимодействие личности и общества. Ценности личности образуют систему ее ценностных ориентаций (совокупность важнейших качеств личности, являющихся для нее особо значимыми), составляющих основу сознания и поведения личности и влияющих на ее развитие. 
В философской литературе существуют разные принципы классификации и иерархии ценностей. Выделяют высшие ценности (наиболее общие для людей), такие, как смысл жизни, добро, справедливость, красота, истина, свобода и т. д. (так как именно они являются высшим уровнем отношений личности к окружающему миру и регулятором ее поведения и деятельности) и ценности-средства, подчиненные высшим ценностям, обусловленные человеческой практикой, потребностями и интересами людей.

Средством формирования аксиологической системы личности выступают система знаний человека и, главным образом, его жизненный опыт, социальная практика. В смысле педагогических воздействий формирование ценностей человека происходит в процессе развития его мировоззрения, поэтому вся система воспитательной работы, нацеленная на формирование научного мировоззрения учащихся, работает и на создание их ценностных ориентаций.

Первые ответы на вопрос «что такое хорошо и что такое плохо» человек получает в младенчестве (0-6 лет), тогда же формируются его первые представления о ценностях. В детстве (6-12 лет) они складываются в основном путем подражания взрослым. Самостоятельный путь их формирования начинается в отрочестве (12-18 лет), когда учащийся сознательно усваивает многие научные абстракции, в частности, абстракцию аксиологической системы. В своей основе система складывается в период юности (18-24 года), когда происходит становление самостоятельной личности, начинается производственная профессиональная деятельность. В дальнейшем система ценностей личности продолжает развиваться под влиянием социальных условий, жизненного опыта и накапливающейся с годами мудрости.

3. Третья функция компетентности - антиципация (способность действовать с упреждением). С ней связаны функции прогнозирования и рефлексии. В деятельности человека невозможно найти такие ситуации, в которых указанные функции не играли бы существенной роли. Для индивида типичным является не только отражение настоящего, не только сохранение прошлого, но и овладение перспективой будущего, именно в этом и заключается универсальная функция антиципации. Антиципация - это способность в той или иной форме предвосхищать события. Сознание человека вообще направлено на планирование своей деятельности.

Б.Ф. Ломов и Е.Н. Сурков, приходят к такому обобщению: «Мышление - это, прежде всего, предвидение. Антиципация, базирующаяся на забегающей вперед работе мозга, представляет собой проявление познавательной активности субъекта, позволяющей в ответ на стимулы, 
действующие только в настоящем, предугадать или предвосхищать еще не наступившие события, используя накопленный в прошлом опыт, и быть готовым к встрече с ними» [9, с. 11].

Функция антиципации тесно связана с прогнозированием - процессом разработки прогнозов о состоянии какого-либо явления в будущем. Самым эффективным средством научного прогнозирования является математическое моделирование, составляющее основу восходящего к Пифагору математического естествознания. Соответственно, решение любой текстовой математической задачи - это прогноз ситуации, поэтому учитель математики постоянно занимается этим видом деятельности с детьми.

Рефлексия есть анализ самим человеком внутреннего плана своих действий, направленность его сознания на осмысление его собственных познавательных действий; она является источником нового знания. Мышление без рефлексии - это, по Гегелю, «наивное» мышление, не выходящее за рамки рассудка, который схватывает лишь отдельные стороны явления - в их раздельности. С рефлексией связано исследование природы теоретических понятий. Не случайно своей системе развивающего обучения В.В. Давыдов дал два синонимичных наименования: система развития теоретического мышления и система рефлексивного развития детей. Кроме рефлексии мышления, для самовоспитания важна рефлексия собственного поведения личности, умение оценивать свои возможности в практической деятельности.

Названные функции компетентности отражаются в системе интеллектуальных качеств личности таких, как:

- любознательность - способность активно реагировать на новую информацию;

- критичность - способность фиксировать и разрешать противоречия;

- креативность - способность разрабатывать необычные, оригинальные идеи, использовать нестандартные способы решения;

- дисциплинированность ума - способность планировать свою интеллектуальную деятельность;

- самоконтроль - способность к самопроверке;

- диалогичность - способность участвовать в совместных обсуждениях, вести диалог с самим собой.

Наличие этих интеллектуальных качеств, стимулируют развитие интеллектуальных возможностей ребенка, способствуют обогащению его интенционального (основа индивидуальных интеллектуальных склонностей) и метакогнитивного опыта.

Формирование названных интеллектуальных качеств предполагает перестройку всего ментального (умственного) опыта ребенка, 
способствующего продуктивному познавательному отношению к учебному материалу. В качестве средств развития интеллектуальных качеств личности выступают: вся система воспитательной работы; методы формирования научного мировоззрения; а также такие методические приемы, как использование в учебных текстах персонажей с четко определенными психологическими ролями, введение диалогов и гетерологов, использование специально разработанных заданий, ориентированных на актуализацию и обогащение опыта учащихся, учет выбора учащимися удобного темпа прохождения учебного материала и посильного уровня трудности заданий.

4. Четвертая группа функций компетентности - регулирование деятельности: целеполагание, планирование, программирование, проектирование, выбор методов деятельности, управление. Объекты внешнего мира, преобразованные в процессе деятельности, более адекватно отражаются в сознании человека. Деятельность находит свое выражение в активности личности и обусловлена потребностями, установками, эмоциями, целями и мотивами, которые придают ей направленность и избирательность.

Цель - особого рода образование, в котором предвосхищается потребный человеку результат его будущих действий. Цель, целеполагание - это в высшей степени интегральное, системное, личностное образование, характеризующее человека в целом и выступающее в роли определенной детерминанты деятельности человека, важнейшей составляющей которой является планирование. Именно после планирования и начинается основная работа, в результате которой может меняться глубина понимания проблем, представления о способах их решения и, как следствие, видение промежуточных и конечных целей. При этом конкретные цели, методы, способы и формы работы могут подвергаться непрерывной коррекции. Реализация целей достигается в результате совершаемых человеком действий. Чтобы любое действие было адекватно предмету, средствам и условиям, в которых оно осуществляется, необходимо их отражение в голове человека; при этом возникающее отражение выступает в роли регулятора действия.

Говоря о функции регулировании деятельности, мы имеем ввиду и интеллектуальную деятельность человека, т. е. деятельность, связанную с созданием субъективно новых идей, с использованием различных подходов к решению проблем и т. д. С интеллектуальной деятельностью неразрывно связано такое свойство как креативность - способность порождать оригинальные идеи в нерегламентированных условиях деятельности. В психологии можно найти толкование креативности в узком значении (дивергентное мышление, отличительной чертой которого 
является разнонаправленность и вариативность поиска разных, в равной мере правильных решений относительно одной и той же ситуации) и в широком смысле: творческие интеллектуальные способности привносить нечто новое в опыт; порождать оригинальные идеи; способность осознавать пробелы и противоречия, фомулировать гипотезы относительно недостающих элементов ситуации; а также способность отказываться от стереотипных способов мышления.

В качестве критериев креативности можно рассматривать такие свойства интеллектуальной деятельности, как беглость (количество идей в единицу времени); оригинальность (способность производить «редкие» идеи, отличающиеся от общепринятых, типичных ответов); восприимчивость (чувствительность к необычным деталям, противоречиям; готовность гибко и быстро переключаться с одной идеи на другую); метафоричность (готовность работать в иносказательном контексте, склонность использовать ассоциативные средства для выражения своих мыслей, а также умение в простом видеть сложное и, наоборот, в сложном - простое). Функция креативности характеризует реальные творческие достижения человека в его обыденной и профессиональной деятельности.

Рассмотренные функции компетентности реализуются системой умений и навыков индивида. Под умением понимается способность эффективно выполнять действие в соответствии с целями и условиями, в которых приходится действовать, и использовать ранее полученные опыт и знания. Качества умений определяются характером и содержанием знаний о выполненном действии. Умения неразрывно связаны с навыками - действиями, характеризующимися высокой мерой освоения, - и совершенствуются по мере овладения навыками. Высокий уровень умений означает возможность пользоваться различными навыками для достижения одной и той же цели в зависимости от условий действия. Приобретенные человеком умения и навыки не только определяют качество его деятельности и обогащают его опыт, но и выступают свидетельством уровня общего умственного развития человека, качеств его ума. Легкость и быстрота овладения знаниями, умениями и навыками говорит о высоком уровне способностей данного человека.

Система умений и навыков определяет следующие качества: умение мыслить эмпирически, теоретически, логически, алгоритмически, образно, комбинаторно, интуитивно, пространственно, геометрически, креативно, диалектически; средством формирования их является опыт. Опыт в широком смысле есть единство знаний и умений; соотносится с категорией практики как результат деятельности людей, включающий 
совокупность исторически сложившихся умений и знаний. Для компетентного человека определяющим является ментальный (умственный) опыт, состав и строение которого определяют

- когнитивный опыт, обеспечивающий хранение, упорядочение, трансформацию и переработку наличной и поступающей информации;

- метакогнитивный опыт, позволяющий осуществлять непроизвольное и произвольное управление собственной интеллектуальной деятельностью, саморегуляцию процессов переработки информации;

- интенциональный опыт, определяющий интеллектуальные склонности субъекта (выбор конкретной предметной области, направления поиска решения, предпочтение источников информации и т. д.)

Если говорить о формировании умений и навыков в процессе школьного обучения, то следует заметить, что такое управляемое обучение способствует формированию навыков с желательными, заданными свойствами и таких их качеств, как обобщенность действия, лабильность, гибкость и вместе с тем устойчивость результата. Вместе с формированием полноценоценных навыков происходит формирование собственно познавательных мотивов учащихся.

5. Пятая функция компетентности - саморегулирование, представляет один из уровней регуляции активности и является информационным процессом, носителями которого выступают различные психические формы отражения действительности. Общие закономерности функции саморегуляции реализуются в индивидуальной форме, которая зависит от конкретных условий, а также от характеристик нервной деятельности, от личных качеств субъекта и его привычек в организации своих действий, что формируется в процессе воспитания.

Эта функция реализуется системой нравственных качеств личности. Мораль (нравственность) - один из основных способов нормативной регуляции действий человека в обществе; особая форма общественного сознания и вид общественных отношений. Мораль регулирует поведение и сознание человека во всех сферах общественной жизни - в труде, быту, политике, науке, в семейных, личных, внутригрупповых, межклассовых и международных отношениях, а также его отношение с природой. Таким образом, нравственность конкретного человека есть освоенная, внутренне принятая общественная мораль, регулирующая его индивидуальное поведение, опирающаяся на мировоззренческие убеждения и чувство совести. Сердцевиной человеческой нравственности является нравственное чувство, переживания, совесть.

Важнейшими компонентами нравственного сознания и поведения являются нравственная потребность и воля, желание, настойчивость, 
умение реализовать нравственный выбор в жизни. Убежденность, согласие с собственной совестью и волевая твердость обеспечивают в совокупности возможность подлинно нравственного поступка. Еще одним компонентом нравственного сознания и поведения являются нравственные навыки и привычки, которые возникают и закрепляются в нервной системе субъекта как итог всей совокупности нравственных отношений и поведения. Наступает такое состояние привычного нравственного сознания и поведения, когда безнравственные поступки становятся невозможными, а нравственное поведение становится привычным, обыденным, не нуждающимся в контроле.

Степень восприятия индивидом нравственного сознания и культуры общества определяет нравственную культуру личности, характеризующуюся такими качествами, как:

- культура этического мышления (умение пользоваться этическим знанием, различать добро и зло, применять нравственные нормы к особенностям сложившейся ситуации и т. д.);

- культура чувств (способность человека к сочувствию, сопереживанию);

- культура поведения (регулирует форму, манеры поведения личности в обществе).

Высший уровень нравственной культуры личности - «нравственная мудрость», т. е. способность обеспечить оптимальность и гарантию нравственной деятельности, готовность к достойным поступкам в любых жизненных ситуациях.

Нравственная культура личности формируется под воздействием разнообразных факторов: жизненного опыта и воспитания (в целом и, в частности, в результате нравственного воспитания), этического просвещения и искусства.

Человек культуры - свободная личность, способная к самоопределению в мире культуры. Е.В. Бондаревская [1] говорит, что, с педагогической точки зрения, это означает воспитание у учащихся таких взаимосвязанных качеств, как высокий уровень самосознания, чувство собственного достоинства, самоуважение, самостоятельность, самодисциплина, независимость суждений, сочетаемая с уважением к мнению других людей, способность к ориентировке в мире духовных ценностей и в ситуациях окружающей жизни, умение принимать решения и нести ответственность за свои поступки, осуществлять свободный выбор содержания своей жизнедеятельности, линии поведения, способов своего развития. Человек культуры - гуманная личность. Гуманность - вершина нравственности, так как в ней любовь к людям, ко всему живому сочетается с милосердием, добротой, способностью к сопереживанию, 
альтруизмом, готовностью оказывать помощь, пониманием ценности и неповторимости каждого человека, стремление к миру, согласию, добрососедству, умением проявлять терпимость и доброжелательность ко всем людям. Педагогические аспекты воспитания этих качеств состоят в необходимости всесторонней гуманитаризации содержания образования, гуманизации его методов и всей системы воспитательных отношений.

6. Шестая функция компетентности - адаптация - способность субъекта приспосабливаться к различным условиям внешней среды. Она затрагивает все уровни организма: от молекулярного до психологической регуляции деятельности.

Функция адаптации реализуется в системе психических качеств индивида (эмоций, чувств, памяти, внимания, воображения и т. д.) Психическое отражение реальной действительности происходит при взаимодействии с ней субъекта, но деятельность субъекта не сводится при этом только к физиологическим процессам в организме, а принимает форму сознания и определяется, прежде всего, социальными отношениями. Кроме того, в человеке происходят и неосознанные психические явления, которые тоже выполняют функцию адаптации индивида к природной и социальной среде.

Свойства психических качеств вскрывает и изучает психология. Структуры психики человека образуют единую систему и проявляются как свойства его психического склада:

- темперамент, демонстрирующий особенности психической деятельности индивида, включая его эмоциональность;

- характер - склад душевной жизни человека, который проявляется в его психической жизни, привычках, складе ума;

- психические способности (индивидуальные качества человека, которые выступают условием успешной деятельности); к ним относят различия в эффективности основных видов деятельности (научные способности, артистические, писательские, технические, математические и др.) и в проявлении работы органов чувств, а также высшей нервной деятельности; наличие исключительных способностей характеризуется такими понятиями, как гениальность, талант;

- интеллектуальные способности: познавательный стиль (различие между людьми при выборе ими способов изучения действительности); когнитивный стиль (различие в индивидуальных средствах переработки информации); интеллектуальный стиль (различие в способах постановки и решения проблем); особенности индивидуальной картины мира и т. д.

Средством формирования названных структур является воспитательная работа, направленная на сохранение психического здоровья, 
на воспитание чувств, воли, эмоций, характера и т. д. Развитие психики человека в процессе воспитания и обучения изучает педагогическая психология (за рубежом - психопедагогика). Психические качества складываются и развиваются, в первую очередь, под воздействием социальной среды. На их развитие в процессе обучения есть две противоположных точки зрения психологов: натуралистическая (способности являются врожденными и мало поддаются изменению в учебном процессе) и социальная (врожденные качества несущественны; например, согласно А.Н. Леонтьеву, все они имеют прижизненное происхождение; все зависит от педагога, «нет плохих учеников, есть плохие учителя»). Хотя советская психология придерживалась в основном второй точки зрения, которая и послужила теоретической основой «развивающего обучения», истина, видимо, как всегда, посередине.

Другим результативным средством воспитания психических способностей является специально выстроенный целенаправленный учебно-воспитательный процесс, включающий педагогические воздействия по всем направлениям воспитательной работы. Например, много исследований посвящено влиянию искусства на этот процесс, в частности, создания положительных эмоций. Древние греки называли сущность эстетического переживания (чувство очищения, освобождения, гармонии, порядка) словом катарсис. Искусство переплавляет избыток эмоций в более высокое качество чувств. Л.С. Выготский писал, что искусство - «сильнейшее средство для наиболее целесообразных и важных разрядов нервной энергии» [2, с. 271].

7. Седьмая функция компетентности - интеграционная - реализуется в системе мировоззренческих взглядов, представлений и убеждений. Это главная функция компетентности, которая интегрирует в себе все рассмотренные выше функции и включает

- результативность деятельности;

- самосознание - осознание человеком самого себя как члена общества, своих взаимоотношений с окружающим миром, другими людьми, своих действий и поступков, мыслей и чувств, всего многообразия качеств личности;

- самовоспитание - системная и сознательная деятельность человека, направленная на выработку и совершенствование своих положительных качеств и преодоление отрицательных; результат самовоспитания проверяется практикой жизни, той ролью, которую оно играет в совершенствовании личности;

- саморазвитие; 
- самообразование - образование, приобретаемое вне учебного заведения путем самостоятельной работы;

- саморегуляцию.

Эта функция определяет содержание компетентности в целом и характеризуется всеми структурами ее подсистем:

- системой знаний человека;

- системой ценностей;

- системой интеллектуальных качеств;

- системой умений и навыков;

- системой нравственных качеств;

- системой мировоззренческих взглядов, убеждений, идеалов.

Свойства этих подсистем выявлены выше. Средства формирования их также названы: это развитие всей системы компетентности. Среди этих подсистем нельзя выделить главную, основную. Тем не менее, роль стержня, определяющего ориентацию личности, играет мировоззренческая система. Мировоззрение, по своей сути, интегрирует социальные, нравственные, эстетические отношения и выступает в качестве определяющего фактора личностного развития и формирования человека. К важнейшим функциям мировоззрения относятся:

- информационно-отражательная, связанная с определенным способом восприятия явлений и событий окружающего мира и их отражением в сознании человека;

- ориентационно-регулятивная, которая определяет поведение и деятельность человека, его сознание;

- оценочная, суть которой заключается в том, что все явления окружающей жизни человек оценивает, исходя из своих взглядов и убеждений.

В педагогике понятие мировоззрения трактуется так: «Под мировоззрением следует понимать специфическую форму сознания человека, включающую в себя обобщенную систему его знаний, взглядов, убеждений и идеалов, в которых выражается его отношение к развитию природы и общества и которые определяют его общественно-политическую и нравственно-эстетическую позицию, и поведение в различных сферах жизни» [22, с. 411].

Особую роль в формировании научного мировоззрения играет школа, где в содержании образования и воспитания заложена система знаний и идей, отражающая вопросы развития природы, общества, человеческого сознания. Важнейшей предпосылкой формирования научного мировоззрения является глубокое и прочное овладение знаниями: чтобы в состоянии выражать свое отношение к явлениям действительности, оценивать их, быть в чем-то убежденным, необходимо иметь знания. 
Чем осмысленнее и прочнее знания, тем обстоятельнее ученик анализирует факты, глубже проникает его мысль в сущность научных понятий, законов, идей. Одновременно нужна специальная система воспитательной работы, направленная на перевод знаний в личностные взгляды и убеждения. Этому способствуют следующие условия:

1. Обеспечение глубокой научной доказательности, логической убедительности, непротиворечивости всех усваиваемых выводов мировоззренческого характера.

2. Придание обучению общественной направленности.

3. Соблюдение принципа историзма при изучении программного материала.

4. Развитие познавательной активности и самостоятельности учащихся в процессе урочных и внеклассных занятий.

5. Возбуждение эмоционального отношения учащихся к изучаемому материалу.

6. Связь обучения с жизнью, вовлечение учащихся в активную трудовую деятельность.

7. Учет возрастных и индивидуальных особенностей учащихся в процессе учебно-воспитательной работы.

8. Личность учителя, его авторитет и общение с учащимися.

Процесс формирования научного мировоззрения школьников носит целостный и интегральный характер, начинаясь с проявления у младших школьников простейших элементов мировоззренческих представлений, которые затем с возрастом обогащаются, усложняются, закладывают основы убеждений в старших классах и завершаясь становлением мировоззрения у взрослого человека.

В современной психолого-педагогической литературе все многообразие профессиональных качеств педагога объединяется понятием профессиональной компетентности. Это не просто совокупность профессиональных знаний и умений, а »сложное индивидуально-психологическое образование на основе интеграции социально-педагогического опыта, теоретических знаний, практических умений и значимых личностных качеств, обусловливающее готовность педагога к выполнению профессиональной деятельности» (Н.Е. Костылева).

В. Сластенин, И. Исаев говорят о том, что «понятие профессиональной компетентности педагога выражает единство его теоретической и практической готовности к осуществлению педагогической деятельности и характеризует его профессионализм», и предлагают в качестве основы модели профессиональной компетентности учителя педагогические умения, объединенные в четыре группы. 
1. Умения «переводить» содержание объективного процесса воспитания в конкретные педагогические задачи: изучение личности и коллектива для определения уровня их подготовленности к активному овладению новыми знаниями и проектирование на этой основе развития коллектива и отдельных учащихся; выделение комплекса образовательных, воспитательных и развивающих задач, их конкретизация и определение доминирующей задачи.

2. Умения построить и привести в движение логически завершенную педагогическую систему: комплексное планирование образовательно-воспитательных задач; обоснованный отбор содержания образовательного процесса; оптимальный выбор форм, методов и средств его организации.

3. Умения выделять и устанавливать взаимосвязи между компонентами и факторами воспитания, приводить их в действие: создание необходимых условий (материальных, морально-психологических, организационных, гигиенических и др.); активизация личности школьника, развитие его деятельности, превращающей его из объекта в субъект воспитания; организация и развитие совместной деятельности; обеспечение связи школы со средой, регулирование внешних непрограммируемых воздействий.

4. Умения учета и оценки результатов педагогической деятельности: самоанализ и анализ образовательного процесса и результатов деятельности учителя; определение нового комплекса доминирующих и подчиненных педагогических задач [19].

С.А. Дружилов предлагает выделять «следующие компоненты профессиональной компетентности педагога: мотивационно-волевой, функциональный, коммуникативный и рефлексивный.

Мотивационно-волевой компонент включает в себя: мотивы, цели, потребности, ценностные установки, стимулирует творческое проявление личности в профессии; предполагает наличие интереса к профессиональной деятельности.

Функциональный (от лат. functio - исполнение) компонент в общем случае проявляется в виде знаний о способах педагогической деятельности, необходимых учителю для проектирования и реализации той или иной педагогической технологии.

Коммуникативный (от лат. соттипісо - связываю, общаюсь) компонент компетентности включает умения ясно и четко излагать мысли, убеждать, аргументировать, строить доказательства, анализировать, высказывать суждения, передавать рациональную и эмоциональную информацию, устанавливать межличностные связи, 
согласовывать свои действия с действиями коллег, выбирать оптимальный стиль общения в различных деловых ситуациях, организовывать и поддерживать диалог.

Рефлексивный (от позднелат. reflexio - обращение назад) компонент проявляется в умении сознательно контролировать результаты своей деятельности и уровень собственного развития, личностных достижений; сформированность таких качеств и свойств, как креативность, инициативность, нацеленность на сотрудничество, сотворчество, склонность к самоанализу. Рефлексивный компонент является регулятором личностных достижений, поиска личностных смыслов в общении с людьми, самоуправления, а также побудителем самопознания, профессионального роста, совершенствования мастерства, смыслотворческой деятельности и формирования индивидуального стиля работы» [5].

Следует отметить, что профессиональная компетентность является необходимой составляющей профессионализма учителя. Понятие «профессионализм» является более широким, чем понятие «профессиональная компетентность». Быть профессионалом - это не только знать, как делать, но и уметь эти знания реализовывать, добиваясь необходимого результата. То есть при оценке профессионализма речь должна идти об эффективности профессиональной деятельности [4].

На основании проведенных исследований, Дружилов и Хашина делают вывод, что «деятельность сотрудников, не приобретших необходимого профессионализма, но вынужденных выполнять работу в условиях нормальных профессиональных требований, имеет для них стрессогенный характер, а их индивидуальный потенциал ориентирован не на развитие, а лишь на адаптацию. При этом «экстремальный» характер ситуаций определяется не внешними факторами среды, а неготовностью «внутренних» средств субъекта труда. С другой стороны, обнаружено, что учителя, видящие смысл своей деятельности, более ориентированные не на витальные, а на экзистенциальные ценности, легче преодолевают профессиональные затруднения; они эффективнее адаптируются к изменяющимся условиям труда, в большей степени нацелены на саморазвитие [6].

Становление профессионализма педагога тесно связано с формированием профессионального самосознания, в основе которого лежит общее понятие самосознания, формированию которого следует уделять внимание уже в период школьного обучения. 


\section{2. Новые требования к профессиональной деятельности учителя начальных классов в условиях современных инновационных процессов}

На современном этапе модернизации российского образования одним из приоритетных направлений государственной политики в данной сфере является развитие системы непрерывного профессионального образования, повышения его качества. Внимание со стороны руководителей образования к вопросу подготовки педагогических кадров обусловлено тем, что именно учитель реализует стоящие сегодня перед образованием задачи, а значит, именно от его готовности - психологической, технологической, нравственной - зависит успех или неуспех проводимых реформ, реализация ФГОС НОО.

В настоящее время существует противоречие между спросом на кадры, способные реализовать современные образовательные цели, и предложением со стороны специализированных учреждений педагогического образования.

Основной причиной указанного противоречия является стремление преподавателей реализовать современные цели образования в рамках традиционной системы организации учебного процесса, т. е. в режиме передачи «готового» знания.

В связи с этим актуальным остается вопрос повышения профессионального уровня и компетентности педагогов к реализации требований Стандарта, к инновационным процессам, происходящим в современной школе.

Инновационными направлениями сегодня становятся: новые подходы к организации образовательной среды; новые требования к результатам освоения ООП, структуре программ и условиям их исполнения; новое качество образования; интеграция дисциплин, урочной и внеурочной деятельности, основного и дополнительного образования; приоритет личностного развития младшего школьника; создание условий для полноценной учебной деятельности, которая обеспечивает сохранение любознательности ребенка, его активности и развитие умений познавать мир.

Инновационная деятельность учителя, по мнению В. Сластенина, это «социально-педагогический феномен, отражающий его творческий потенциал, выход за пределы нормативной деятельности» [19].

Реализация системно-деятельностного подхода, новые требования к организации образовательного пространства существенно меняют роль и место самого педагога.

Можно выделить три роли современного учителя:

1. Учитель-профессионал - учитель, имеющий теоретические знания, обладающий системой профессиональных умений, готовый и способный 
обеспечивать необходимые условия, успешно осуществлять основные педагогические функции при обучении младших школьников. Учитель, который демонстрирует культурные образцы действий, инициирует пробные учебные действия учащихся, консультирует, корректирует действия, ищет способы включения в работу каждого ребенка.

2. Уиитель-воспитатель - учитель-»партнер», умело создающий условия для приобретения детьми жизненного опыта, самостоятельной выработки жизненных ценностей, умеющий бесконфликтно общаться в процессе обучения. Организация субъект-субъектного общения, позволяет учить ребенка свободно вести конструктивный диалог, слушать и слышать собеседника, формировать информационную культуру - используя различные источники знаний получать необходимую информацию и анализировать ее. Использование педагогом групповых форм обучения способствует развитию у детей умения сотрудничать, ответственного поведения, саморегуляции.

3. Педагогическая поддержка предполагает оказание адресной помощи ребенку, не избавление его от проблемной ситуации, но содействие в ее преодолении. Каждый ребенок при любых условиях (даже самых неблагоприятных) имеет стартовый интеллектуальный капитал. Каждый ребенок объективно нуждается в создании определенных условий благоприятствующих развитию его интеллектуальных возможностей. Каждый ребенок имеет право на полноценное развитие в условиях качественного школьного образования. Личностный подход к обучению предполагает бережное отношение к личности ученика. Современный учитель должен уметь работать одновременно с разными детьми, принимая их разный исходный уровень готовности к обучению, разный склад ума, разное отношение к учебе и выстраивая специальную образовательную линию для каждого конкретного ребенка с учетом его индивидуальных интеллектуальных и личностных особенностей. Важно, чтобы педагог умел подчеркивать достижения и успехи ребенка, а при необходимости мог оказать педагогическую поддержку каждому нуждающемуся ученику [13, с. 5].

Но насколько учитель готов к переменам в сфере образования? Осознает их значимость и свою миссию в этом? Эти и другие подобные вопросы волнуют сегодня педагогическую общественность. От готовности педагога во многом зависит успех реализации Стандарта.

Так что же определяет готовность учителя? В качестве составляющих здесь можно выделить, во-первых, личностную, в том числе и психологическую, готовность. Понимание необходимости грядущих изменений в образовании, принятие этих изменений на личностно-значимом уровне - основа успешной профессиональной деятельности. До тех пор пока 
педагог сердцем не примет нововведения, не поймет, что это дает для ребенка и общества в целом, ничего хорошего не получится. Всегда найдется масса причин, которые будут оправдывать нежелание работать поновому: планировать урок, вести контрольно-оценочную деятельность учебных достижений младших школьников, уделять внимание личностным и метапредметным результатам на ряду с предметными и пр. И наоборот, принятие учителем всех нововведений, связанных с реализацией стандарта, открывает массу возможностей для профессионального роста, творческой педагогической деятельности, совершенствованию педагогического мастерства по решению профессиональных задач.

Во-вторых, организационная составляющая готовности педагога. Здесь речь идет скорее о самоорганизации, умении организовать свою деятельность, включая деятельность по изучению материалов ФГОС, организацию повышения своего профессионализма, курсовую подготовку и выполнение определенных заданий в качестве обучающегося.

В-третьих, теоретическая готовность. Знание ФГОС НОО его особенностей, нормативных документов, связанных с его введением, новых СанПин, ФЗ «Об образовании в РФ» и пр. позволяет быть в курсе изменений, происходящих в образовании, по-новому взглянуть на собственную педагогическую деятельность, оценить свою возможность и готовность к работе в новых условиях.

Говоря о теоретической готовности учителя, нельзя не сказать о предметной составляющей. Учитель начальной школы полипредметен. Он преподает и русский язык, и математику, и окружающий мир и ряд других предметов, что вызывает определенную трудность в качественной подготовке к урокам. К сожалению, можно констатировать факт снижения филологической, математической компетентности учителей первой ступени. Надо заметить, что учительские ошибки в определении основных понятий, например, курса математики, что не допустимы. Ведь переучивать всегда труднее, нежели сразу грамотно формировать понятие. В этой ситуации необходимо обязательно пользоваться хорошей справочной литературой.

В-четвертых, технологическая составляющая готовности учителя. В основе Стандарта лежит системно-деятельностный подход (основы которого были еще заложены в работах психологов Л.С. Выготского, Д.Б. Эльконина, В.В. Давыдова), предполагающий:

- воспитание и развитие качеств личности, отвечающих требованиям информационного общества, инновационной экономики;

- переход к стратегии социального проектирования и конструирования в системе образования на основе разработки содержания и технологий 
образования, определяющих пути и способы достижения социально желаемого уровня (результата) личностного и познавательного развития обучающихся;

- ориентацию на результаты образования как системообразующий компонент стандарта, где развитие личности обучающегося на основе усвоения универсальных учебных действий, познания и освоения мира составляет цель и основной результат образования;

- признание решаюшей роли содержания образования, способов организации образовательной деятельности и взаимодействия участников образовательного процесса в достижении целей личностного, социального и познавательного развития обучающихся;

- учет индивидуальных возрастных, психологических и физиологических особенностей обучающихся, роли и значения видов деятельности и форм общения для определения целей образования и воспитания и путей их достижения;

- гарантированность достижения планируемых результатов освоения основной образовательной программы начального общего образования, что и создает основу для самостоятельного успешного усвоения обучающимися новых знаний, умений, компетенций, видов и способов деятельности [20, с. 3].

Системно-деятельностный подход предполагает использование в процессе обучения образовательных технологий деятельностного типа. Это обучение на основе «учебных ситуаций», проектная, исследовательская деятельность школьников, информационные и коммуникационные технологии, уровневая дифференциация, игровые технологии, технология развития критического мышления и т. п.

Реализация системно-деятельностного подхода требует от учителя:

- набора определенных личностных качеств, таких как вера в возможности ученика, интерес к внутреннему миру учащегося, открытость к принятию других позиций, точек зрения, общую культуру, эмоциональную устойчивость, позитивное отношение к профессии;

- способности ставить педагогические цели и мотивировать учебную деятельность, умения перевести тему урока в педагогическую задачу и сделать ее личностно значимой для младших школьников, обеспечивать успех деятельности для всех, умения критериального оценивания;

- компетентности: педагогической, психологической, предметной, методической, ИКТ.

Образовательная задача учителя состоит в организации условий провоцирующих детское действие, так как между обучением и психическим развитием человека всегда стоит его деятельность. Способы организации 
образовательной деятельности, взаимодействие участников образовательного процесса во многом зависят от позиции учителя. Готовность слушать учащихся, вести диалог, направлять, помогать осваивать новое знание, консультировать - новая позиция Учителя в учебном процессе. На современном уроке главными действующими лицами становятся ученики. Дети должны иметь возможность импровизировать, выбирать свой путь исследования. Мастерство учителя заключается в том, чтобы качественно подготовить урок, продумать динамику видов деятельности, возможные учебные ситуации и создать условия, чтобы дети самостоятельно совершали открытия. В связи с этим учителю необходимо переориентировать свою деятельность со «знания» на «понимание». Поменять учебную парадигму «знание - умение - навык» на «знание - понимание - компетентность».

Использование деятельностных технологий влечет за собой изменение урока как основной формы обучения школьников. Изменяются его структура, целевые установки, подходы к отбору содержания и определению основных видов деятельности младших школьников. И сегодня должно измениться представление учителя об уроке. Современный урок гораздо шире предметного обучения. Учитель не только преподает предмет (математику, русский язык или любой другой), а использует его как средство для развития ребенка, его познавательных интересов, регулятивных умений, коммуникативных навыков.

При планировании урока педагог должен учитывать, что

- ученик - это субъект учебной деятельности (имеет право на открытие);

- динамичность структуры урока;

- поддержку инициативы ученика в нужном направлении и обеспечение приоритета его деятельности (индивидуальные образовательные маршруты);

- разнообразие источников знания (слово учителя, современные средства коммуникации, самостоятельное наблюдение, учебное пособие или книга, Интернет и пр.);

- организацию целеполагания (помимо привычного целеполагания, на передний план выходит цель индивидуальной или коллективной деятельности);

- критериальное оценивание (критерии, по которым оценивается деятельность ученика, определяются заранее совместно с учащимися). Критериальная основа оценки требует изменения педагогического инструментария. Приоритетными в диагностике становятся не репродуктивные задания (на воспроизведение информации), а продуктивные 
задания (задачи) по применению знаний и умений, предполагающие создание учеником в ходе решения своего информационного продукта: вывода, оценки и т. п.

Так что же такое современный урок?

Это увертюра к познавательной деятельности, установка на успех; улыбка друзей и учителя, вход в науку, в культуру.

Это работа разума, режим поиска, риск гипотез, установка на результат, руководство к действию.

Это очарование новизной, озарение, обобщение сделанного и понятого, возможность говорить о чем-то с позиции знающего человека.

Это концентрация на рефлексии, багаже урока, который каждый собрал для себя.

Возвращаясь к компонентам готовности, следует отметить и методическую грамотность учителя: владение последними достижениями методической науки преподаваемых дисциплин; способность выявлять изменения в содержании учебных предметов, выбирать УМК, максимально ориентированный на достижение планируемых результатов согласно Стандарта; готовность использовать многообразие педагогического и методического инструментария для обеспечения личностных, метапредметных и предметных результатов.

Критерием готовности учителя является и его ИКT-комnетентность, которая включает умение использовать общепользовательские инструменты (текстовый редактор, редактор презентаций, динамические таблицы, базы данных), мультимедийные информационные источники, инструменты коммуникации (электронная почта, Интернет), ИКТ-средства (интерактивная доска, цифровое и мультимедийное учебное оборудование). Эффективное применение средств информатизации и информационных технологий в педагогической деятельности - это проявление педагогического мастерства учителя.

Таким образом, профессиональное мастерство учителя определяется его умением проектировать учебный процесс исходя из результатов, запланированных на данном этапе обучения, организовывать работу учащихся, их проектную и исследовательскую деятельность, осуществлять оценочную деятельность на критериальной основе.

Новые требования, предъявляемые к учителю, сформулированы и в профессиональном стандарте педагога. В данном нормативном документе [17] декларируется необходимость наполнения профессионального стандарта учителя новыми компетенциями, причем профессиональные компетенции педагога, отражающие специфику работы в начальной 
школе, объединены в отдельную часть. В Стандарте говорится, что педагог начальной школы должен:

1. Учитывать своеобразие социальной ситуации развития первоклассника в связи с переходом ведущей деятельности от игровой к учебной, целенаправленно формировать у детей социальную позицию ученика.

2. Обеспечивать развитие умения учиться (универсальных учебных действий) до уровня, необходимого для обучения в основной школе.

3. Обеспечивать при организации учебной деятельности достижение метапредметных образовательных результатов как важнейших новообразований младшего школьного возраста.

4. Нести ответственность за личностные образовательные результаты своих учеников.

5. Учитывать при оценке успехов и возможностей учеников неравномерность индивидуального психического развития детей младшего школьного возраста, а также своеобразие динамики развития учебной деятельности мальчиков и девочек [17, часть 4].

А содержание методической составляющей профессиональной компетентности учителей начальной школы должны составлять:

1. Организация информационной основы деятельности учителя и ученика: целеполагание (предметное личностное), реализация оптимальных приемов и различных моделей представления, объяснения и интерпретации изучаемых объектов; оценивание; организация индивидуальной работы с учащимися с учетом их интересов и способностей, умение выстраивать коррекционную работу по преодолению основных затруднений и типичных ошибок учащихся начальной школы при обучении математике;

2. Ориентация на поддержку познавательной самостоятельности учащихся: раскрытие личностного смысла учения; знание основных затруднений и типичных ошибок учащихся начальной школы при обучении математике и умение выявлять их в ходе учебного процесса и при итоговой оценке результатов обучения;

3. Эффективное использования средств обучения: понимание особенностей учебной задачи и способов деятельности при ее решении; владение методикой работы с заданиями, имеющими альтернативные решения, включая анализ различных способов решения и обоснование наиболее рационального способа.

Реализация системно-деятельностного подхода, в рамках которого обогащается метальный опыт учащихся, формируется система знаний и умений, требует от учителя переориентации своей деятельности со знания на понимание; смены общеизвестной учебной парадигмы 
знание-умение-навык на другую: знание-понимание-компетентность; учебный диалог должен стать не только основным способом освоения предметных знаний и умений, но и основной формой формирования ключевой компетенции - умение учиться.

Становится очевидным, что без построения новой системы повышения квалификации педагогов невозможно обеспечить инновационные процессы, реализуемые в ФГОС.

\section{3. Система подготовки учителей начальных классов к реализации новых образовательных стандартов}

Одним из основных направлений государственной политики в сфере образования является развитие системы непрерывного профессионального образования, повышения его качества.

В Приоритетных направлениях развития образовательной системы РФ отмечается, что решение проблемы подготовки педагогических кадров, адекватной современному социальному заказу, «требует энергичных и неординарных мер» (Фурсенко А.А. Доклад на заседании Правительства РФ 9 декабря 2004 г., с. 16).

Очевидно, что такое внимание со стороны руководителей образования к вопросу подготовки педагогических кадров обусловлено, прежде всего, тем, что именно учитель реализует стоящие сегодня перед образованием задачи, а значит, именно от его готовности - психологической, теоретической, технологической, нравственной, организационной - зависит успех или неуспех проводимых реформ. В связи с этим модель профессиональной подготовки должна включать несколько направлений:

1) курсы повышения квалификации учителей начальной школы;

2) систему методических семинаров по актуальным проблемам начального образования;

3) педагогическое проектирование;

4) мониторинг и диагностику профессионального мастерства педагога.

Остановимся более детально на перечисленных направлениях.

Курсы повышения квалификации учителей одна из наиболее распространенных и хорошо известных форм организации деятельности учителей по освоению новых подходов в сфере образования и формирования профессиональных качеств.

Тематика курсов и их объем могут быть различны. Однако содержание должно быть максимально ориентировано на освоение инновационных подходов и профессиональных компетенций, необходимых для реализации ФГОС. 
Рассмотрим в качестве примера подходы к организации и тематику курсовой подготовки педагогов г. Перми и Пермского края. Всего было разработано 9 программ (на 72 часа каждая) профессиональной подготовки учителей начальных классов.

Научно-методологической основой дополнительных профессиональных программ повышения квалификации педагогических работников являются:

- культурно-исторический системно-деятельностный подход, разрабатываемый в трудах отечественных психологов Л.С. Выготского, А.Н. Леонтьева, П.Я. Гальперина, Д.Б. Эльконина и др., раскрывающий основные психологические условия и механизмы процесса усвоения знаний, формирования картины мира, общую структуру учебной деятельности учащихся;

- учение о структуре и динамике психологического возраста (Л.С. Выготский) и периодизация психического развития ребёнка, определяющая возрастные психологические особенности развития личности и познания (Д.Б. Эльконин);

- психологическая теория деятельности и развития личности (Б.Г. Ананьев, Л.И. Божович, А.Н. Леонтьев, С.Л. Рубинштейн и др.);

- теоретические подходы к индивидуализации, гуманизации и личностной ориентации образования (А.Н. Алексеев, Ш.А. Амонашвили, В.В. Давыдов, А.А. Леонтьев, В.В. Рубцов, Л.В. Трубайчук, И.С. Якиманская и др.);

- теоретические основы развивающего обучения (В.В. Давыдов, Д.Б. Эльконин, Л.В. Занков и др.);

- теория учебной деятельности (Ю.К. Бабанский, В.В. Давыдов, Л.В. Занков, В.В. Репкин, Д.Б. Эльконин и др.);

- теория мотивации, ценностной ориентации, самоорганизации, саморазвития и самореализации личности (В.И. Андреев, Д.Н. Богоявленский, Е.В. Бондаревская, А.В. Кирьякова и др.);

- исследования рефлексии в учебной деятельности учащихся (А.Б. Воронцов, В.В. Давыдов, Н.Я. Сайгушев и др.);

- теоретические подходы педагогики сотрудничества (Ш.А. Амонашвили, Г.А. Цукерман и др.);

- теории формирования и развития универсальных учебных действий (А.Г. Асмолов, Г.В. Бурменская, И.А. Володарская, О.А. Карабанова и др.); - социологическая теория деятельности (Г.П. Щедровицкий, О.С. Анисимов);

- технология деятельностного метода «Школа 2000...» (Л.Г. Петерсон).

Следует заметить, что если в 2011, 2012 гг. актуальными и востребованными были программы «ФГОС НОО как система требований», 
«Теоретико-методологические основы реализации ФГОС НОО», то в 2013, 2014 гг. популярными, вызывающими профессиональный интерес стали программы: «Формирование и мониторинг метапредметных результатов в начальной школе»; «Современный урок. Реализация системно-деятельностного подхода. Анализ современного урока в соответствии с ФГОС НОО»; «Диагностика и формирование универсальных учебных действий в начальной школе»; «Технологии оценивания универсальных учебных действий»; «Новые подходы к проектированию уроков по ФГОС».

Переход от преобладания теоретической составляющей курсовой подготовки, трансляции идей стандарта к практико-ориентированной направленности очевиден.

Например, выбор темы «Формирование и мониторинг метапредметных результатов в начальной школе» может быть обусловлен введением метапредметного подхода в образовании, который требует нового осмысления содержания образования, методов и форм организации учебного процесса и роли учителя в этом процессе. Необходимо понимание, что метапредметный подход в образовании (Ю.В. Громыко, А.В. Хуторской) - попытка осторожно, постепенно, без всяких резких революционных реформ развернуть образование навстречу новым потребностям и новым вызовам, вызовам XXI века. В отличие от Нового времени XXI век характеризуется возникновением комплексных проблем, решение которых предполагает в первую очередь междисциплинарное взаимодействие. XXI век - век рефлексивных форм знания. Это время, когда мало быть погруженным в »свой» предмет, необходимо знать особенности его устройства, прорывные зоны развития и методы конфигурирования с другими типами знаний. Любой учитель начальной школы должен быть еще хотя бы немножко метапредметником. Здесь без освоения метапредметного подхода в образовании, который строится как раз на рефлексии разных форм знания и методов работы с ними, не обойтись [11].

Метапредметный подход - это, прежде всего, очень хорошее знание преподаваемых предметов, что, собственно, и позволяет деятельностно пересобирать учебный материал и заново его интерпретировать с точки зрения деятельностных единиц содержания. Метапредметный подход, по мнению А.В. Хуторского, не предполагает отказ от предметной формы, но, напротив, предполагает развитие ее на рефлексивных основаниях [11]. Реализация метапредметного подхода в образовании способствует достижению тех метапредметных результатов, которые заданы ФГОС НОO. 
В основе научно-методологической базы лежат следующие теории и положения:

1. В современной педагогике существуют три взгляда на метапредметность в образовании (А.Г. Асмолов, д.пс.н., А.В. Хуторской, д.п.н., Ю.В. Громыко, д.ф.н.).

2. Метапредметы могут быть представлены в двух формах: как «связки» между предметами и как отдельные учебные курсы.

3. В основе метапредметного подхода положение: знания об объектах не сообщаются ученику в виде готового материала, а добываются каждым учеником.

4. Метапредметная деятельность - это универсальная деятельность, которая является «надпредметной».

5. Метапредметное содержание образования - деятельность, обеспечивающая процесс обучения в рамках любого учебного предмета.

6. Метапредметное содержание занятия - деятельностные единицы, носящие универсальный характер: понятия, модели, схемы, задачи, проблемы и пр.; системная работа со способом.

7. Метапредметные результаты (по А. Асмолову) включают освоенные обучающимися универсальные учебные действия (познавательные, регулятивные и коммуникативные), обеспечивающие овладение ключевыми компетенциями, составляющими основу умения учиться.

8. Профессиональный стандарт педагога - документ, включающий перечень профессиональных и личностных требований к учителю, действующий на всей территории Российской Федерации.

Учитель начальной школы с первых дней обучения формирует у школьников «умение учиться», которое предполагает полноценное освоение всех компонентов учебной деятельности (познавательные и учебные мотивы; учебная цель; учебная задача; учебные действия и операции) и выступает существенным фактором повышения эффективности освоения учащимися предметных знаний, умений и формирования компетенций, образа мира и ценностно-смысловых оснований личностного морального выбора.

Важнейшей задачей современной системы образования является формирование совокупности «универсальных учебных действий», так как они обеспечивают возможность каждому ученику самостоятельно осуществлять деятельность учения, ставить учебные цели, искать и использовать необходимые средства и способы их достижения, уметь контролировать и оценивать учебную деятельность и ее результаты. Они создают условия развития личности и ее самореализации.

Таким образом, под универсальными учебными действиями понимается совокупность способов действия учащего, обеспечивающих 
самостоятельное усвоение новых знаний, формирование умений, включая организацию учебного процесса (т.е. умение учиться) (по А. Асмолову). Освоенные способы осуществления деятельности могут быть применимы как в рамках образовательного процесса, так и при решении проблем в реальных жизненных ситуациях. Обладая универсальными учебными действиями, учащийся не только решает учебно-познавательные и учебно-практические задачи, но и осознает способы действия, которые он применил.

Сами по себе УУД не есть готовый продукт, а есть результата управления их развитием через учебную деятельность. Тогда возникают вопросы, а как развивать названные группы УУД? И только ли УУД составляют содержание метапредметных результатов?

Формирование УУД предполагает понимание процесса формирования умственных действий. Согласно теории планомерного, поэтапного формирования умственных действий и понятий П.Я. Гальперина предметом формирования должны стать действия, понимаемые как способы решения определенного класса задач. Для этого необходимо выделить и построить такую систему условий, учет которых не только обеспечивает, но даже и »вынуждает» ученика действовать правильно и только правильно, в требуемой форме и с заданными показателями. Эта система включает три подсистемы:

1) условия, обеспечивающие построение и правильное выполнение учеником нового способа действия;

2) условия, обеспечивающие «отработку», т. е. воспитание желаемых свойств способа действия;

3) условия, позволяющие уверенно и полноценно переносить выполнение действий из внешней предметной формы в умственный план [21].

Основное назначение первой подсистемы условий заключается в том, чтобы раскрыть перед учеником объективную структуру материала и действия; выделить в материале ориентиры, а в действии последовательность его отдельных звеньев - систему объективных условий, позволяющих ученику с первого раза и каждый следующий раз правильно выполнять все задания. Эта система условий, обеспечивающих правильное выполнение нового действия, в теории получила название схемы ориентировочной основы действия. Она включает в себя: характеристику и функции продукта (результата), содержание и операциональный состав действия; характеристику материала, орудий и средств действия, в том числе и средств контроля.

Вторая подсистема - это описание условий, обеспечивающих приобретение действием желаемых свойств, форму выполнения действия 
(материальная/материализованная, речевая, умственная), полноту или сокращенность действия; меру дифференцировки, меру отделения существенных свойств от несущественных, временные и силовые характеристики, а также разумность, сознательность, обобщенность, критичность и освоенность действия.

Третья подсистема условий обеспечивает перенос действия в идеальный (умственный) план в ходе поэтапных преобразований, происходящих с действием в процессе его становления. Выделены шесть этапов интериоризации действия.

На первом этапе усвоение начинается с создания мотивационной основы действия, когда закладывается отношение ученика к целям и задачам усваиваемого действия, к содержанию материала, на котором оно отрабатывается. Это отношение может в последующем измениться, но роль первоначальной мотивации для усвоения очень велика.

На втором этапе происходит становление схемы ориентировочной основы действия, т. е. системы ориентиров, необходимых для выполнения действия с требуемыми качествами. В ходе освоения действия эта схема постоянно проверяется и уточняется.

На третьем этапе происходит формирование действия в материальной (материализованной) форме, когда ориентировка и исполнение действия осуществляются с опорой на внешне представленные компоненты схемы ориентировочной основы действия.

Четвертый этап - внешнеречевой. Здесь происходит преобразование действия - вместо опоры на внешне представленные средства ученик переходит к описанию значений этих средств и действий во внешней речи. Необходимость материального (материализованного) представления схемы ориентировочной основы действия, как и материальной формы действия, отпадает; ее содержание полностью отражается в речи, которая и начинает выступать в качестве основной опоры для становящегося действия.

На пятом этапе (действие во внешней речи «про себя») происходит дальнейшее преобразование действия - постепенное сокращение внешней, звуковой стороны речи, основное же содержание действия переносится во внутренний, умственный план.

На шестом этапе действие совершается в скрытой речи и приобретает форму собственно умственного действия.

П.Я. Гальперин подчеркивал, что эмпирически формирование действия, понятия или образа может проходить с пропуском некоторых этапов данной шкалы; причем в ряде случаев такой пропуск является психологически вполне оправданным, так как учащийся в своем прошлом 
опыте уже овладел соответствующими формами и в состоянии успешно включить их в текущий процесс формирования (действия с предметами или их заместителями, речевые формы и т. д.). Вместе с тем П.Я. Гальперин обращал внимание на то, что суть не в поэтапности, а в полной системе условий, позволяющей однозначно определить и ход процесса, и его результат.

Для реализации требований ФГОС, формирования УУД младших школьников учитель начальных классов должен обладать высокой профессиональной компетентностью: психолого-педагогические знания должны стать основой профессионального умения создавать условия для формирования у учащегося универсальных учебных действий. Целенаправленность и эффективность этого процесса обусловлена профессиональным мастерством учителя: умением определять цели своей деятельности, владением педагогическими технологиями, умением выбирать оптимальные формы и методы обучения, умением объективно оценивать учебные достижения учеников, используя современные технологии и инструменты оценивания.

Обладая свойством универсальности учебные действия и метапредметные результаты в целом, имеют психологическое содержание, поэтому не могут быть измерены с помощи простых средств (опроса, контрольной работы и пр.). Для этого требуется интегративный критерий, учитывающий психологический аспект метапредметности.

Смена образовательной парадигмы отражается не только на изменении содержания образования и методов обучения, но и на структуре, формах, методах оценки учебных достижений, содержании контрольнооценочных средств. В связи с этим проблема оценки и оценочной деятельности приобретает особую актуальность.

Система оценки - сложная и многофункциональная система, включающая как текущую, так и итоговую оценку результатов деятельности младших школьников; как оценку деятельности педагогов и школы, так и оценку результатов деятельности системы образования.

С введением Федеральных государственных образовательных стандартов начального общего образования меняются концептуальные подходы к системе оценивания учебных достижений младших школьников. Совершенствование системы начального образования зависит от того, как устроена система оценки: насколько она поддерживает и стимулирует учащихся; насколько точную обратную связь она обеспечивает; насколько включает учащихся в самостоятельную оценочную деятельность; насколько она информативна для управления системой образования. 
Место, роль и функции системы оценки достижения требований к образовательным результатам, ее особенности определяются основными подходами к пониманию и формированию стандартов общего образования. Предметом стандартизации в образовательных стандартах первого поколения выступали обязательный минимум содержания основных образовательных программ и требования к уровню подготовки выпускников. Это определяло и основное направление системы оценки - оценку уровня освоения выпускниками обязательного минимума. Новые стандарты устанавливают в качестве своего ведущего компонента Требования к результатам освоения основных образовательных программ, которые определяются на основе общественного договора между личностью, обществом и государством и подразумевают тем самым распределение ответственности за достигаемые результаты между всеми участниками договора.

Оценка как средство обеспечения качества образования предполагает вовлеченность в оценочную деятельность не только педагогов, но и самих учащихся. Оценка на единой критериальной основе, формирование навыков рефлексии, самоанализа, самоконтроля, само и взаимооценки дают возможность учащимся не только освоить эффективные средства управления своей учебной деятельностью, но и способствуют развитию самосознания, готовности открыто выражать и отстаивать свою позицию, развитию готовности к самостоятельным поступкам и действиям, принятию ответственности за их результаты.

Универсальные, или метапредметные, умения становятся важнейшим компонентом содержания образования. Основным объектом оценки метапредметных результатов служит сформированность ряда регулятивных, коммуникативных и познавательных универсальных действий. Основное содержание оценки метапредметных результатов в начальной школе строится вокруг умения учиться, т. е. той совокупности способов действий, которая, обеспечивает способность обучающихся к самостоятельному усвоению новых знаний и умений, включая организацию этого процесса.

Особенности оценки метапредметных результатов связаны с природой универсальных действий. В силу своей природы, являясь функционально по сути, ориентировочными действиями, метапредметные действия составляют психологическую основу и являются решающим условием успешности решения учащимися предметных задач. Соответственно, уровень сформированности универсальных учебных действий, представляющих содержание и объект оценки метапредметных результатов, может быть качественно оценен и измерен в таких основных формах, как специально сконструированных диагностические задачи, 
учебные и учебно-практические задачи, проверочные задания по математике, русскому языку, литературному чтению, окружающему миру, технологии и другим предметам проверочные задания, требующие совместной (командной) работы учащихся на общий результат, комплексные задания на межпредметной основе. Таким образом, оценка метапредметных результатов может проводиться в ходе различных процедур. Эти процедуры должны быть освоены учителями начальных классов.

Обобщая выше изложенное можно сделать вывод, что профессиональные программы повышения квалификации педагогических работников «Формирование и мониторинг метапредметных результатов в начальной школе», "Диагностика и формирование универсальных учебных действий в начальной школе», «Технологии оценивания универсальных учебных действий» позволяют учителям более детально разобраться в сущности новых для них понятий, новых метапредметных результатах, механизмах их формирования, мониторинга и оценки, что подтверждает их актуальность, новизну и обоснованность в реализации.

Поскольку основной формой обучения в начальной школе является урок, то все инновационные процессы затрагивают, прежде всего, именно этот компонент дидактической системы, что обусловило повышение интереса педагогов к профессиональным программам повышения квалификации «Современный урок. Реализация системно-деятельностного подхода. Анализ современного урока в соответствии с ФГОС НОО» $и$ «овые подходы к проектированию уроков по ФГОС».

В начальной школе, в соответствии с ФГОС, основными результатами должны стать предметные, метапредметные и личностные результаты. Выпускники начальной школы должны научиться использовать знаковосимволические средства, овладеть всеми типами учебных действий, включая способность принимать и сохранять учебную цель и задачу, планировать ее реализацию, контролировать и оценивать свои действия, вносить соответствующие коррективы в их выполнение, научиться строить умозаключения и принимать решения на основе самостоятельно полученной информации, а также приобрести первичный опыт критического отношения к получаемой информации, сопоставляя ее с информацией из других источников и имеющимся жизненным опытом.

Очевидно, что нужен инструмент, который позволит формировать требуемые образовательные результаты. Новые подходы к обучению, ориентированные на приоритеты развития личности учащихся и формирования у них надпредметных умений, начали разрабатываться в отечественной педагогике в 60-х годах прошлого века. На теоретических основаниях психологической теории деятельности (Л.С. Выготский, 
А.Н. Леонтьев, П.Я. Гальперин) появились системы развивающего обучения Л.В. Занкова, Д.Б. Эльконина - В.В. Давыдова. В 70-е годы активно разрабатывалась технология проблемного, чуть позже - проблемно-диалогического обучения. Таким образом, в последние полвека в российской педагогике и образовательной практике накоплен обширный опыт активизации деятельности учащихся, который помог осознать всем участникам образовательного процесса роль самостоятельный учебных действий учеников для их последующего успешного обучения. С другой стороны, сама жизнь, которая требует от каждого человека умения делать свой собственный выбор, принимать решения и нести за них ответственность, самостоятельно искать пути и способы решения своих профессиональных и жизненных проблем, ориентироваться в потоке информации осваивать новые технологии, подводит учителей к переоценке своего опыта учения и обучения, понимания и принятия новых целей образования, механизмов их достижения.

Значительно изменились сущностные характеристики урока, а, значит, изменились и подходы к его проектированию. Термин «проектирование» не является традиционным для педагогов. Наряду с новыми методическими понятиями «конструирование» и »сценирование» урока он пришел на смену привычному всем «планированию».

Проектирование (от лат. projectus, буквально - брошенный вперед) процесс создания продукта, прототипа, прообраза предполагаемого или возможного объекта, состояния. Дидактическое проектирование - это мысленное предвосхищение учителем процесса обучения и его результатов. Педагогическое проектирование - предварительная разработка основных деталей предстоящей деятельности у учащихся и педагога на уроке, прогнозирование её результатов.

Таким образом, появление в профессиональном языке термина «проектирование» отражает те изменения, которые происходят сегодня в деятельности учителя при подготовке урока, реализующего требования ФГОС:

- осуществление целеполагания не как обозначение ориентиров в собственной обучающей деятельности, а как определение результатов образования ребенка (результатоориентированные цели в виде системы универсальных учебных действий);

- переход от определения (планирования) последовательности своей собственной деятельности к продумыванию совместной деятельности учителя и ученика;

- смена собственной позиции обучающего-информирующего на позицию создающего условия (образовательную среду) для учения, т. е. освоения и присвоения содержания образования ребенком. 
Таким образом, новые подходы к проектированию урока требуют от учителя постоянного совершенствования, самоанализа и корректировки своей деятельности.

K особенностям реализации всех перечисленных программ можно отнести их практико-ориентированный характер, что позволяет организовывать деятельность слушателей по выполнению различных заданий и обеспечивает совершенствование профессиональных компетенций педагога, отражающих специфику работы в начальной школе в новых, изменившихся условиях, таких как:

- умение проектировать и сценировать уроки различной целевой направленности в рамках современных образовательных технологиях;

- умение обеспечить достижение не только предметных, но и метапредметных результатов обучения (сформированных универсальных учебных действий);

- умение проводить анализ и самоанализ уроков в аспекте требований системно-деятельностного подхода.

- умение обеспечить развитие универсальных учебных действий до уровня, необходимого для обучения в основной школе;

- умение при организации учебной деятельности обеспечивать достижение метапредметных образовательных результатов как важнейших новообразований младшего школьного возраста;

- умение организовать мониторинг и диагностику метапредметных результатов, подбирать и/или составлять задания с учетом критериев их сформированности.

Очевидно, что одной курсовой подготовки педагогов к реализации ФГОС недостаточно. Нужен комплекс мероприятий, направленный на методическое сопровождение, оказание консультативной помощи по актуальным вопросам, возникающим в процессе профессиональной деятельности. Здесь большая роль отводится системе научно-практических семинаров, которые должны функционировать в течение всего учебного года и их тематика определяется запросами образовательных организаций или самих учителей.

Практика научно-методического сопровождения учителей Пермского края по введению ФГОС НОО позволила определить стратегические направления деятельности администрации учреждений и педагогов начальной школы, а также определить взаимодействие с профессорско-преподавательским составом факультета педагогики и методики начального образования Пермского государственного гуманитарно-педагогического университета. 
За последние два года сложилась определенная система семинаров:

- Планирование и проведение занятий в начальных классах с использованием комплектов по робототехнике.

- Проектирование современного урока: от целеполагания до достижения образовательных результатов.

- Организация проектно-исследовательской деятельности младших школьников в условиях реализации ФГОС НОО. Этапы работы над проектом.

- Структура самоанализа и анализа современного урока в контексте реализации ФГОС НОО.

- Развитие профессиональной компетентности учителя начальных классов в процессе реализации ФГОС НОО.

- Диагностика и формирование универсальных учебных действий в начальной школе.

- Урок английского языка в начальной школе как условие формирования УУД.

- Курс ОРКСЭ: теоретико-методические основы и опыт реализации.

- Методика и практика проектирования метапредметного урока (Открытый урок - открытый учитель - новое качество образования).

Отметим, что объем семинаров составляет 24 часа, включает как аудиторную (16 час), так и дистанционную части (8 час). Тематика, время, место проведения семинаров, известны заранее, учителя имеют право выбирать любое направление и их количество. По выполнению программы семинара каждый участник получает сертификат установленного образца.

Ключевая роль в решении проблем, преодолении рисков и затруднений отводится созданию педагогического сообщества, ориентированного на освоение ФГОС второго поколения. Мониторинг качества и результатов этих процессов в реальной педагогической практике, обобщение опыта и разработка рекомендаций может обеспечить более успешное включение всех учителей г. Перми и Пермского края в реализацию ФГОС. Этим и определяется актуальность создания в 2010 году лаборатории «ФГОС: проблемы, поиск решения, деятельность - диалог на пути к успеху».

Лаборатория «ФГОС: проблемы, поиск решения, деятельность диалог на пути к успеху» - это пространство профессиональной коммуникации и роста компетентности педагогов в условиях внедрения стандартов второго поколения, создающая условия для последовательного движения учителей и младших школьников вперёд и вверх, по «лестнице успеха». Работа лаборатории строится на основе интеграции 
научно-методической составляющей и практико-ориентированной деятельности педагогических мастерских.

Экспериментальная работа основывается на принципах системнодеятельностного и интегрированного подходов: осуществление интеграции общего и дополнительного образования, координация усилий всего педагогического коллектива, укрепление межпредметных связей, единство урочной и внеурочной деятельности, обеспечение индивидуализации обучения с учётом личностных потребностей и возможностей детей.

К результатам работы лаборатории можно отнести: разработку и апробацию вариативных моделей внедрения ФГОС НОО, методических рекомендаций по разработке образовательных программ и возможным институциональным моделям внедрения ФГОС НОО, отбор и сертифицирование тьюторов, обеспечивающих методическое сопровождение процесса внедрения стандартов нового поколения в начальную школу, разработку диагностических материалов для выявления уровня сформированности у младших школьников предметных и метапредметных результатов.

А также проведение однодневных семинаров на базе образовательных организаций по обмену опытом реализации ФГОС, тематика которых достаточно широка. В качестве примера приведем темы 2011-2012 года: «Включение младших школьников в проектную деятельность. Образовательный модуль «Первый раз в первый класс!», «Формирование УУД при работе с текстом. Сквозная линия «Чтение и работа с информацией», «Технологии формирования позиции: «Младший школьник - субъект учебной деятельности».

В рамках лаборатории были успешно разработаны и защищены проекты: «Современные формы организации учебной деятельности младших школьников (занятия, экскурсии, проекты и пр.)», «Продуктивные задания при работе с различными видами текстов как средство формирования УУД», «Роль учебных ситуаций в формировании субъектной позиции младших школьников».

\section{4. Некоторые подходы к организации мониторинга профессиональной компетентности учителей начальных классов}

Оценка эффективности всех инновационных процессов в школе в условиях реализации ФГОС НОО, определение перспективы развития образовательной организации предполагает создание оптимального механизма для выявления результатов работы всех субъектов образовательного процесса. Одним из таких механизмов является внутришкольный мониторинг. Именно мониторинг позволяет судить о состоянии школьного образования в любой момент времени, обеспечивая прогноз его 
развития. Без специального отслеживания учебно-воспитательного процесса по единой методике трудно представить корректность действий учителя в сравнении с другими учителями и успешность усвоения предмета учащимися, а опора только на накопление отметок при отсутствии четкого понимания, что такое отметка, не позволяет объективно оценивать деятельность, как учителя, так и ученика. Необходимы общий подход к разработке контрольно-измерительных материалов, единые формы контроля за ходом учебного процесса и усвоением учащимися учебного материала, согласованные критерии оценки каждого вида деятельности. Четко продуманная и выстроенная система сбора, обработки, хранения и распространения информации способствует организации эффективного управления процессами, происходящими в образовании школы, района, края.

Понятие «мониторинг» происходит от лат. monitor - напоминающий, надзирающий. Первоначально данный термин активно использовался в экологии и обозначал наблюдение, оценку и прогнозирование состояния окружающей среды в связи с хозяйственной деятельностью человека. В последнее время данный термин приобрел более широкий смысл. Этим термином обозначается постоянное наблюдение за какимлибо процессом с целью выявления его соответствия желаемому результату или первоначальным предположениям.

Мониторинг трактуется как процесс отслеживания состояния объекта (системы или сложного явления) с помощью непрерывного или периодически повторяющегося сбора данных, представляющих совокупность определенных ключевых показателей (Э.Ф. Зеер). Мониторинг необходим, когда в построении какого-либо процесса важно постоянно отслеживать происходящие в реальной предметной среде явления с тем, чтобы включать результаты текущих наблюдений в процесс управления.

В связи с этим мониторинг имеет ряд отличительных особенностей. Во-первых, он представляет собой целостную систему, реализующую множество функций. Во-вторых, в отличие от других близких или похожих педагогических и психологических понятий мониторинг обладает следующими особенностями:

1) непрерывностью, так как сбор данных происходит постоянно;

2) диагностичностью, то есть соотнесение реального состояния отслеживаемого объекта, системы или процесса с разработанной моделью или критериями;

3) информационной оперативностью и информативностью, при этом критерии для отслеживания включают наиболее проблемные показатели, на основании которых можно делать вывод об искажениях в отслеживаемых процессах; 
4) обратной связью, которая позволяет вносить коррективы в отслеживаемый процесс;

5) научностью, потому что предполагает применение обоснованных моделей и отслеживание параметров.

Для оценки состояния и прогнозирования изучаемого процесса достаточно использовать определенный ограниченный информационный набор, при этом такой набор оказывается достаточным как для фиксации состояния системы, так и для обеспечения ее динамичного контролирования и прогноза в приемлемых границах точности (И.А. Кривобоков).

В качестве объектов мониторинга могут выступать:

- профессионально-образовательный процесс;

- учебные достижения учащихся (предметные, метапредметные и личностные результаты);

- учебная деятельность младших школьников;

- развитие личности ученика;

- становление учебной группы;

- профессиональная деятельность преподавателя;

- профессиональная компетентность учителя;

- становление педагогического коллектива [13, с. 6].

В зависимости от выбранного объекта мониторинга определяются специфические цели и задачи, связанные с реализацией мониторинга на практике, т. е. в каждом случае осуществляется определенный вид мониторинга.

В системе образовательного мониторинга можно выделить несколько видов:

- персональный, это наблюдение, фиксирование динамики развития каждого учащегося и коллектива в целом; персональный мониторинг осуществляется педагогом;

- внутришкольный (внутренний), это отслеживание динамики развития коллективов, параллелей и школы в целом по определенным критериям или комплексно по нескольким направлениям и во времени; внутренний мониторинг осуществляется администрацией образовательного учреждения;

- муниципальный или региональный (внешний), это отслеживание динамики развития образовательных учреждений; внешний мониторинг осуществляется органами управления образования района, города, края.

О.В. Шабалина и М.А. Худякова, высказывают мысль о том, что ключевыми звеньями модели внутреннего мониторинга должны стать мониторинг достижений учащихся, мониторинг профессиональной компетентности учителя и мониторинг образовательного процесса [13, с. 12]. 
Краткая характеристика каждого направления.

1. Мониторинг достижений учащихся предполагает выявление уровня сформированности метапредметных и предметных результатов учеников. Он представляет собой непрерывные контролирующие действия в системе «учитель - ученик», которые позволяют наблюдать и корректировать продвижение младших школьников к запланированным результатам.

Особенностью содержания современного начального образования является нацеленность на достижение предметных (математических, языковых, литературоведческих, естественнонаучных) умений и универсальных учебных действий (коммуникативных, познавательных, регулятивных), обеспечивающих способность к организации самостоятельной учебной деятельности. Для диагностики сформированности этих умений разрабатываются измерительные материалы для каждой параллели начальных классов. Достижение результатов проверяется с помощью учебно-познавательных и учебно-практических задач базового и повышенного уровней, построенных на опорном учебном материале. Источником этого материала являются предметы учебного плана: математика, русский язык, литературное чтение, окружающий мир. Мониторинг предполагает три диагностических среза: входной, промежуточный, итоговый. Важной составляющей мониторинга качества результата является разработка заданий, апробация их в учебной деятельности, что позволяет не только констатировать уровень сформированности умений (предметных и метапредметных), но и системно формировать данные умения.

2. Профессиональная компетентность педагога складывается из ряда его профессиональных умений реализуемых в разных сферах деятельности. В данной модели в качестве ключевых были выделены три компетентности педагога: предметно-методическая компетентность, компетентность трансляции собственного педагогического опыта, коммуникативная компетентность.

Диагностика предметно-методической компетентности предполагает: во-первых, выявление уровня математической, лингвистической, естественнонаучной, литературоведческой и других предметных компетентностей педагога; во-вторых, определение уровня владения методикой преподавания предметов начальной школы; в-третьих, фиксацию знаний учителя о современных образовательных технологиях и умений эффективно применять их в образовательном процессе.

Диагностика компетентности в трансляции собственного педагогического опыта включает как количественные, так и качественные показатели, а именно: проведение мастер-классов, участие в конкурсах профессионального мастерства, научно-практических конференциях, 
выступление на совещаниях, публикации в различных источниках, издание учебно-методических, дидактических материалов на электронных и бумажных носителях.

Диагностика коммуникативной компетентности определяется уровнем владения устной и письменной речью самим учителем, а также умением организовать эффективное общение младших школьников в учебной деятельности.

3. Мониторинг образовательного процесса предполагает выявление уровня владения системно-деятельностным подходом, степенью использования новых образовательных технологий (в том числе информационных, оценочных) при организации учебной деятельности учащихся. В связи с этим особую значимость приобретают те методы и средства, которые способствуют отслеживанию как прогрессивных, так и регрессивных тенденций в развитии профессиональной компетентности учителя начальных классов, усиливающих положительное влияние и помогающих преодолеть негативные явления, возникающие в этом процессе, к числу которых относится педагогический мониторинг. Данный мониторинг проводится на уроке и во внеурочной деятельности.

Реализация системно-деятельностного подхода в учебной деятельности предусматривает построение урока с учетом активной субъектной роли ученика, динамичности структуры урока, разнообразия источников знания, поддержки инициативы ученика, формулирования конкретных целей индивидуальной или коллективной деятельности, критериального оценивания.

Для диагностики владения учителем системно-деятельностным подходом могут быть использованы критерии по следующим 5 направлениям:

1) реализация на учебном занятии деятельностного способа целеполагания;

2) создание на уроке условий для формирования действий планирования и оценочной самостоятельности младших школьников;

3) организация на уроке разных видов учебно-познавательной деятельности, в том числе с использованием действий конструирования, моделирования, проектирования;

4) применение критериального оценивания;

5) организация учебного диалога на уроке.

Использование новых образовательных технологий (проектной, информационной, оценочной, проблемного обучения и др.). Например, одним из эффективных способов достижения образовательных результатов каждого ученика является применение технологии формирующего оценивания. Эта технология предполагает понимание педагогом важности 
мотивированности ученика, поддерживает ориентацию на учебные цели и понимание критериев, по которым оцениваются достижения учеников, развивает у младших школьников способность к самооцениванию и обеспечивает учащихся конструктивными рекомендациями о том, как достигнуть улучшения результатов.

Разработка модели внутреннего мониторинга предполагает соблюдение определенной последовательности. Условно можно выделить следующие этапы:

\section{1. Нормативно-установочный}

На первом этапе должны быть определены цели и задачи мониторинга (учитывать, что цели должны быть актуальными, реальными, конкретными, педагогическими); основные показатели и критерии, по которым будет производиться оценка; выбраны методы и формы диагностики: (тесты, анкеты, опросники, проверочные работы, наблюдения, беседы и др.).

\section{2. Аналитико-диагностический}

На втором этапе идет организация сбора информации; количественная и качественная обработка данных; анализ результатов, полученных при обработке; выявлены достижения и проблемы; определены их причины.

\section{3. Прогностический}

На третьем этапе необходимы прогнозирование возможности развития системы мониторинга и разработка перспективных планов.

\section{4. Деятельностно-технологический}

На четвертом этапе осуществляется коррекция выявленных проблем по каждому направлению через проведение системы семинаров, круглых столов и обмена опытом учителей района.

\section{5. Итогово-диагностический (завершающий)}

На пятом этапе проводится оценка состояния каждого объекта мониторинга; сопоставление полученных результатов с первоначальными; определение эффективности проведенной работы.

Все этапы и элементы мониторинга структурно и функционально связаны между собой, они представляют единый цикл. Следует заметить, что этот цикл может наполняться в каждой образовательной организации разным содержанием. Осуществление полного цикла педагогического мониторинга способствует повышению эффективности педагогического процесса в системе «учитель-ученик».

Работа администратора, учителя и ученика при внутреннем мониторинге должна носить характер совместной аналитической деятельности, развивая прогностические умения, совершенствуя качество образования.

Для проведения внутреннего мониторинга учителей начальных классов были разработаны диагностические материалы и апробированы 
в образовательных организациях Пермского края. Анализ результатов мониторинга профессиональной компетентности учителя показал, что системно-деятельностными технологиями обучения владеют и могут поделиться опытом $-32,4 \%$ учителей, испытывают затруднения $-54,1 \%$, не владеют (нужна помощь) - 17,1\% педагогов.

Наиболее освоенными направлениями реализации системно-деятельностного подхода являются: гуманистическая позиция по отношению к каждому ребенку (50\% учителей готовы поделиться опытом), создание мотивационно-целевого пространство уроков на основе развития личностных потребностей учеников $(47,1 \%$ учителей готовы поделиться опытом), организация самоконтроля и самооценки учащимися своей деятельности в соответствии с выработанными критериями $(41,7 \%$ учителей готовы поделиться опытом).

Затруднения педагоги испытывают в следующих вопросах:. системно видеть предметный курс в иерархии внутрипредметных и межпредметных связей и отношений (76,4\% педагогов); проектировать цели курса, темы урока, исходя из личностных, метапредметных и предметных результатов (70,6\% педагогов); организовать учебное сотрудничество детей при решении учебных задач на основе демократического общения (58,8\% педагогов); организовать поисковую, проблемную, проектную деятельность детей (56,3\% педагогов).

Помощь педагогам требуется в вопросах: овладения способами организации рефлексии, аутентичными формами оценивания; осуществление самоанализа собственной педагогической деятельности с позиции достижения личностных, метапредметных и предметных результатов (37,5\% педагогов); создания мотивационно-целевого пространства уроков на основе развития личностных потребностей учеников $(23,5 \%$ педагогов); системно видеть предметный курс в иерархии внутри-предметных и межпредметных связей и отношений (11,8\% педагогов); проектировать цели курса, темы урока, исходя из личностных, метапредметных и предметных результатов (11,8\% педагогов).

В заключении следует отметить, что к показателям профессионализма учителя и его готовности к инновационным процессам можно отнести результаты олимпиад. Так в Пермском крае есть опыт организации и проведения Олимпиады учителей начальных классов Центров инновационного опыта Университетского округа ПГГПУ. В Олимпиаде приняли участие: 25 образовательных организаций (Центров инновационного опыта Университетского округа ПГГПУ, апробационные площадки ФГОС), 289 учителей начальных классов. Олимпиада состояла из 5 блоков: «Предметная компетентность» (7 заданий); «Методическая компетентность» (8 заданий); 
«Педагогическая компетентность» (5 заданий); «Метапредметные компетенции» (7 заданий); «Компетенции, позволяющие развивать метапредметные умения у младших школьников» (3 задания). Всего было представлено в Олимпиаде 30 заданий. Основной параметр оценки и рейтинга - общий процент правильных ответов на задания Олимпиады.

Выполнение заданий олимпиады показало: среднее время выполнения - 31 минута. Минимальный результат $-17 \%$; максимальный результат $=70 \%$.

Усредненные показатели по школам представлены на графике.

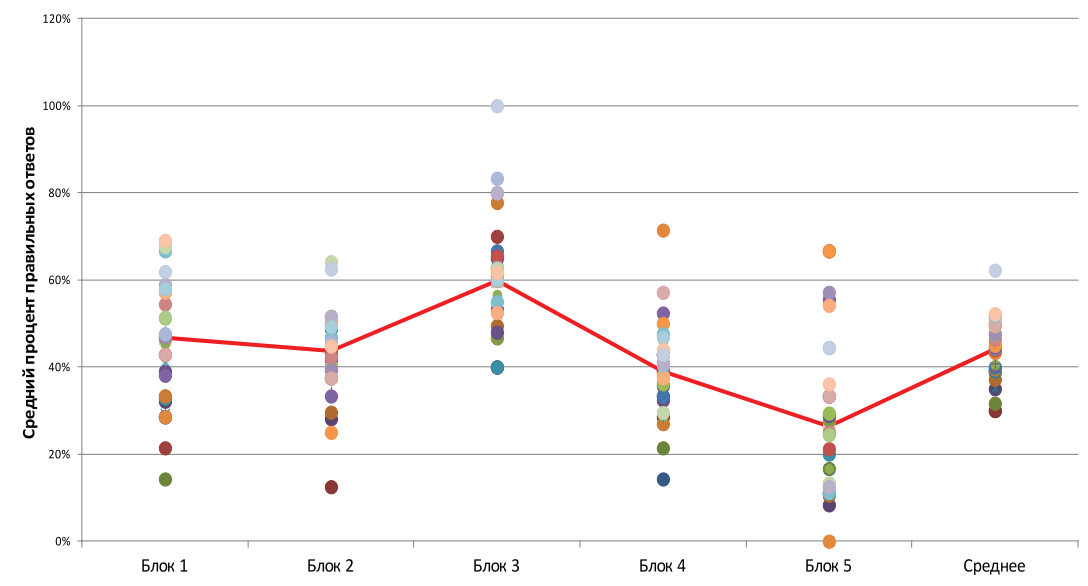

Педагоги, реализующие ФГОС НОО, отмечают, что

- изменились приемы работы на уроке: рассказ учителя превратился в обсуждение проблем, учебных или жизненных ситуаций, опрос - в собеседование, контроль - в самоконтроль и взаимоконтроль;

- особое внимание уделяется самостоятельности изучения темы;

- на уроках слышна речь ученика, который не просто повторяет за учителем заученную фразу, а анализирует изучаемые факты и делает обобщающие выводы;

- без мотивации нельзя начинать изучение новой темы. Младший школьник должен понимать, для чего, с какой целью он изучает тот или иной вопрос и как изучает: каким способом, по какому плану, какие виды деятельности для этого использует, какова перспектива урока;

- в постановке цели и выборе средств ее достижения ученик играет активную роль; 
- созданию на уроке проблемных ситуаций способствует обилие проблемных, практико-ориентированных заданий;

- ученик имеет право выбрать способ решения учебной задачи, уровень освоения, способ контроля;

- младший школьник может использовать разные стороны кодирования информации;

- учитель, проектируя урок, думает о том, чтобы дети имели возможность сделать на уроке маленькие открытия, уходили с урока с чувством победы;

- становится характерным демократический стиль отношений между учителем и учениками, отношения партнерства, умение слушать и слышать друг друга;

- учитель и учащиеся имеют возможность оценить результат совместной деятельности;

- эффективным становится прием, когда в конце урока дается проблемная задача или каверзный вопрос, которые остаются открытыми: «Вот с этого мы и начнем наш следующий урок»;

- уроки учат учиться.

Таким образом, описанная система взаимодействия с педагогами позволяет сделать вывод о системном подходе к вопросу повышения их профессиональной компетентности, отвечающей инновационным процессам реализации ФГОС.

\section{Библиографический список:}

1. Бондаревская Е.Б. Ценностные основания личностно ориентированного воспитания // Педагогика. - 1995. - № 4. - С. 29-36.

2. Выготский Л.С. Педагогическая психология. - М.: Педагогика Пресс, 1996. - 504 с.

3. Гершунский Б.С. Философия образования для XXI века. М.: Совершенство, 1998. - 608 с.

4. Дружилов С.А. Психологические проблемы формирования профессионализма и профессиональной культуры специалиста. Новокузнецк: ИПК, 2000. - 127 с.

5. Дружилов С.А. Психология профессионализма: Инженерно-психологический подход. - Харьков: Издательский дом «Гуманитарный центр», 2011. - 296 с., библ. 425 наименован. - ISBN 978-966-8324-74-1.

6. Дружилов С.А., Хашина Д.В. Сформированность концептуальной модели деятельности как условие профессиональной адаптации педагога. В кн.: А.А. Макареня, Н.Н. Суртаева, С.В. Кривых (Ред.), Реализация концепции российского образования в педагогической практике. Часть 3. СПб.: Институт образования взрослых РАО, 2005. - С. 87-91. 
7. Дидактика средней школы / Под ред. М.Н. Скаткина. - М.: Просвещение, 1982. - 319 с.

8. Зорина Л.Я. Системность - качество знаний. - М.: Знание, 1976. $-64 \mathrm{c}$.

9. Ломов Б.Ф., Сурков Е.Н. Антиципация в структуре деятельности. - М.: Наука, 1980. - 279 с.

10. Маланин В.В., Утробин И.С. О некоторых теоретических основаниях совершенствования системы образования в свете современной науки // Вестник Пермского ун-та, вып. 3, Пермь, 1996. - С. 20-27.

11. Метапредметное содержание образования // Хуторской А.В. Современная дидактика. Учеб. пособие. 2-е изд., перераб. / А.В. Хуторской. - М.: Высшая школа, 2007. - С. 159-182.

12. Новейший философский словарь / Сост. А.А. Грицанов. - Мн.: Изд. В.Н. Скакун, 1998. - 896 с.

13. Новые стандарты в нестандартной школе: сборник учебно-методических материалов / ред.-сост. М.А. Худякова, О.В. Шабалина; Перм. гос. пед. ун-т. - Пермь, 2011. - 144 с.

14. Организация и проведение внутреннего мониторинга качества образования (опыт работы учителей Краснокамского муниципального района): методические рекомендации / ред.-сост. М.А. Худякова, О.В. Шабалина; Перм. гос. гум.-пед. ун-т. - Пермь, 2014. - 263 с.

15. Орлов В.В. О концепции образования Пермского университета // Вестник Пермского ун-та, вып. 3, Пермь, 1996. - С. 3-19.

16. Пуанкаре А. О науке. - М.: Наука, 1983. - 560 с.

17. Профессиональный стандарт Педагог (Педагогическая деятельность в дошкольном, начальном общем, основном общем, среднем общем образов) (Воспитатель, учитель) // Утвержден приказом Министерства труда и социальной защиты Российской Федерации от 18 октября 2013 г. № 544н.

18. Равен Дж. Педагогическое тестирование: Проблемы, заблуждения, перспективы / Пер. с англ. - М.: «Когито-Центр», 1999. - 144 с.

19. Сластенин В.А. и др. Педагогика Учеб. пособие для студ. высш. пед. учеб. заведений / В.А. Сластенин, И.Ф. Исаев, Е.Н. Шиянов; Под ред. В.А. Сластенина. - М.: Издательский центр «Академия», 2002. - 576 с.

20. Федеральный государственный образовательный стандарт: начальное общее образование. - М., 2010. - С. 3-4.

21. Фоминова А.Н., Шабанова Т.Л. Педагогическая психология: учебное пособие - М.: ФЛИНТА, 2011 - 380 с.

22. Харламов И.Ф. Педагогика: учеб пособие. - М.: Юристь, 1997. - 512 с.

23. Холодная М.А. Психология интеллекта. - М., 1997. - С. 147-362.

24. Шишков С.Е., Кальнева В.А. Мониторинг качества образования в школе. - М.: Педагогическое общество России, 1999. - 320 с. 


\section{ОГЛАВ АЕНИЕ}

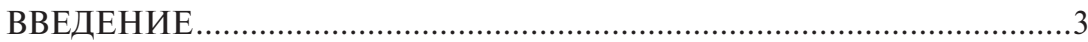

ГЛава. 1. ПРАКТИЧЕСКАЯ МЕТОДОЛОГИЯ РЕАЛИЗАЦИИ ФЕДЕРАЛЬНЫХ ГОСУДАРСТВЕННЫХ СТАНДАРТОВ .......5

Разработка и апробация инновационного инструментария оценки планируемых результатов начального общего образования в части учета региональных и этнокультурных особенностей Челябинской области

(Н.Н. Титаренко)

Экологические проекты в образовании

младшего школьника

(Е.В. Осолодкова)

Развитие и совершенствование методов

естественнонаучного образования младших школьников

(Е.В. Григорьева) .64

Решать нестандартные задачи: как этому научить

(В.В. Дрозина)

Глава 2. ПОДГОТОВКА БУДУЩИХ ПЕДАГОГОВ

К РЕАЛИЗАЦИИ ФЕДЕРАЛЬНЫХ

ГОСУДАРСТВЕННЫХ СТАНДАРТОВ

Современные технологии развития творческого потенциала будущего учителя начальных классов

(Л.Г. Махмутова).

Реализация личностных особенностей учителей

и обучающихся в образовательном процессе

(Н.А. Белоусова, Н.В. Мамылина)

Формирование культуры здорового и безопасного

образа жизни обучающихся

(Н.А. Белоусова)

ГЛава 3. ПОВЫШЕНИЕ ПРОФЕССИОНАЛЬНОЙ

КОМПЕТЕНТНОСТИ УЧИТЕЛЕЙ

НАЧАЛЬНЫХ КЛАССОВ В УСЛОВИЯХ

РЕАЛИЗАЦИИ ФГОС НОО

(М.А. Худякова) 
Белоусова Наталья Анатольевна Григорьева Евгения Витальевна Дрозина Валентина Викторовна Мамылина Наталья Владимировна Махмутова Лариса Гаптульхаевна Осолодкова Елена Владимировна Титаренко Наталья Николаевна Худякова Марина Алексеевна

\section{ПОДГОТОВКА УЧИТЕЛЕЙ И СТУДЕНТОВ \\ К ИННОВАЦИОННЫМ ПРОЦЕССАМ В РЕАЛИЗАЦИИ ФЕДЕРАЛЬНЫХ ГОСУДАРСТВЕННЫХ ОБРАЗОВАТЕЛЬНЫХ СТАНДАРТОВ}

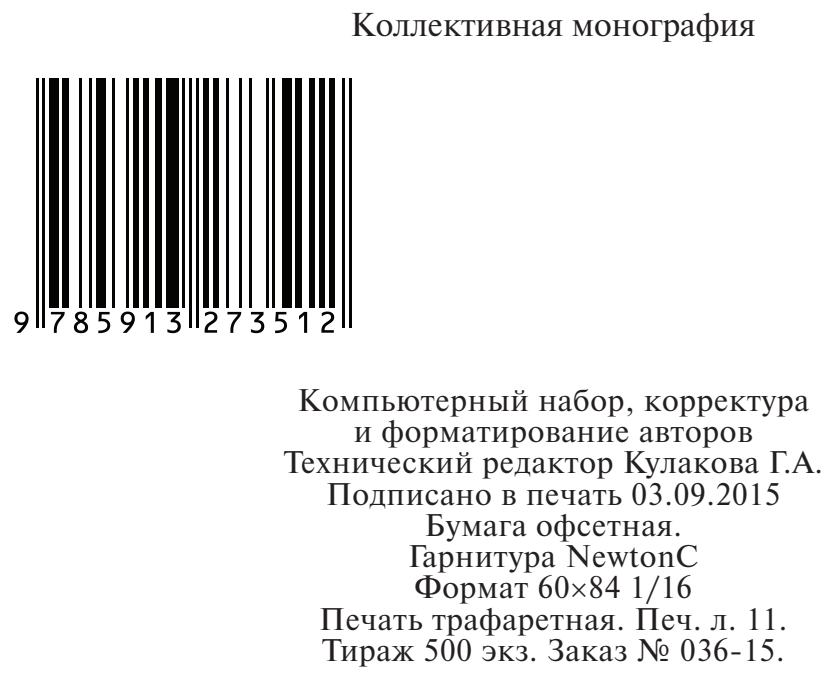

Отпечатано в типографии ИД «Академия Естествознания», 440026, г. Пенза, ул. Лермонтова, 3 